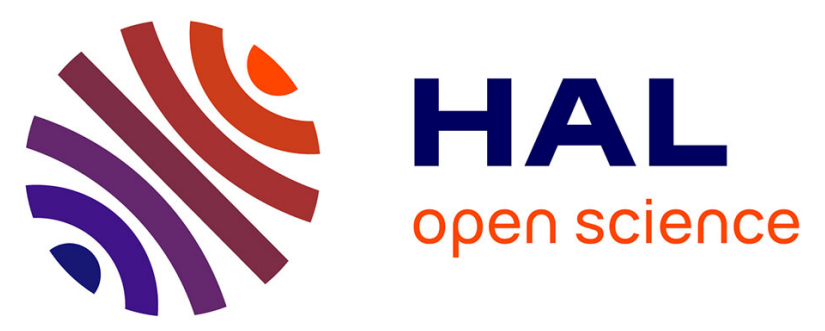

\title{
Standardized analysis of juvenile pyroclasts in comparative studies of primary magma fragmentation; 1 . Overview and workflow
}

\author{
Pierre-Simon Ross, Tobias Dürig, Pier Paolo Comida, Nathalie Lefebvre, \\ James D L White, Daniele Andronico, Simon Thivet, Julia Eychenne, Lucia \\ Gurioli
}

\section{To cite this version:}

Pierre-Simon Ross, Tobias Dürig, Pier Paolo Comida, Nathalie Lefebvre, James D L White, et al.. Standardized analysis of juvenile pyroclasts in comparative studies of primary magma fragmentation; 1. Overview and workflow. Bulletin of Volcanology, 2022, 84 (1), pp.13. 10.1007/s00445-021-01516-6 . hal-03554324

\author{
HAL Id: hal-03554324 \\ https://hal.uca.fr/hal-03554324
}

Submitted on 3 Feb 2022

HAL is a multi-disciplinary open access archive for the deposit and dissemination of scientific research documents, whether they are published or not. The documents may come from teaching and research institutions in France or abroad, or from public or private research centers.
L'archive ouverte pluridisciplinaire HAL, est destinée au dépôt et à la diffusion de documents scientifiques de niveau recherche, publiés ou non, émanant des établissements d'enseignement et de recherche français ou étrangers, des laboratoires publics ou privés. 
The following document is a pre-print version of:

Ross P-S, Durig T, Comida PP, Lefebvre N, White JDL, Andronico D, Thivet S, Eychenne J, Gurioli J (2022)

Standardized analysis of juvenile pyroclasts in comparative studies of primary magma fragmentation; 1 . Overview and workflow. Bull. Volc. 84:article 13, DOI /10.1007/s00445-021-01516-6

\title{
Standardized analysis of juvenile pyroclasts in comparative studies of primary magma fragmentation; 1. Overview and workflow
}

\author{
Pierre-Simon Ross ${ }^{1, *}$, Tobias Dürig ${ }^{2,3}$, Pier Paolo Comida ${ }^{1}$, Nathalie Lefebvre ${ }^{4}$, James D.L. White ${ }^{2}$, Daniele \\ Andronico5 $^{5}$, Simon Thivet ${ }^{6,7}$, Julia Eychenne ${ }^{6}$, Lucia Gurioli $^{6}$
}

1. Institut national de la recherche scientifique, 490 rue de la Couronne, Québec (Qc), G1K 9A9, Canada, pierresimon.ross@inrs.ca, pier_paolo.comida@inrs.ca

2. Department of Geology, University of Otago, 360 Leith Street, Dunedin 9016, New Zealand, james.white@otago.ac.nz

3. Now at Institute of Earth Sciences, University of Iceland, Sturlugata 7, 101 Reykjavík, Iceland, tobi@hi.is

4. ETH Zurich, Institute of Geochemistry and Petrology, Clausiusstrasse 25, 8092 Zurich, Switzerland, natlefebvre@hotmail.com

5. Istituto Nazionale di Geofisica e Vulcanologia, Osservatorio Etneo - Sezione di Catania, Piazza Roma, 2, 95125 Catania, Italy, daniele.andronico@ingv.it

6. Laboratoire Magmas et Volcans, Université Clermont Auvergne - CNRS - IRD, OPGC, 6 Avenue Blaise Pascal, 63170 - Aubière, France, julia.eychenne@uca.fr, lucia.gurioli@uca.fr

7. Now at Section for Mineralogy, Petrology \& Geochemistry, Department of Earth and Environmental Sciences, Ludwig-Maximilians-University Munich, Theresienstrasse 41, 80333 München, Germany, simon.thivet@min.unimuenchen.de

* Corresponding author, pierre-simon.ross@inrs.ca

\begin{abstract}
Juvenile pyroclasts, especially in the ash size range, provide important information on primary fragmentation processes, i.e. initial explosive magma fragmentation, and on the state of the magma both prior to and at the point of fragmentation and quenching. There exists an extensive body of literature focusing on the quantification of juvenile particle morphology (shape), internal textures and surface features spanning several decades, however a standardized method has yet to emerge for comparative studies. No community-wide consensus currently exists (i) regarding the most representative size fraction(s) to be examined, (ii) on sample preparation procedures (such as whether to use whole particle silhouettes or 2D cross-sections), (iii) on imaging techniques and image acquisition parameters, or (iv) on the optimal morphometric parameters to measure. Lack of a standardized method precludes robust comparison between different studies and laboratories. We propose here a preliminary "best practices" and workflow for characterization of juvenile pyroclasts, for comparative studies of primary fragmentation. If the community follows such a standardized method, it will become possible to accumulate a large volume of consistent data on juvenile pyroclasts from a range of eruption styles, fragmentation mechanisms, and magma compositions. This will ultimately allow deeper insights into the full panoply of magma-to-pyroclast processes that drive particle-producing volcanic eruptions. One or more "fragmentation diagrams" may eventually be developed to allow different types of magmatic and phreatomagmatic explosive eruptions to be distinguished based on their products.
\end{abstract}

\section{Introduction}

For unwitnessed explosive eruptions, volcanologists rely on pyroclastic deposits to reconstruct eruptive styles, modes of transport/deposition, dispersal and fragmentation processes within various volcanic contexts (e.g., Campi Flegrei caldera, Italy: Wohletz et al. 1995; Pistolesi et al. 2017; Vesuvius stratovolcano, Italy: Barberi et al. 1989; Cioni et al. 2003; Gurioli et al. 2010; Sulpizio et al. 2010; various monogenetic volcanoes: White 1991; Jordan et al. 2014, 2016; Agustín-Flores et al. 2015; Graettinger and Valentine 2017; Fitch and Fagents 2020). Even for witnessed eruptions, some aspects of eruption dynamics, such as magma ascent, vesiculation and primary fragmentation can only be reconstructed from pyroclastic deposits, with a particular focus on juvenile fragments (e.g., Dellino and La Volpe 1995; Andronico et al. 2009; Pardo et al. 2014a; Gurioli et al. 2015, 2018; Liu et al. 2017; Polacci et al. 2019; Thivet et al. 2020a, b, c). Juvenile particles are "clasts derived from the newly erupted magma" (White and 
Houghton 2006). Most juvenile clasts are glassy, although some are nearly glassy, such as tachylitic clasts formed by some basaltic eruptions (Fisher and Schmincke 1984). Juvenile clasts can be further divided into primary and recycled (Houghton and Smith 1993; White and Houghton 2006; D'Oriano et al. 2014). Recycled clasts have fallen back into the crater and have then been ejected again (D'Oriano et al. 2014). Non-juvenile fragments, often called lithics (White and Houghton 2006), are fragments "derived from rock or sediment that predates the eruption". A final type of fragment consists of 'composite' clasts which combine juvenile and nonjuvenile material (White and Houghton 2006).

Here, "primary" fragmentation is used for initial explosive magma fragmentation, as opposed to "secondary" fragmentation that can occur during transport of pyroclasts (Cashman and Scheu 2015). The focus of this paper being explosive magma fragmentation, we are not concerned with phreatic eruptions (which don't directly fragment magma), hyaloclastite formation (which is not explosive), and so on. Identifying the mechanisms of primary fragmentation (magmatic or phreatomagmatic) can be particularly contentious (e.g., Wohletz 1983a; Rausch et al. 2015; White and Valentine 2016; Schmith et al. 2017). Magmatic fragmentation has been described as "driven solely by gasses originally dissolved in the magma" and as occurring "(1) when magma ascends rapidly during explosive eruptions, (2) after rapid decompression caused by plug pressurization or collapse of volcanic edifices and lava domes, (3) by shearing of magma at the conduit walls, or (4) by impact-induced explosion of hot solid blocks during dome collapse" (Cashman and Scheu 2015). Phreatomagmatic fragmentation is a consequence of thermohydraulic fuelcoolant interaction processes between the magmatic melt and external water, which results in shockwave-generated fine ash particles and rapid melt quenching (Wohletz 1986; Büttner and Zimanowski 1998; White and Valentine 2016; Dürig et al. 2020b). Elucidating primary magma fragmentation mechanisms has important implications for understanding the hazards posed by active volcanoes, since different eruptive styles pose different ranges of hazards (e.g., Beget et al. 2005; Cioni et al. 2008a; Nemeth et al. 2012; Brand et al. 2014).

Interpretation of primary magma fragmentation mechanisms, and the state of magma at the time of fragmentation, is traditionally based on grain-size distribution, componentry, as well as the morphologies, surface features and textural characteristics of juvenile pyroclasts. The ash fraction $(\leq 2 \mathrm{~mm}$; see White and Houghton 2006 and Table 1 for definition of grain size terms) has often been preferred, since ash particles are rapidly quenched in air or water. Such characteristics have been studied for several decades (e.g., Heiken 1972, 1974; Heiken and Wohletz 1985; Cioni et al., 1992, 2008b, 2014; Dellino and La Volpe 1995; Büttner et al. 1999; Dellino et al. 2001, 2012; Taddeucci et al. 2002; Dürig et al., 2012b, 2020a, 2020b, 2020c; Ross and White 2012; Lautze et al. 2012, 2013; Jordan et al. 2014; Bagheri et al. 2015; Leibrandt and Le Pennec 2015; Liu et al. 2015a, 2015b, 2017; Avery et al. 2017; Dioguardi et al. 2017).
Many different methods have been used by different workers, with variations in terms of the size fraction(s) to be analyzed, on sample preparation including whether to use whole-particle silhouettes or 2D cross-sections, on imaging techniques and image acquisition parameters, on the optimal morphometric parameters to measure, etc. This makes comparisons between different studies and laboratories challenging, since these decisions influence the measurements. Furthermore, many studies were done on unwitnessed eruptions, rather than to document juvenile pyroclast characteristics from an unambiguously known style or fragmentation mechanism. Thus, it is not yet entirely clear how to specifically link juvenile ash characteristics (particle size, morphology, internal features such as crystals and vesicles, surface features, geochemical composition) with specific eruptive styles (Bonadonna et al. 2016) or fragmentation processes (Thivet et al. 2020c).

In order to build our understanding of primary fragmentation processes, it is essential to be able to directly compare juvenile pyroclasts from different eruptions and volcanic systems. The volcanology community must therefore converge on a standardized method for analysis of juvenile pyroclasts in comparative studies of primary magma fragmentation. This paper and its companion (Comida et al. 2022) propose a standardized workflow, and we hope that it is either adopted widely, or at least forms a basis for discussions in international workshops. When a broad community consensus has been reached, we shall rigorously sample fresh natural pyroclastic deposits from observed eruptions, and compare them with artificial pyroclasts resulting from experiments where "eruption" parameters are well constrained. Then we can measure juvenile ash characteristics with the standardized method. The community should aim to cover the whole spectrum of magma compositions, eruptive styles, and magnitudes. This would allow generation of a large database of juvenile ash characteristics, and deepen our understanding of "what juvenile pyroclasts can tell us". This could also hopefully permit the creation of diagrams that can discriminate primary fragmentation processes or eruption styles based on particle characteristics, a.k.a. "fragmentation diagrams".

\section{Overview of the workflow and target users}

The workflow proposed here prescribes steps within the stages of sample selection and preparation, and then data acquisition and analysis. The workflow has standard, recommended and optional steps.

- The standard steps are those minimally required to obtain uniform data on the grain size, basic componentry, as well as the morphologies, surface features and internal textures of juvenile pyroclasts, for comparative studies. Determining the geochemical composition of the juvenile component is also standard.

- The recommended steps yield a better understanding of each sample and produce additional information that can help discriminate 
between eruptive styles or fragmentation mechanisms.

- The optional steps produce information that complements other data from the standard and recommended steps.

Two flowcharts are presented: one with the standard steps only (Fig. 1) and one with standard and recommended steps (Fig. 2). Optional steps are not shown to avoid overcrowding the diagrams.

\section{Who should use standardized analysis of juvenile} pyroclasts?

Scientists interested by comparative studies of primary magma fragmentation should follow at least Fig. 1 (standard steps), and as much as possible of Fig. 2 (standard and recommended steps). Community adoption of common particle analysis protocols will result in a large database of standardized, directly comparable data to better understand magma fragmentation.

Workers studying specific eruptive events in detail are of course free to utilize whatever methods they think are best suited to comprehensively understand those events. But if they also follow at least the flowchart with the standard steps (and if possible, some of the recommended steps), then their data can be used in comparative studies as well, extending the relevance of their work.

Researchers from volcano observatories and civil defense agencies are under pressure to get data on current or recent eruptions out quickly, and may not be realistically able to completely follow even the Fig. 1 flowchart. However, if they have the standardized methodology in mind when they collect their samples and carry out their measurements, they can more easily make pyroclastic material available to their collaborators, who can then complete the standardized analysis.

\section{Overview of standard outputs}

The standard outputs were chosen to capture a range of relatively easily measured parameters covering magma composition, particle size, componentry, and the overall morphology, internal textures (crystals and vesicles), and surface features of juvenile particles. It is important to always use the same size fractions in future comparative studies, because particle morphologies vary as a function of grain size (e.g., Wohletz 1983a; Porritt et al. 2012; Mele et al. 2011; Leibrandt and Le Pennec 2015; Liu et al. 2015a; Avery et al. 2017; Fitch et al. 2017; Mele and Dioguardi 2018; Comida et al. 2018, 2022), and so does vesicularity (e.g., Walker 1981; Houghton and Wilson 1989; Mele et al. 2011; Eychenne and Le Pennec 2012; Gurioli et al. 2015; Liu et al. 2017; Comida et al. 2022) and componentry (e.g., Eychenne and Le Pennec 2012; Murtagh and White 2013; Eychenne et al. 2015; Liu et al. 2015b, 2017). So the standardized method must be applied to juvenile pyroclasts from specific particle size fractions.

We propose to work on three evenly spaced half- $\phi$ size fractions separated from a bulk pyroclastic sample: $5.7-$ $4 \mathrm{~mm}(-2.5$ to $-2 \phi), 0.71-0.5 \mathrm{~mm}(+0.5$ to $+1 \phi)$ and $88-$
$63 \mu \mathrm{m}(+3.5$ to $+4 \phi)\left(\phi=-\log _{2} \mathrm{D}\right.$, where $\mathrm{D}$ is the diameter in $\mathrm{mm}$ of the particle; Krumbein 1934; Table 1). The two ash fractions are included in the standard outputs, whereas the lapilli fraction is recommended. The Fig. 1 workflow starts with fieldwork and ends with the following standard outputs:

- Characterization of the geochemistry of the juvenile component of the eruption (based either on whole rock geochemistry of selected large juvenile pyroclasts, or micro-analysis of the groundmass from coarse ash, see details below);

- A grain-size distribution for each sample based on sieving;

- Basic componentry (the proportion of juvenile versus non-juvenile clasts) for both ash fractions studied;

- Scanning electron microscope (SEM) images of cross-sections (polished epoxy grain mounts) for both ash fractions;

- Measurements of morphometric parameters (i.e., non-dimensional shape descriptors), 2D crystallinity and $2 \mathrm{D}$ vesicularity, on the $0.71-0.5$ $\mathrm{mm}(+0.5$ to $+1 \phi)$ cross-section images;

- SEM images of 3D juvenile grains, to visualize their surface features and count "interactive particles" (explained below), or lack thereof, in the $88-63 \mu \mathrm{m}(+3.5$ to $+4 \phi)$ fraction;

- Measurements of morphometric parameters on silhouettes (binarized images) from the 88 $63 \mu \mathrm{m}(+3.5$ to $+4 \phi)$ fraction.

\section{Overview of recommended outputs}

The version of the workflow with standard and recommended steps adds some or all of the following outputs (Fig. 2):

- A range of density, porosity and connectivity measurements;

- A "complete" grain-size distribution for studied samples, including the fine tail where appropriate, based on a combination of methods;

- Qualitative descriptions of all whole $\phi$ size fractions under the binocular microscope;

- Basic componentry for the 5.7-4 mm (-2.5 to 2ф) fraction;

- Detailed componentry on juvenile particles, for the $5.7-4 \mathrm{~mm}(-2.5$ to $-2 \phi)$ and the $0.71-0.5 \mathrm{~mm}$ $(+0.5$ to $+1 \phi)$ fractions;

- 2D crystallinity and 2D vesicularity data on juvenile particles from the $5.7-4 \mathrm{~mm}(-2.5$ to $2 \phi)$ fraction;

- 3D morphology study on juvenile particles from the $88-63 \mu \mathrm{m}(+3.5$ to $+4 \phi)$ fraction

- 2D morphology and textural parameters on juvenile particles from the $88-63 \mu \mathrm{m}(+3.5$ to $+4 \phi$ ) fraction, based on cross-sections.

\section{Organization of the paper}

To keep the manuscript length manageable, the following sections describe only the standard steps of the methodology, i.e. those included in the Fig. 1 flowchart. The presentation broadly follows the order of the steps on the flowchart. The recommended and optional steps are 
presented in Online Resource 1. Excel templates of the typical outputs are presented in Online Resource 2.

\section{Fieldwork and pyroclastic sampling}

Fieldwork (standard)

Fieldwork or experiments are the first step to collect natural or obtain artificial juvenile particles, respectively. Detailed advice on fieldwork is beyond the scope of this paper, but we stress that a detailed geological framework is needed in order to collect representative samples (Gurioli et al. 2015). Building such a framework often means studying the pyroclastic deposits from a specific eruption at several sites. It is important to know the mode of transport (pyroclastic fall versus pyroclastic density currents, PDCs). In some cases, specific eruptive units might be targeted, perhaps to represent distinct eruptive styles. Without this field-based knowledge, any data on juvenile pyroclasts is without proper context.

Sampling pyroclastic deposits for particle size, morphologies, surface features and internal textures (standard)

All types of unconsolidated pyroclastic deposits can be sampled, with caveats. If there is a choice between fallout and PDC deposits, fallout is strongly preferred, for reasons explained below. However there is no a priori reason to expect identical fragmentation processes for different eruptive phases that lead to different transport regimes.

Fall deposits from plumes, with no secondary transport, will probably best reflect the primary fragmentation signature of the plume-forming eruption or phase, although abrasion can also take place in vents (Jones and Russell 2017). Grain morphology in fall deposits is known to change as a function of distance from vent (Saxby et al. 2020), even within the same size fraction (J. Eychenne, work in progress). Therefore, samples should ideally be taken at different distances from the vent along the dispersal axis.

It is preferable to collect samples along the dispersal axis to avoid crosswind fractionation (Carey and Sparks 1986). Depending on eruptive styles and intensities, falldeposit fields can range widely in size (Figs. 3a to 3d). Proximal, medial and distal areas can be identified (Fig. 3e) where significant variations in thickness, lithology, grain size, density, grain morphology and emplacement mechanisms are observed or inferred (Fig. 3f). Samples from a targeted eruption or phase should ideally contain the three size fractions that are being targeted, but not all need to be present at single sites. Temporal variations can also affect the deposit of a single explosive event when changes in eruptive style interact with variations in wind direction and intensity. These variations can cause stratigraphic changes through each sampling site (Fig. 3f). Houghton and Wilson (1989) and Gurioli et al. (2015) recommend that narrow stratigraphic intervals should be sampled to best represent a specific fragmentation moment. If sampling is performed along the dispersal axis at multiple sites, it is important at each site to collect from the same level in the deposit (if dealing with thick deposits/long sustained eruptions).
Deposit sampling (after the eruptive activity) is usually performed in order to collect the entire sequence of a studied eruption (Gurioli et al. 2018). Gurioli et al. (2015) also summarize advice on sampling fallout during eruptions, which can be performed when field, safety and weather conditions permit. This way of sampling is usually performed in order to collect time-resolved samples, focused on a specific eruptive phase and/or single explosion. Sampling devices can be placed inside the fallout field, at different distance from the vent. Plastic sheets (e.g. Harris et al. 2013; Colo' et al. 2020), preexisting cleaned surfaces (e.g., Andronico et al. 2009; Eychenne et al. 2012; Houghton et al. 2013) or buckets (e.g. Yoshimoto et al. 2005; Swanson et al. 2009; Bustillos et al. 2016), have been used to collect sufficient material (within known surface areas) to estimate the magnitude of the event through the mass load per unit area and to obtain a sufficient number of clasts for chemical and textural characterization. More sophisticated devises, designed especially for ash, have been used for collecting ash, but also to measure its load (Bernard 2013; Shimano et al. 2013), its grain size and terminal velocity (FreretLorgeril et al. 2019; Thivet et al. 2021).

PDC deposits are less suitable for studying primary fragmentation, for two reasons. First, primary juvenile fragments in PDCs are comminuted and smoothed during transport, as is well known for cm-sized pumice (Manga et al. 2011; Bernard and Le Pennec 2016) and in basaltic lapilli from a PDC at Etna (Andronico et al. 2018). The same effect has been documented in $0.5 \mathrm{~mm}$ clasts from Vesuvius (Mele et al. 2011). Milling experiments show that even $0.5-0.25 \mathrm{~mm}$ grains are progressively rounded during transport (Jones et al. 2016). However, in general, ash is less susceptible to shape modification than lapilli (Buckland et al. 2018). The fine to extremely fine ash (Table 1) preferentially travels as suspended load and among target particles is least susceptible to abrasion (Kuenen 1960; Jerolmack et al. 2011). The second issue with PDCs is that a portion of the fine to extremely fine ash will be generated within the current, rather than from primary magma fragmentation (Wohletz et al. 1989; Büttner et al. 2002; White and Valentine 2016), requiring the separation of 'primary' from 'secondary' particles in the sample. If eruption phases producing PDCs are under investigation, or sampling sites are limited and PDC deposits are the only option, then vent-proximal samples from dilute PDCs are preferable, because they presumably undergo less secondary fragmentation.

How much material to sample depends on the grainsize distribution of the pyroclastic deposit and the type of eruption (e.g., Strombolian/transient versus Plinian/long lasting; see Appendix in Houghton and Carey 2015) and more specifically on the abundances of the targeted size fractions within the deposit. For example, in the figure 1 flowchart, 100 juvenile grains are needed for the very fine ash fraction (explained below). If the deposit is lithicpoor, relatively fine-grained and well sorted, these grains can generally be extracted from much less than $100 \mathrm{~g}$ of material. On the other hand, for poorly sorted deposits, many kilograms of material might be needed to both 
obtain a representative grainsize distribution and to extract a sufficient amount of the three size fractions. Mosley and Tindale DS (1985) and Fitch and Fagents (2020) suggest that no individual clast should weigh $>5 \%$ of the total sample weight. For each sample, the information to be noted is listed in Online Resource 2.

Contamination from adjacent layers should be minimized during sampling. In relatively fine-grained deposits, a spade or Japanese gardening tool (Fig. 4a) can be used for cleaning the face and a knife or trowel are useful for sampling. Additional information is available from the "Checklist for tephra collection" document produced by the "Tephra 2014" workshop (Bursik et al. 2015).

\section{Geochemical analysis (standard)}

Why geochemistry is needed

Whether magma fails in a brittle or in a ductile way is determined by its rheological properties in conjunction with the deformation rate it is confronted with, i.e. the increase of stress over a certain time period (Dürig and Zimanowski 2012). Since the rheological properties are affected by magma composition, particle morphologies and textures are moderately to strongly influenced by magma geochemistry (e.g., Heiken 1972; Heiken and Wohletz 1991; Pardo et al. 2014a; Comida et al. 2017; Mele et al. 2018).

Thus, in basalts for example, magmatic fragmentation is typically a ductile process in Hawaiian eruptions (Porritt et al. 2012; Thivet et al. 2020c), whereas phreatomagmatic fragmentation of the molten fuelcoolant interaction (MFCI) type produces both brittle and ductile particles (Büttner et al. 2002; Zimanowski et al. 2015). In contrast, both magmatic and phreatomagmatic fragmentation of rhyolite is typically, though not always (Murch et al. 2019a), a brittle process (Austin-Erickson et al. 2008; Cashman and Scheu 2015; Dürig et al. 2020b). Therefore, the composition of the magma (including the crystals) and/or the melt (now preserved as the groundmass i.e. glass and microlites) needs to be determined before fragmentation rates can be assessed. There are two geochemical strategies, not mutually exclusive, to do this: whole-rock analysis of juvenile pyroclasts, or groundmass analysis by electron microprobe.

\section{Whole-rock analysis of juvenile pyroclasts}

Whole-rock geochemistry is typically reported in petrological studies, and is based on analysis of large juvenile fragments (Cashman and Rust 2016). Fresh, unweathered juvenile bombs or large lapilli should be sampled, and cracked open to make sure that no nonjuvenile (lithic) inclusions are present. At least a fist-sized volume of material is needed for each geochemical analysis (e.g., Webster et al. 1996; Suda et al. 2018). If necessary to obtain sufficient material, several lapilli can be combined into one sample (e.g., Pardo Villaveces 2012) with the assumption of compositional homogeneity. If several juvenile populations appear to be present in the field, based on color, mineralogy or textures, one can either sample the dominant composition, or better, sample each juvenile component.
When performing the analysis, typical quality assurance/quality control procedures should be followed (e.g., Piercey 2014), including the use of certified reference materials. The minimum information to be obtained is major oxides plus loss on ignition (LOI). Major oxides are typically determined by wavelengthdispersive X-ray fluorescence (WD-XRF) (e.g., AustinErickson et al. 2011; Pardo et al. 2014a; Chamberlain et al. 2016), or inductively coupled plasma atomic emission spectroscopy (ICP-AES), also known as ICP-optical emission spectrometry (ICP-OES) (e.g., Kapelanczyk et al. 2012; Gurioli et al. 2018).

\section{Groundmass geochemistry}

Microprobe analyses of the groundmass (glass and microlites) can be done on the polished epoxy grain mounts of juvenile clasts already required for other purposes (see below) and in that case, no additional sampling is necessary. If reported together with phenocryst percentages, species and compositions, this can provide adequate information about magma composition. It has the advantage that it reports information from the particles analyzed, rather than making the assumption that ash compositions match those of large particles, particularly if they cannot be sampled at the same site.

The composition of the groundmass (glass and microlites) represents the melt portion of the magma, without the larger crystals. The composition of the groundmass is typically different from that of the bulk rock (e.g., Pardo et al. 2014a; Cashman and Rust 2016; Suda et al. 2018), unless of course the material is entirely glassy. So the groundmass composition cannot typically be used to name the whole rock. However, since it represents the liquid, the composition of the groundmass is more directly relevant to magma rheology (e.g., viscosity) in a magma fragmentation context (Giordano et al. 2008).

Groundmass composition can be obtained quickly with an electron microprobe, and the focus is typically on analyzing the glass (Andronico et al. 2009). The pyroclasts are mounted in epoxy, polished to get a flat surface, the mount is coated with carbon, and then each grain is analyzed (Hunt and Hill 1993). Attention must be paid to sodium loss, with mitigation strategies including use of a defocused beam (at least 10-20 $\mu \mathrm{m}$ across), low beam current $(\leq 10 \mathrm{nA})$, analysis of $\mathrm{Na}$ first, or timedependent analysis of $\mathrm{Na}$ (Hunt and Hill 1993; Devine et al. 1995; Morgan and London 1996; Gurioli et al. 2008; Hayward 2011; Gaunt et al. 2016). The percentages, types and compositions of phenocrysts should also be reported if they are present in significant abundance. This allows assessment of whether melt and crystals were in equilibrium, as well as offering additional information useful in rock classification.

As an alternative to an electron microprobe, energy dispersive X-ray spectroscopy (EDS) analysis with an SEM may also provide adequate information on groundmass compositions (Taddeucci et al. 2004). We 
recommend that a set of reference standards be analyzed before each session (Caracciolo et al. 2021).

\section{Sieving (standard)}

There are two reasons why sieving is standard in the workflows: to determine particle size distributions and to extract specific size fractions. Both polished epoxy grain mounts (described and justified below) and carbon tape grain mounts (described and justified below) are also best prepared using individual size fractions.

\section{Particle-size distributions}

Grainsize distribution is traditionally one of the criteria used to help distinguish fragmentation styles (e.g., Walker 1973; Wohletz 1983a, 1986; Houghton and Hackett 1984; Barberi et al. 1989; Rust and Cashman 2011; Liu et al. 2015b; White and Valentine 2016; Liu et al. 2017). The classic Walker (1973) diagram for fallout deposits uses the proportion of $<1 \mathrm{~mm}$ particles at $0.1 \mathrm{~T}_{\max }$ (with $\mathrm{T}_{\max }$ the maximum thickness of the deposit) to distinguish phreatomagmatic eruptions from the suite of magmatic fields (Hawaiian to ultraplinian; e.g., Houghton and Gonnermann 2008). There are also sorting versus median size diagrams in the literature where different fields are shown for magmatic versus phreatomagmatic fragmentation (e.g., Houghton and Carey 2015) and also fields for pyroclastic flow, surge and fall (e.g., Walker 1971). Grainsize parameters can also be plotted as a function of distance from the vent (Sparks et al. 1981; Osman et al. 2020). For most cone-like and sheet-like fall deposits, grainsize distributions taken at representative sampling locations (to account for fractionation effects during transport) will provide essential insights into the fragmentation mechanisms that will then be refined by the subsequent analyses suggested here. Note that only the total grain-size distribution estimated over the whole deposit for the eruption or phase investigated is capable of supporting statements about fragmentation separate from transport effects (e.g. Mueller et al 2019).

In general, even total grain-size distribution on its own will not unambiguously reveal primary fragmentation mechanisms, due in part to secondary fragmentation processes such as breakage during transport, especially in PDCs (Wohletz et al. 1989; Büttner et al. 2002; White and Valentine 2016). Taking maar-diatreme volcanoes as an extreme example, beyond the fragmentation mechanism and transport, there are other influences on grain size such as the scaled depth of explosions, topographic effects on jet behavior, country rock mechanical properties and recycling processes (White 1996a; Valentine et al. 2017).

\section{Is 'complete' grainsize distribution needed?}

We present gentle manual dry sieving to $63 \mu \mathrm{m}$ as the standard grainsize technique (Fig. 1), and complementary methods to obtain a complete grainsize distribution are recommended (Fig. 2). The term "complete" is used here to designate a full grainsize characterization for a specific sample, including the fine tail if applicable, with the fine tail analysis based on methods other than sieving (Online Resource 1). If sieving results for a certain sample show a large proportion of fine ash, or a bimodal distribution with a fine mode, then workers are urged to obtain the complete grainsize distribution. Bimodal distributions can have a number of different origins, but might indicate, for example, contemporaneous deposition from a primary plume and a co-PDC plume (Engwell and Eychenne 2016), in which case some or all of the fine constituents in the deposit may not be from primary fragmentation.

\section{Sieving techniques}

Sieving techniques for pyroclastic deposits are described in Online Resource 3.

\section{Our choice of size fractions}

Previous studies on juvenile particles have used a wide range of size fractions (for an overview see Dürig et al. 2019). This is one of the several factors that make data from different volcanoes, eruptions and research groups difficult to compare. In future comparative work, we propose to focus on three representative size fractions for morphological and textural characterization: a medium lapilli fraction (recommended, see Online Resource 1), a coarse ash fraction (standard), and a very fine ash fraction (standard). The fine ash fraction is also used to study the surface features of particles.

Why use three size fractions for comparative studies? A single size fraction is unlikely to be present in all natural pyroclastic deposits, and no single size fraction will capture the entire size range of possible crystals and vesicles. Also, if particles have been affected by several consecutive fragmentation events, this should be easier to recognize if several size fractions are used (Wohletz et al. 1989; Graettinger et al. 2013). We do not recommend studying all possible size fractions for comparative studies since time and resources are limited.

Many existing studies select grain size(s) for detailed morphological and textural studies based on the subpopulations determined from sample grainsize distributions (e.g., Dellino and La Volpe 1995, 1996; Cioni et al. 2008b; Andronico et al. 2013; Bagheri et al. 2015). While work on the modal size fraction(s) is logical and important for studying a specific eruption, it does not produce generalizable data.

\section{Coarse ash fraction (standard)}

The $0.71-0.5 \mathrm{~mm}(+0.5$ to $+1 \phi)$ fraction is our chosen coarse ash fraction, as it is suitable for both morphological and textural characterization using particle cross-sections (see Comida et al. 2022 for details of this choice). It was previously examined by Cioni et al. (2008b), D'Oriano et al. $(2011,2014)$ and Pompilio et al. (2017). Other workers have used fractions close to this in $\phi$ terms:

- Cioni et al. (2014) and Fitch et al. (2017) used $1.4-1.0 \mathrm{~mm}(-0.5$ to $0 \phi)$;

- Miwa and Toramaru (2013) and Mele et al. (2018) selected a $0.5-0.35 \mathrm{~mm}(+1$ to $+1.5 \phi)$ fraction;

- $\quad$ Fitch et al. (2017) used $0.35-0.25 \mathrm{~mm}(+1.5$ to $+2 \phi)$.

The $0.71-0.5 \mathrm{~mm}(+0.5$ to $+1 \phi)$ fraction is likely in many cases to represent the majority of vesicles and crystals, and "capture the internal heterogeneity of the magma" 
(D’Oriano et al. 2014). Ash-sized particles cool from magmatic temperatures to below the glass transition within seconds within air or water, i.e. much more quickly than the interiors of lapilli (e.g., Porritt et al. 2012; Moitra et al. 2018). Therefore, ash particles are small enough to minimize or avoid post-fragmentation effects in terms of phenocryst and microlite growth (D'Oriano et al. 2014; Thivet et al. 2020a) as well as vesicularity (Genareau et al. 2013; Gurioli et al. 2015; Thivet et al. 2020a).

For mafic pyroclasts from Hawaiian or Strombolian eruptions, however, bubble shape at the time of fragmentation may not be fully preserved even in very coarse to coarse ash, due to rapid bubble relaxation (Moitra et al. 2013). The overall morphologies of the $0.71-0.5 \mathrm{~mm}(+0.5$ to $+1 \phi)$ particles might not be fully representative of fragmentation mechanisms, because of several factors, including whole-pyroclast relaxation, especially for ultramafic-mafic magmas (Lindoo et al. 2016). In some other cases, these post-fragmentation processes appear to be negligible, given the almost Gaussian vesicle size distributions and preservation of a large amount of isolated vesicles (Gurioli et al. 2018).

\section{Very fine ash fraction (standard)}

Fine to extremely fine ash allows particle surface features and particle morphologies to be determined on the same carbon tape grain mount. Grains with certain surface features are inferred to have been formed by contact with external water during explosive magma-water interaction, and are called "interactive" particles, based on a comparison between magma fragmentation experiments and nature (Dellino et al. 2001, 2012; Austin-Erickson et al. 2008; Jordan et al. 2014; Murtagh and White 2013; Zimanowski et al. 2015; Valentine and White 2017; Dürig et al. 2020a, 2020b, 2020c).

The overall morphologies of these grains are also highly relevant, since different magma fragmentation mechanisms can produce different morphologies in the fine ash to extremely fine ash range. Unless vesicles are very abundant, these particle morphologies are likely to carry a record of the primary fragmentation process (Wohletz 1983a; Heiken and Wohletz 1985; Dellino et al. 2012; Dürig et al. 2012b), and since they cool extremely quickly, they preserve their diagnostic morphologies, even in ultramafic to mafic magmas. For example, in basalts, magmatic fragmentation can produce fluidalshaped particles, especially for lava fountains (Heiken 1972; Heiken and Wohletz 1991), whereas phreatomagmatic fragmentation can produce a range of particle morphologies, but includes the products of brittle fragmentation (Wohletz 1983a; Zimanowski et al. 1997; Büttner et al. 1999, 2002). These particles are also sufficiently small that few remain in the bedload during transport, so abrasion effects are minimal.

Both the 250-125 $\mu \mathrm{m}(+2$ to $+3 \phi)$ and the $125-63 \mu \mathrm{m}(+3$ to $+4 \phi$ ) fractions are popular in the literature (e.g., Dellino et al. 2012; Colucci et al. 2013; Murtagh and White 2013; Cioni et al. 2014; Pardo et al. 2014b; Liu et al. 2015b; Alvarado et al. 2016; Fitch et al. 2017; Schmith et al. 2017, 2018; Dürig et al. 2020a, 2020b, 2020c). Some workers have also used particles smaller than $63 \mu \mathrm{m}$ (e.g., Wohletz 1983a; Dellino and La Volpe 1995, 1996; Graettinger et al. 2013; Liu et al. 2015b).

We chose the $88-63 \mu \mathrm{m}(+3.5$ to $+4 \phi)$ fraction, which is part of the "very fine ash" range (Table 1), as the optimum fraction because it is the finest that can readily be obtained by sieving, and it maintains the $3 \phi$ spacing between our three fractions. If not enough of these particles are available in a certain sample, the full $125-63 \mu \mathrm{m}$ range could also be used.

The $88-63 \mu \mathrm{m}(+3.5$ to $+4 \phi)$ fraction particles are, however, too small to be representative for the magma vesicularity and crystallinity at fragmentation because larger crystals and vesicles are often larger than the particles (Gurioli et al. 2015; Comida et al. 2022). This is why a coarse ash fraction and, preferably, a medium lapilli fraction, are also studied. Another potential caveat is that certain mildly explosive eruptive styles produce very few fine to extremely fine ash particles so some particles actually found in the $88-63 \mu \mathrm{m}(+3.5$ to $+4 \phi)$ fraction may represent breakage of larger clasts rather than primary magma fragmentation (Thivet al. 2020c).

\section{Ultrasonic cleaning (standard)}

Natural pyroclasts may have adhering finer particles, which hides their true morphologies and surface features. This coating can sometimes make discrimination of juvenile from non-juvenile, and selection of juvenile particles, difficult (e.g., Colucci et al. 2013; Pardo et al. 2014b; Gaunt et al. 2016). A cleaning step is therefore required. This involves short (a few minutes), low intensity ultrasonic cleaning in distilled water, only for the size fractions of interest (Miwa and Toramaru 2013; Alvarado et al. 2016; Liu et al. 2015a, 2017; Gaunt et al. 2016; Mele and Dioguardi 2018; Ort et al. 2018) (Fig. 4d). Using a solution of $\sim 30 \mathrm{ml}$ sodium hexametaphosphate (a dispersing/deflocculating agent) in 1 liter hot water may be useful for older eruptive products (e.g., Casalbore et al. 2010), to facilitate disaggregation. The particles are then dried in an oven, typically at $40-80^{\circ} \mathrm{C}$ (e.g., Miwa and Toramaru 2013; Liu et al. 2015a; Gaunt et al. 2016; Ort et al. 2018). Prolonged, high intensity ultrasonic treatment might damage particles (Cioni et al. 1992), so it should be avoided.

\section{Basic componentry (standard)}

Componentry is the quantification of different types of particles from a volcaniclastic deposit into different categories (bins). The two basic categories are juvenile and non-juvenile (lithic) (White and Houghton 2006). Although juvenile particles are typically glassy, there are some exceptions, like tachylitic grains in some basaltic pyroclastic deposits (Fisher and Schmincke 1984; Taddeucci et al. 2014). Free crystals can be assigned to the juvenile or lithic categories, depending on their inferred provenance. For example, in a basaltic deposit, free pyroxenes might be derived from the magma but loose quartz grains are probably from the country rocks. Free crystals of juvenile origin can often be recognized based on thin rims. If the assignation of free crystals is 
problematic, they can be kept as a distinct category. A final type of fragment consists of "composite" clasts which combine juvenile and lithic material (White and Houghton 2006).

Basic componentry can help separate different eruption types. Phreatic eruptions, by definition, do not produce juvenile particles (e.g., Barberi et al. 1992; Pardo et al. 2014b; Alvarado et al. 2016). Magmatic eruption products can have low to extremely low lithic contents (e.g., Heiken and Wohletz 1987; Valentine and Groves 1996; Allen and McPhie 2000; Valentine 2012). High lithic contents are commonly associated with phreatomagmatic eruptions that excavate deep craters into the country rocks (Doubik and Hill 1999; White and Ross 2011; White and Valentine 2016). However, other processes - such as caldera collapse, vent widening during Plinian eruptions, lithic lag breccias within pyroclastic flows, or flank eruptions during the first days on basaltic volcanoes may also lead to high lithic contents (Taddeucci et al. 2002; White and Valentine 2016 and references therein). In contrast, phreatomagmatic eruptions involving surface water can produce lithic-poor pyroclastic deposits (e.g., White 1996b; Murtagh and White 2013; Agustín-Flores et al. 2015).

Basic componentry involves counting only the basic categories (juvenile, lithic, \pm free crystals, \pm composite) and is a standard step for the coarse ash and very fine ash fractions (Fig. 1). The result of the counting, for each investigated size fraction, is the number of particles from each component versus the total number of particles counted. This approximately corresponds to volumetric proportions, since we are dealing with specific size fractions ${ }^{1}$. A more complete componentry exercise, where juvenile grains are subdivided into types, lithics are separated by stratigraphy, etc., can be very informative, and is recommended (Online Resource 1) but not standard. If full componentry is performed, the results should also be regrouped into the basic categories for ease of comparison with other studies.

The number of grains to be counted depends on the aims of the componentry study. For basic componentry, assuming that the major components have abundances greater than $10-20 \%$, then $200+$ particles are required. This was empirically defined by a sensitivity analysis for samples from the 1977 Ukinrek maar eruption, using low and high lithic abundance samples (Ort et al. 2018). Also, based on the theoretical error chart developed by van der Plas and Tobi (1965) for petrographic point counting, for a component that has a $10 \%$ abundance, counting a total of 200 points will yield an error range for this component slightly larger than $4 \%$ absolute ( $40 \%$ relative), within a $95 \%$ confidence interval (Fig. 4c). Still at 200 points, for a component with $40 \%$ abundance, the error is about $7 \%$ absolute, or $\sim 18 \%$ relative (Fig. $4 c$ ). Ross et al. (2021) have updated the van der Plas and Tobi (1965) charts.

\footnotetext{
${ }^{1}$ An alternative to counting the individual grains in each componentry bin is to weigh the entire bins using a precise analytical balance (Cas and Wright 1987; Barberi et al. 1989), although if different
}

For the $0.71-0.5 \mathrm{~mm}(+0.5$ to $+1 \phi)$ fraction, the user places the grains under the binocular microscope (Suzuki et al. 2013; Gaunt et al. 2016; Murch et al. 2019b), perhaps in a flat petri dish, and counts $200+$ grains manually, with tweezers or a dissection probe, sorting them into basic componentry bins (Fig. 4d). Juvenile clasts should be kept apart to be reused later.

For the $88-63 \mu \mathrm{m}(+3.5$ to $+4 \phi)$ fraction, counting grains under the binocular microscope is tricky to handle with tweezers or a dissection probe, and juvenile identification may be difficult. So componentry is instead performed on a polished epoxy grain mount with SEM imaging, as the internal textures of each grain can then be identified (e.g., Barberi et al. 1989; Pardo et al. 2014b; Jones et al. 2016; Liu et al. 2017). Componentry with an SEM is based largely on internal textures of fragments, but can be aided, or partly automated, by adding chemical/mineralogical mapping with the EDS detector (Hornby et al. 2019; Pardo et al. 2020). To perform basic componentry based on SEM images, software such as the freeware JMicrovision (Roduit 2007; https://jmicrovision.github.io/) can be used on single images or image mosaics. If just enough grains have been mounted, than the "manual point counting" feature of JMicrovision allows the user to count all grains (Fig. 4e). If more than 200 grains have been mounted, then grains can be selected on a square grid, by using the "recursive grid" option, until enough points have been classified.

\section{Juvenile particle selection (standard)}

The $0.71-0.5 \mathrm{~mm}(+0.5$ to $+1 \phi)$ and $88-63 \mu \mathrm{m}(+3.5$ to $+4 \phi)$ fractions might each contain many more juvenile particles than the number needed for characterization of textures, morphologies and surface features. The fractions are also likely to contain non-juvenile clasts and free crystals, which are not wanted in subsequent steps: all morphological and textural measurements described here are to be done exclusively on glassy (or similar) juvenile particles, not on free crystals or lithics. A step of juvenile particle selection is therefore needed.

\section{Coarse ash fraction (standard)}

For the $0.71-0.5 \mathrm{~mm}(+0.5$ to $+1 \phi)$ fraction, juvenile grains are manually set aside, under the binocular microscope, during basic componentry. Among those, 50 juvenile particles are randomly selected, which is more than should be actually needed (Comida et al. 2022). These 50 juvenile particles are then made into a polished epoxy grain mount (Fig. 1).

\section{Very fine ash fraction (standard)}

For the $88-63 \mu \mathrm{m}(+3.5$ to $+4 \phi)$ fraction, juvenile particles are identified on SEM images of particle crosssections during basic componentry. The same particles can be retrospectively located on SEM images of a carbon-tape grain mount, as part of a dual-mounting procedure. When preparing the carbon tape grain mount, mount enough grains to ensure that (1) the carbon tape

components have different densities, weighing the bins will not produce data equivalent to volumetric proportions. 
grain mount retrospectively contains at least 100 juvenile particles and (2) the polished epoxy grain mount contains at least 200 grains in total, for basic componentry (Fig. 1).

\section{Sample preparation for quantitative 2D morphological and internal texture analysis (coarse ash fraction) (standard)}

For the $0.71-0.5 \mathrm{~mm}(+0.5$ to $+1 \phi)$ fraction, the 2D morphological and internal texture measurements require either a polished epoxy grain mount (or 'briquette') (e.g., Maria and Carey 2002; Liu et al. 2015a, 2015b, 2017), or a polished thin section. Comida et al. (2022) present detailed instructions for preparing polished epoxy grain mounts, which are easier to manufacture than polished thin sections. The 50 selected juvenile particles are mounted.

A photo of the whole polished grain mount or polished thin section can be obtained with a high-resolution handheld camera, a binocular microscope or a highresolution flatbed scanner. This photo is then printed, and brought to the SEM for easier navigation.

Dual mounting of the very fine ash fraction (standard) For the $88-63 \mu \mathrm{m}(+3.5$ to $+4 \phi)$ fraction, we established a dual mounting procedure, where $200+$ particles from the bulk fraction (including at least 100 juvenile ones) are first mounted on a carbon tape, imaged with the SEM, and then converted to a polished epoxy grain mount and imaged again. The latter SEM images are used for basic componentry (standard), during which juvenile particles are identified. The same juvenile particles can then be retrospectively found on mirror SEM images of the carbon tape grain mount, to be used for identifying surface features and to make morphology measurements on silhouettes (both standard; Fig. 1). Detailed instructions for the dual mounting procedure are provided in Online Resource 4 and a brief summary is given here.

\section{Carbon tape grain mount}

The procedure starts with a circular double-sided carbon tape being stuck onto an aluminum disk (Fig. 5a). The top will be covered by a non-stick paper circle, on which a smaller circle is drawn, corresponding to the internal diameter of the ring form to be used later for the polished epoxy grain mount (Fig. 5b). The non-stick paper circle is then peeled off from the carbon tape (Fig. $5 \mathrm{c}$ ). We offer four particle transfer methods. In the first quick method, particles are spread on the marked non-stick paper circle, and the sticky (carbon tape) side of the aluminum disc is very gently pressed on the sample (Fig. 5d). In the second quick method, a moistened glove-covered thumb is used to transfer the particles from the non-stick circle to the sticky side of the carbon tape, making sure to press down very gently to avoid crushing fragile grains (Fig. 5e). In the third quick method, a fine-tipped paintbrush is used. For the slow method, particles are transferred and deposited one by one onto the carbon tape, under the binocular microscope. This last method is ideal to get good particle separation but still mount the particles in a restricted area. With all mounting methods, a linear object with a thickness of $\sim 50 \mu \mathrm{m}$ or more is added, to be used as a "horizontal" reference later, during imaging (Fig. 5e). After coating the grain mount with a very thin layer of carbon or gold, it is ready to take to the SEM to image particles (Fig. 5f).

\section{Polished epoxy grain mount}

After SEM imaging, the carbon tape grain mount can be transformed into a polished epoxy grain mount. First, the plastic ring form is glued on the side where particles are present. Then the epoxy is poured (Fig. $5 \mathrm{~g}$ ). After curing, the assembly can be turned upside down (Fig. 5h). The aluminum stub and carbon tape are detached (Fig. 5i). The epoxy mount is then ready for grinding and polishing, the aim being to expose the center of the smallest particle. This leaves a finished polished epoxy grain mount, which can be coated with carbon (Fig. 5j) and taken back to the SEM for imaging (Fig. 5k). The raw SEM images of the polished grain mount should constitute mirror images of the carbon tape grain mount.

\section{Quantitative morphology analysis}

Overview of possible imaging methods

In previous studies, juvenile particle morphologies have been measured in 2D or in 3D. The 2D morphologies have often been based on silhouettes (projections) of 3D particles, acquired by SEM (e.g., Dellino and La Volpe 1996; Dürig et al. 2012b; Jordan et al. 2014; Avery et al. 2017 ) or on optical methods in various particle-sizing and imaging devices, also known as automated particle analyzers (e.g., Leibrandt and Le Pennec 2015; Schmith et al. 2017; Nurfiani and Bouvet de Maisonneuve 2018; Freret-Lorgeril et al. 2019; Thivet et al. 2020a). Alternatively, 2D morphologies can be based on particle cross-sections imaged with a petrographic microscope or an SEM, as long as very careful polishing is performed to preserve the original edge of the grain (e.g., Liu et al 2015a, 2015b; Rausch et al. 2015; Jones et al. 2016; Buckland et al. 2018; Comida et al. 2018; Verolino et al. 2019). Emerging 3D techniques include micro-CT, for which improvements in voxel resolution are enabling increasingly small-scale morphological features to be resolved (e.g., Schipper et al. 2013; Vonlanthen et al. 2015; Dioguardi et al. 2017; Mele and Dioguardi 2018; Mele et al. 2018)

Unfortunately, morphometric parameters measured by the different 2D methods cannot be directly compared (Liu et al. 2015a; Buckland et al. 2018; Nurfiani and Bouvet de Maisonneuve 2018), and tomography cannot yet capture tiny but significant microlites or vesicles visible in SEM. Therefore, we had to make choices here on standard methods for the protocol. Our criteria were equipment accessibility, image acquisition costs (financial and temporal), and versatility. By versatility we mean the possibility of measuring not only morphometric parameters, but other aspects such as componentry, groundmass chemical composition, internal textures and surface features.

Micro-CT provides true 3D information on particle morphologies, surface areas, vesicle sizes, and vesicle number density. Micro-CT is very useful for a number of applications, including study of aerodynamic drag, as 
shown by the papers cited above. However, in the context of the present standardized method for comparative studies, crystals are not always easily distinguishable from glass under X-ray (e.g., Mele et al. 2018), and imaging a sufficiently large number of particles at a high spatial resolution $(\sim 0.5 \mu \mathrm{m})$ involves a large temporal effort, plus computer power. In contrast, SEM methods are currently much more accessible worldwide, are easier to use than micro-CT devices, and also allow chemical (EDS) and crystallographic (e.g. electron backscatter diffraction) analysis if needed.

Automated particle analyzers based on optical methods are fast and are gaining popularity. Internal textures (vesicles and crystals) cannot, however, be assessed with these devices, and it can be difficult to determine whether a certain particle is a juvenile fragment, a non-juvenile (lithic) fragment, or a crystal. Replicability of measured shape populations across the increasing number of different analyzers remains to be established. In the context of comparative fragmentation studies such as those proposed here, we prefer SEM imagery for the standard parameters. Online Resource 1 describes how micro-CT devices and automated particle analyzers can be integrated to perform additional measurements.

We now further consider the two types of SEM imaging for shape analysis in more detail: 2D particle crosssections (using a polished epoxy grain mount) or 2D particle silhouettes (using a carbon tape grain mount), each with its pros and cons (Table 2). Our proposed strategy is to use a polished epoxy grain mount (particle cross-sections) for the $0.71-0.5 \mathrm{~mm}(+0.5$ to $+1 \phi)$ fraction and a dual mounting procedure for the $88-63 \mu \mathrm{m}(+3.5$ to $+4 \phi$ ) fraction (Figs. 1, 2). This maximizes the information output while minimizing the sample preparation and imaging steps. The images should be stored in a lossless format (e.g., TIFF).

\section{Imaging strategy for the coarse ash fraction}

For the $0.71-0.5 \mathrm{~mm}(+0.5$ to $+1 \phi)$ fraction, using a polished epoxy grain of the juvenile fragments (particle cross-sections) allows morphometric parameters, internal textures and groundmass composition to be studied on a single mount. Quantifying internal textures, as well as particle morphologies, is of fundamental importance. For example, vesicles have a strong influence on particle morphologies: the presence of vesicles affects the material properties and stress distribution within glass, and therefore the geometry of brittle breakage (Liu et al. 2015a, 2015b; Mele et al. 2018). Therefore, knowing the vesicularity of the melt or glass at the time of fragmentation should help to interpret morphometric parameters and tease apart information about the magma's ascent versus the signatures of different fragmentation mechanisms. Grain morphologies (and vesicle shapes) are also influenced by crystals (Thivet et al. 2020c). For example, Schmith et al. (2017) noted that their fragmentation diagram could "only be directly applied to phenocryst- and microlite-poor tephras of basaltic composition", because they built their diagrams using such particles. Therefore, we need to document geochemistry, particle morphologies, and internal textures together. The $0.71-0.5 \mathrm{~mm}(+0.5$ to $+1 \phi)$ fraction is ideal for this since the particles are large enough to capture most crystals and bubbles in the magma, yet are small enough to avoid strong post-fragmentation effects.

\section{Imaging strategy for the very fine ash fraction}

For the $88-63 \mu \mathrm{m}(+3.5$ to $+4 \phi)$ fraction, we have developed a dual mounting procedure which involves converting a carbon tape grain mount to a polished epoxy grain mount. SEM images are acquired from both the carbon-tape and epoxy grain mounts using the same magnification, so that mirror images are obtained (Fig. 5). The images from the carbon tape grain mount are used for two purposes: (1) quantifying morphological parameters on silhouettes, and (2) studying surface features, which are diagnostic of some fragmentation processes, for fine to extremely fine ash. The morphology measurements on silhouettes facilitate comparisons with the existing body of literature (see Table 3 in Dürig et al. 2019). Results based on this method were used, for example, to compare tephra grains from different eruptions or products of different eruptive phases (e.g., Dellino and La Volpe 1996a; Cioni et al. 2008b; Dellino et al. 2012; Murtagh and White 2013; Jordan et al. 2014; Iverson et al. 2014; Alvarado et al. 2016) and on products of laboratory fragmentation to infer processes that generated the analyzed tephra particles (e.g., Büttner et al. 2002; Dürig et al. 2012b, 2020b; Schipper et al. 2013; Jordan et al. 2014). Note, however, that previous studies involving morphologies acquired from silhouettes have used a range of size fractions, so care should be taken to compare only particles of the same sizes.

Images from the polished epoxy grain mount are used for basic componentry (described above). Glassy or similar juvenile clasts are identified, their numbers noted, and then the same grains are flagged on the mirror images from the carbon tape grain mount. The dual mounting ensures that only convincing juvenile particles (not lithics or free crystals) are ultimately used to measure morphometric parameters and study surface features (Table 2).

\section{Choice of morphometric parameters}

A wide array of morphometric parameters have been reported by previous workers, as reviewed by Liu et al. (2015a), Leibrandt and Le Pennec (2015), Schmith et al. (2017) and Dürig et al. (2019). As a standard minimum parameter set for a quantitative description of the grains' morphologies, we propose a combination of two systems, the Image Particle Analysis (IPA) parameters of Dellino and La Volpe (1996) and the parameters suggested by Liu et al. (2015a). We chose these two systems because they are well established in the literature and both contain parameters that capture different aspects of shape, as described in the original references. The IPA parameters are often combined in a diagram which aims to distinguish brittle from ductile fragmentation (Büttner et al. 2002). The definitions to be used for these parameters (circularity, compactness, rectangularity, elongation, convexity, solidity and aspect ratio) are provided in Figure 6. Numerous other parameters can also be measured (see Online resource 1). 


\section{Imaging details for the coarse ash fraction}

For the polished epoxy grain mount of the $0.71-0.5 \mathrm{~mm}$ $(+0.5$ to $+1 \phi)$ fraction, the SEM is used in BSE mode (e.g., Liu et al. 2015a; Jones et al. 2016; Buckland et al. 2018), and images are acquired for 50 juvenile particles (see Comida et al. 2022). Several images will be needed to cover each sample.

The magnification and resolution of these images is important, since low quality images do not produce reliable data. Particle perimeters and internal textures depend on image resolution (Dellino and La Volpe 1996; Maria and Carey 2002; Liu et al 2015a; Schmith et al. 2017; Comida et al. 2022). The key metric is the total number of pixels per particle (a.k.a. pixel density), which is a function of both magnification and image resolution. Morphometric parameters are only comparable if the same pixel density is used between different studies. Previous studies, which focused only on particle morphologies, have recommended anywhere from 750 to 5000 pixels per particle (Mele et al. 2011; Dürig et al. 2012b; Liu et al. 2015a; Schmith et al. 2017). However, because internal textures will also be studied on the same images, the required pixel numbers are actually larger for the $0.71-0.5 \mathrm{~mm}(+0.5$ to $+1 \phi)$ fraction, about 20000 pixels to get stable convexity, vesicularity and crystallinity in a range of fragments from the Ukinrek maars (Comida et al. 2022). With attention to particle spacing, image resolution, and magnification, single images can capture 10-20 particles suitable for analysis. Examples of suitable magnification and resolution settings, and advice on imaging details, are provided in Online resource 5 .

Studies aiming to obtain a reliable vesicle-size distribution or crystal-size distribution have recommended a nested imaging procedure, where each particle is imaged at different magnifications (Shea et al. 2010). Here, because we are aiming only for bulk vesicularity and crystallinity as standard parameters, and we are measuring 50 particles per sample, we use only a single image per particle, to save time. We acknowledge that additional imaging may be needed for full microlite quantification.

\section{Imaging details for the very fine ash fraction}

For the carbon tape grain mount of the $88-63 \mu \mathrm{m}(+3.5$ to $+4 \phi)$ fraction, the SEM is used in back-scatter mode and/or secondary electron mode (Goldstein et al. 2017). In our experience, the back-scatter mode produces images that are easier to use for morphological analysis (strong contrast between particle and the background), whereas the secondary electron provides better images for studying surface features. An acceptable compromise might to use only the back-scatter mode, but employ a high enough magnification and resolution to allow surface features to be clearly discernable. Examples of suitable settings are provided in Online resource 5. Again, we stress that it is important to always use the same pixel number so results from different studies are comparable.

For surface features, 100 glassy (or similar) juvenile grains should be classified. Of the 100 grains, a minimum of 50 should be measured for morphological parameters. This minimum number has been set based on previous studies and a stability test using $125-63 \mu \mathrm{m}(+3$ to $+4 \phi)$ ash from the silicic submarine Havre volcano, 2012 eruption (Dürig et al. 2020b). The sample used (HVR159) contained a mixture of particles from four different morphology classes (Murch et al. 2019a, 2019b), including blocky, highly vesicular, fluidal and elongatetubular grains. Using 145 particles, we calculated the averages of four morphometric parameters, progressively adding particles in random order. We calculated the relative difference in percent between the overall average and the average for a specific number of particles (Fig. 7). In this test, the relative difference became less than 5\% relative at 30 particles or less, and the averages for the different morphometric parameters looked very stable beyond 50 grains.

In routine measurements, to verify that enough particles have been measured, we suggest calculating the relative difference in cumulative average morphometric parameters for the $45^{\text {th }}, 46^{\text {th }}, 47^{\text {th }}, 48^{\text {th }}$, and $49^{\text {th }}$ grains. If the relative difference is more than $5 \%$, more grains should be imaged and analyzed.

For the polished epoxy grain mount of the $88-63 \mu \mathrm{m}$ $(+3.5$ to $+4 \phi)$ fraction, the SEM is used again in backscatter mode, and $200+$ grains from the bulk fraction are imaged. Because the only aim is basic componentry (and juvenile identification) in the standard flowchart (Fig. 1), a lower resolution can be employed than for the carbon tape grain mount, significantly reducing imaging time. However, the same SEM magnification should be used, so that the same particles are placed in the field of view both on carbon tape and in the polished epoxy grain mount, for each frame. Examples of suitable SEM settings are provided in Online resource 5.

\section{Measuring the morphometric parameters}

Comida et al. (2022) present a new Fiji code called

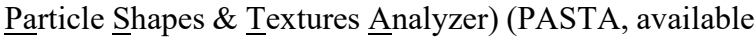
on GitHub: http://doi.org/10.5281/zenodo.3336335) which allows separation of multi-particle images into single-particle images, and binarization. Once the singleparticle binary images are available, they can be further analyzed within PASTA as batches, to yield the Liu et al. (2015a) parameters.

In addition, the single-particle binary images obtained with PASTA can be analyzed with the open source Matlab batch processing script PARTISAN (PARTIcle Shape Analyzer) developed by Dürig et al. (2019). The latest version (Dürig and Bowman 2021) provides 19 basic morphological metrics and 23 non-dimensional morphometric parameters from five different morphometric systems, including those of Dellino and La Volpe (1996), Cioni et al. (2014), Leibrandt and Le Pennec (2015), Liu et al. (2015) and Schmith et al. (2017). The provided results are independent of particle orientation. 
Excluding grains that are too small (post-processing) Juvenile grains that are obviously too small should be excluded from the images. But we also suggest a postprocessing filter to remove grains that may only be slightly below the threshold size. The width of the particle bounding box measured in PARTISAN can be used: the width should be at least equal to the retaining sieve mesh (Comida et al. 2022). Any grains smaller than this threshold are deleted.

\section{Internal textures (coarse ash fraction) Standard textural parameters}

Juvenile pyroclasts comprise glass, and commonly also internal crystals (phenocrysts, microlites) and vesicles. The simplest textural parameters to measure on a routine basis are 2D vesicularity and 2D crystallinity (Polacci et al. 2006). For each particle, these parameters are simply taken as the area occupied by vesicles or crystals, respectively, divided by the total area of the particle. Note that these numbers are different from the $3 \mathrm{D}$ vesicularities and 3D crystallinities, which need tomography or stereological corrections and a knowledge of $3 \mathrm{D}$ vesicle and crystal shapes (e.g., Sahagian and Proussevitch 1998; Higgins 2000; Shea et al. 2010). Other possible textural measurements are described in Online Resource 1.

\section{Preparing the SEM images}

To measure the internal textures, the first step is to prepare the $0.71-0.5 \mathrm{~mm}(+0.5$ to $+1 \phi)$ SEM images of particle cross-sections, typically using photo-processing software (Shea et al. 2009). This is discussed in detail by Comida et al. (2022), who also present an "Action Pack" for Adobe Photoshop to facilitate and partly automate this step, as part of the PASTA package.

\section{Textural measurements}

PASTA transforms prepared greyscale images into segmented images, where the different features such as crystals, glass and vesicles are recolored. From those segmented images, PASTA calculates the $2 \mathrm{D}$ vesicularity and 2D crystallinity for each particle (Comida et al. 2022).

\section{Ash surface features (very fine ash fraction) (standard)}

The surface features of juvenile fine to extremely fine ash particles can provide information on the energy involved in fragmenting the material (Dürig et al. 2012a, 2012b; Zimanowski et al. 2015). They also record secondary processes such as transport and alteration (Wohletz and Krinsley 1978; Wohletz 1983b; Heiken and Wohletz 1985).

\section{Interactive particles}

As explained before, "interactive" particles are formed during phreatomagmatic fragmentation of the fuelcoolant interaction (FCI) type, when very high stress rates are applied where liquid water comes into direct contact with hot magma, allowing very rapid heat transfer and brittle fragmentation (Zimanowski et al. 1997, 2015 and references therein; Austin-Erickson et al. 2008; Dürig et al. 2020b). These interactive particles have generally angular shapes with particular fracture surface patterns, are glassy, and are typically of fine to extremely fine ash size, with specific surface features (Büttner et al. 1999; 2002). A distinction can be made between two types of FCI, depending on the magma composition. Molten fuel coolant interaction (MFCI) works well for ultramafic to mafic magmas and the laboratory version typically involves the engulfment of a liquid water domain into the magma (Zimanowski et al. 1997, 2015). Induced fuel coolant interaction (IFCI) applies to more felsic magmas and involves liquid water flowing into cracks in the magma (Austin-Erickson et al. 2008; Dürig et al. 2020b). Both processes produce the same types of interactive particles.

Laboratory MFCI experiments generate $<5$ to $25 \%$ interactive particles. Interactive particles may be even rarer in nature because of the presence of crystals and lithic clasts in the deposits, and because interactive particles are concentrated in the fine size fractions. In contrast, magma fragmentation experiments where no water is involved do not commonly generate these interactive particles (Zimanowski et al. 1997). Miwa et al. (2009) have described particles displaying possible stepped features from vulcanian explosions. So the proportion of interactive particles must be quantified for many experiments and natural deposits to better understand what proportions are typical of different fragmentation mechanisms.

In MFCI experiments, the rest of the ejected pyroclasts are passive particles (Lorenz et al. 1994; Zimanowski et al. 2015). The morphologies and surface features of passive particles are not diagnostic of the fragmentation process, since passive particles can be generated by a range of fragmentation mechanisms (Zimanowski et al. 1997).

Interactive particles are recognized from their surface features, using the carbon tape grain mount of the 88 $63 \mu \mathrm{m}(+3.5$ to $+4 \phi)$ fraction, under the SEM. Interactive particles include those displaying stepped features, branching quench cracks, and also moss-like particles (e.g., Wohletz 1983; Heiken and Wohletz 1985; Büttner et al. 1999, 2002; Dürig et al. 2012b; Zimanowski et al. 2015; Alvarado et al. 2016; Fitch and Fagents 2020). Because interactive particles make up a small percentage of the total ejected mass, at least 100 particles should be examined, to be confident that all particle types present in the sample are found in the selection. Interactive particles can be counted into classes (stepped fractures, branching quench cracks, and moss-like). All non-interactive particles can simply be labelled "other" for this exercise (see Excel templates in Online Resource 2), although it may also be interesting to count particles with hackle lines separately, as explained below.

Stepped features yield irregular particles with an "uneven surface made up of three-dimensional polyhedral elements" (Zimanowski et al. 2015). They are illustrated in Figs. 8a, 8b, 8e and $8 \mathrm{f}$ (see also Fig. 26.7c in Zimanowski et al. 2015). Stepped features are not to be confused with hackle lines (Quinn 2020), which are not diagnostic of phreatomagmatism. "Hackle" in glass fractography means "steps or lines on the fracture surface 
running parallel to the direction of crack propagation" (Quinn 2020). In other words, hackles can look like steps, but the true "stepped features" of interactive particles are more complex, and the steps occur "one step over the other (in 3D)" as opposed to "one behind the other (in 2D)" (P. Dellino, written commun., 2021). Hackle lines can form during slow or fast cracking (Quinn 2020), so finding one particle with these features is not diagnostic of FCI. However, there are many examples of particles that display both stepped features and hackle lines (Figs. 8e, 8f). Also, some IFCI experiments produce increased proportions of particles with hackle lines relative to similar experiments without water ( $T$. Dürig, unpublished data), so more research seems warranted. In the meantime, counting hackle lines in a separate category could yield interesting data.

Branching quench cracks are fracture networks within fresh (unaltered) glass (Figs. 9a, 9b, and Figs. 26.7a-b in Zimanowski et al. 2015). If in doubt, an EDS analysis (e.g., Alvarado et al. 2016) may be needed to ensure that the glass is indeed fresh, since these fracture networks are not be confused with hydration cracks (Zimanowski et al. 2015). The branching quench cracks are a few microns wide (Büttner et al. 2002) and "form directly after fragmentation due to the sudden quenching and subsequent contraction of still-hot particles (...) due to the fast passage (a few ms) of newly fragmented particles through a domain of liquid water" (Zimanowski et al. 2015).

Moss-like particles are "elements bonded together to form complex irregularly shaped grains" (Büttner et al. 2002) (Figs. 9c). These "elements" are tiny fragments and can be angular (Büttner et al. 2002) to globular (Wohletz 1983) (see also Figs. 26.7e-f in Zimanowski et al. 2015). Moss-like particles are "interpreted in terms of annealing that occurs immediately after brittle fragmentation of very fine particles before effective cooling could act" (Büttner et al. 2002). A better name for these particles might be "welded microaggregates" but the term "moss-like" is entrenched in the literature.

We stress again that only glassy (or similar) juvenile fragments should be examined and counted for this exercise, not non-juvenile fragments or free crystals. This is straightforward with the dual mounting procedure since images of the particle interior are available from the epoxy grain mount.

\section{Secondary surface features}

Care must be taken to discriminate primary surface features, related directly to fragmentation (described above), from secondary ones, which form later due to transport or sieving, as well as by chemical and thermal alteration. Transport of ash in PDCs allows particleparticle collisions. This produces, particularly for larger particles, rounding (edge abrasion), V-shaped depressions, conchoidal fractures, dish-shaped fractures, grooves, and perhaps some cracks (Wohletz and Krinsley 1978; Heiken and Wohletz 1985).
Transport in plumes and PDCs also allows particles in the micron to sub-micron range to adhere to larger particles; this can happen due to water vapor related to phreatomagmatism, but also because of atmospheric moisture, or electrostatic forces (Schumacher and Schmincke 1995). Adhering particles are common on phreatomagmatic ash (Dellino and LaVolpe 1995), but this alone is not a diagnostic criterion (White and Valentine 2016).

Sieving is likely to modify the ash surface, but we are unaware of any detailed study about this effect. The importance of this effect is expected to be reduced at small grain sizes, and is probably minor at $63 \mu \mathrm{m}(+4 \phi)$ for most materials.

Chemical alteration of ash grains has been proposed to occur in the eruption column and within PDCs (Büttner et al. 2002; Zimanowski et al. 2015), but also more slowly, after deposition (Wohletz and Krinsley 1978; Wohletz 1983b). Alteration produces chemical modification of the surface (including palagonitization and hydration), pitted surfaces, and hydration cracks (Wohletz and Krinsley 1978; Zimanowski et al. 2015).

\section{Archiving the images and data}

The original, unmodified, uncompressed SEM images of juvenile fragments should be made available, along with all the measurements. The Excel templates of Online Resource 2 can help standardize the data files. Images and data can submitted as supplementary material with each new paper, if the journal allows it, or to one of the existing online data repositories. It might eventually be more convenient to create a common repository for volcanology (or at least for magma fragmentation studies). Archiving the raw SEM images achieves the following: (1) other morphology or textural parameters might be discovered in the future, that are better at discriminating fragmentation styles, or give different important information; (2) anyone can verify that they obtain the same numbers on the same images (reproducibility of scientific results). Archiving the measurements ensures that future workers can easily compile them.

\section{Data analysis}

In the interest of space, a review of methods for statistical analysis of morphometric data will be presented elsewhere (Dürig et al. 2021). Future work on data analysis will also have to integrate all types of data discussed here.

\section{Discussion and conclusions}

Juvenile pyroclasts contain valuable information on magma state at the time of fragmentation, and about fragmentation processes. At present, no consensus exists in the volcanology community on a standardized methodology to characterize juvenile pyroclasts for comparative fragmentation studies. This makes the data difficult or even impossible to compare among different research groups, for different volcanoes and different eruptions. The methodological variability suggests 
numerous questions are raised by the various methodologies in use, including:

- Is knowing the geochemical composition of the magma important?

- Should the pyroclastic deposits be sieved or not?

- Which size fraction(s) should be further analyzed?

- Should ultrasonic cleaning of the particles be performed?

- How many grains are needed for each sample and size fraction?

- For 2D morphology quantification, should the grains be imaged using projections of 3D shapes (silhouettes) or in cross-section (polished section/briquette)?

- Should we use a binocular microscope, a petrographic microscope, a particle-sizing device, a scanning electron microscope, or a micro-CT device, or all of them for different purposes?

- What are the resolution and magnification needed to best image the grains?

- Which morphometric parameters should be used, and what is their definition?

- What method should be used to quantify the particle morphologies?

- Should internal textures (crystals and bubbles) also be measured, and how?

Only through acquisition of mutually compatible datasets can our community address process-oriented questions such as:

- Are ash surface features important and diagnostic, and how do we recognize interactive particles?

- Do other particle formation mechanisms also have recognizable fingerprints? If so, what are they? How do they form?

In this paper and a companion one (Comida et al. 2022), we have provided and justified answers for most of these questions, and propose a standardized method for characterizing juvenile particles for comparative fragmentation studies. We stress that our standardized method is not intended to curb academic freedom. Instead, the idea is for workers to include at least our standard steps in their workflows, which can also comprise many other parameters. We intend our proposal to be discussed and extended or refined, and plan an international workshop with this as a focus. We hope that a broad consensus can be reached on a uniform methodology, and that this will become the new standard for studying juvenile particles for comparative fragmentation studies. The community will then be able to accumulate consistent data on juvenile pyroclasts from a range of eruption styles, fragmentation mechanisms, magma compositions, crystallinities and vesicularities, using both natural samples and experiments. When enough data is available, new "fragmentation diagrams" can be developed and we may be able to obtain deeper insights into the full panoply of magma-to-pyroclast processes that drive particleproducing volcanic eruptions. These will allow different styles of particle-forming eruptions to be distinguished based on the particles produced.

\section{Acknowledgements}

A number of images presented here (including Online Resource 1) show particles generated during magma fragmentation experiments at the University of Würzburg, with the very beneficial involvement and guidance of Bernd Zimanowski and Ralf Büttner. These experiments were funded by the Natural Sciences and Engineering Research Council of Canada (NSERC), using a Discovery Grant to the first author (RGPIN-2015-06782). This is Laboratory of Excellence ClerVolc contribution number 510. A very early draft of the manuscript was read by Emma Liu, Cathy Cashman and Alison Rust, who all made helpful suggestions. We thank Erin Fitch, an anonymous reviewer and associate editor Benjamin Andrews for constructive reviews.

\section{References}

Agustín-Flores J, Németh K, Cronin SJ, Lindsay JM, Kereszturi G (2015) Construction of the North Head (Maungauika) tuff cone: a product of Surtseyan volcanism, rare in the Auckland Volcanic Field, New Zealand. Bull. Volc. 77:article 11

Allen SR, McPhie J (2000) Water-settling and resedimentation of submarine rhyolitic pumice at Yali, eastern Aegean, Greece. J. Volcanol. Geotherm. Res. 95:285-307

Alvarado GE, Mele D, Dellino P, de Moor JM, Avard G (2016) Are the ashes from the latest eruptions (2010-2016) at Turrialba volcano (Costa Rica) related to phreatic or phreatomagmatic events? J. Volcanol. Geotherm. Res. 327:407-415

Andronico D, Cristaldi A, Del Carlo P, Taddeucci J (2009) Shifting styles of basaltic explosive activity during the 2002-03 eruption of Mt. Etna, Italy. J. Volcanol. Geotherm. Res. 180:110-122

Andronico D, Taddeucci J, Cristaldi A, Miraglia L, Scarlato P, Gaeta M (2013) The 15 March 2007 paroxysm of Stromboli: video-image analysis, and textural and compositional features of the erupted deposit. Bull. Volc. 75:733

Andronico D, Di Roberto A, De Beni E, Behncke B, Bertagnini A, Del Carlo P, Pompilio M (2018) Pyroclastic density currents at Etna volcano, Italy: The 11 February 2014 case study. J. Volcanol. Geotherm. Res. 357:92-105

Austin-Erickson A, Büttner R, Dellino P, Ort MH, Zimanowski B (2008) Phreatomagmatic explosions of rhyolitic magma: experimental and field evidence. J. Geophys. Res. 113:paper B11201

Austin-Erickson A, Ort MH, Carrasco-Núñez G (2011) Rhyolitic phreatomagmatism explored: Tepexitl tuff ring (Eastern Mexican Volcanic Belt). J. Volcanol. Geotherm. Res. 201:325-341

Avery MR, Panter KS, Gorsevski PV (2017) Distinguishing styles of explosive eruptions at Erebus, Redoubt and Taupo volcanoes using multivariate analysis of ash morphometrics. J. Volcanol. Geotherm. Res. 332:1-13

Bagheri GH, Bonadonna C, Manzella I, Vonlanthen P (2015) On the characterization of size and shape of irregular particles. Powder Tech. 270:141-153.

Barberi F, Cioni R, Rosi M, Santacroce R, Sbrana A, Vecci R (1989) Magmatic and phreatomagmatic phases in explosive eruptions of Vesuvius as deduced by grain-size and component analysis of the pyroclastic deposits. J. Volcanol. Geotherm. Res. 38:287-307 
Barberi F, Bertagnini A, Landi P, Principe C (1992) A review on phreatic eruptions and their precursors. J. Volcanol. Geotherm. Res. 52:231-246

Beget JE, Larsen JF, Neal CA, Nye CJ, Schaefer JR (2005) Preliminary volcano-hazard assessment for Okmok volcano, Umnak Island Alaska. In: Alaska Department of Natural Resources, Division of Geological \& Geophysical Surveys, Report of Investigations 2004-3

Bernard B (2013) Homemade ashmeter: a low-cost, highefficiency solution to improve tephra field-data collection for contemporary explosive eruptions. J. Appl. Volc. 2:article 1

Bernard J, Le Pennec JL (2016) The milling factory: Componentry-dependent fragmentation and fines production in pyroclastic flows. Geology 44:907-910

Bonadonna C, Cioni R, Costa A, et al. (2016) MeMoVolc report on classification and dynamics of volcanic explosive eruptions. Bull. Volc. 78:article 84

Brand BD, Gravley DM, Clarke AB, Lindsay JM, Bloomberg SH, Agustin-Flores J, Németh K (2014) A combined field and numerical approach to understanding dilute pyroclastic density current dynamics and hazard potential: Auckland Volcanic Field, New Zealand. J. Volcanol. Geotherm. Res. 276:215-232

Buckland HM, Eychenne J, Rust AC, Cashman KV (2018) Relating the physical properties of volcanic rocks to the characteristics of ash generated by experimental abrasion. J. Volcanol. Geotherm. Res. 349:335-350

Bursik M, Kuehn S, Pouget S, Wallace K, et al. (2015) Tephra 2014: summary and consensus document; Appendix I Checklist for tephra collection. Downloaded from https://vhub.org/resources/3860/supportingdocs on December 3, 2018

Bustillos J, Romero JE, Troncoso L, Guevara A (2016) Tephra fall at Tungurahua volcano (Ecuador) - 1999-2014: An example of tephra accumulation from a long-lasting eruptive cycle. Geofis. Intl. 55:55-67

Büttner R, Dellino P, Zimanowski B (1998) Physics of thermohydraulic explosions. Phys. Rev. E 57, 5726-5729

Büttner R, Dellino P, Zimanowski B (1999) Identifying magmawater interaction from the surface features of ash particles. Nature 401:688-690

Büttner R, Dellino P, La Volpe L, Lorenz V, Zimanowski B (2002) Thermohydraulic explosions in phreatomagmatic eruptions as evidenced by the comparison between pyroclasts and products from Molten Fuel Coolant Interaction experiments. J. Geophys. Res. 107:Art. 2277

Caracciolo A, Gurioli L, Marianelli P, Bernard J, Harris AJL (2021) Textural and chemical features of a "soft" plug emitted during Strombolian explosions: A case study from Stromboli volcano. Earth Planet. Sci. Lett. 559:116761

Carey S, Sparks RSJ (1986) Quantitative models of the fallout and dispersal of tephra from volcanic eruption columns. Bull. Volc. 48:109-125

Cas RAF, Wright JV (1987) Volcanic successions, modern and ancient. Allen \& Unwin, London, 528 p.

Casalbore D, Romagnoli C, Chiocci F, Frezza V (2010) Morpho-sedimentary characteristics of the volcaniclastic apron around Stromboli volcano (Italy). Marine Geol. 269:132-148

Cashman KV, Scheu B (2015) Magmatic fragmentation. In: Sigurdsson H, Houghton B, McNutt SR, Rymer H, Stix J (eds) Encyclopedia of Volcanoes, Second edition. Academic Press, London, pp 459-471

Cashman K, Rust A (2016) Volcanic ash: Generation and spatial variations. In: Mackie S, Cashman K, Ricketts H, Rust A, Watson M (eds) Volcanic Ash. Elsevier, pp 5-22

Chamberlain KJ, Barclay J, Preece K, Brown RJ, Davidson JP (2016) Origin and evolution of silicic magmas at ocean islands: Perspectives from a zoned fall deposit on
Ascension Island, South Atlantic. J. Volcanol. Geotherm. Res. 327:349-360

Cioni R, Sbrana A, Vecci R (1992) Morphologic features of juvenile pyroclasts from magmatic and phreatomagmatic deposits of Vesuvius. J. Volcanol. Geotherm. Res. 51:6178

Cioni R, Sulpizio R, Garruccio N (2003) Variability of the eruption dynamics during a Subplinian event: the Greenish Pumice eruption of Somma-Vesuvius (Italy). J. Volcanol. Geotherm. Res. 124:89-114

Cioni R, Bertagnini A, Santacroce R, Andronico D (2008a) Explosive activity and eruption scenarios at SommaVesuvius (Italy): Towards a new classification scheme. J. Volcanol. Geotherm. Res. 178:331-346

Cioni R, D'Oriano C, Bertagnini A (2008b) Fingerprinting ash deposits of small scale eruptions by their physical and textural features. J. Volcanol. Geotherm. Res. 177:277287

Cioni R, Pistolesi M, Bertagnini A, Bonadonna C, Hoskuldsson A, Scateni B (2014) Insights into the dynamics and evolution of the 2010 Eyjafjallajökull summit eruption (Iceland) provided by volcanic ash textures. Earth Planet. Sci. Lett. 394:111-123

Colo' L, Ripepe M, Gurioli L, Harris AJL (2020) Fragmentation processes during strombolian explosions revealed using particle size distribution mapping. Front. Earth Sci. 8:356

Comida PP, Ross P-S, Zimanowski B, Büttner R (2017) Artificial juvenile pyroclasts from wet and dry "eruptions": impact of magma composition on grain sizes and particle shapes. IAVCEI 2017, Portland, Oregon, USA

Comida PP, Ross P-S, Lefebvre N, Zimanowski B, Büttner R (2018) Phreatomagmatic versus magmatic fragmentation: Insights from juvenile particle analysis. Cities on Volcanoes 10, Naples, Italy

Comida PP, Ross P-S, Dürig T, White JDL, Lefebvre N (2022) Standardized analysis of juvenile pyroclasts in comparative studies of primary magma fragmentation; 2 . Choice of size fractions and method optimization. Bull. Volc. 84:article 13

Colucci S, Palladino DM, Mulukutla GK, Proussevitch AA (2013) 3-D reconstruction of ash vesicularity: Insights into the origin of ash-rich explosive eruptions. J. Volcanol. Geotherm. Res. 255:98-107

Dellino P, La Volpe L (1995) Fragmentation versus transportation mechanisms in the pyroclastic sequence of Monte Pilato-Rocche Rosse (Lipari, Italy). J. Volcanol. Geotherm. Res. 64:211-231

Dellino P, La Volpe L (1996) Image processing analysis in reconstructing fragmentation and transportation mechanisms of pyroclastic deposits. The case of Monte Pilato-Rocche Rosse eruptions, Lipari (Aeolian islands, Italy). J. Volcanol. Geotherm. Res. 71:13-29

Dellino P, Isaia R, La Volpe L, Orsi G (2001) Statistical analysis of textural data from complex pyroclastic sequences: implications for fragmentation processes of the AgnanoMonte Spina Tephra (4.1 ka), Phlegraean Fields, southern Italy. Bull. Volc. 63:443-461

Dellino P, Gudmundsson MT, Larsen G, Mele D, Stevenson JA, Thordarson T, Zimanowski B (2012) Ash from the Eyjafjallajökull eruption (Iceland): Fragmentation processes and aerodynamic behavior. J. Geophys. Res. Solid Earth 117:B00C04

Devine JD, Gardner JE, Brack HP, Layne GD, Rutherford MJ (1995) Comparison of microanalytical methods for estimating $\mathrm{H}_{2} \mathrm{O}$ contents of silicic volcanic glasses, Am. Mineral. 80:319-328

Dioguardi F, Mele D, Dellino P, Dürig T (2017) The terminal velocity of volcanic particles with shape obtained from 3D 
X-ray microtomography. J. Volcanol. Geotherm. Res. 329:41-53

D’Oriano C, Bertagnini A, Pompilio M (2011) Ash erupted during normal activity at Stromboli (Aeolian Islands, Italy) raises questions on how the feeding system works. Bull. Volc. 73:471-477

D'Oriano C, Bertagnini A, Cioni R, Pompilio M (2014) Identifying recycled ash in basaltic eruptions. Scientific Reports 4:article 5851

Doubik P, Hill BE (1999) Magmatic and hydromagmatic conduit development during the 1975 Tolbachik Eruption, Kamchatka, with implications for hazards assessment at Yucca Mountain, NV. J. Volcanol. Geotherm. Res. 91:4364

Dürig T, Zimanowski B (2012) "Breaking news" on the formation of volcanic ash: Fracture dynamics in silicate glass. Earth Planet. Sci. Lett. 335:1-8

Dürig T, Bowman HM (2021) lsschmidt/PARTISAN (Version 2.0, March 10, 2021), https://github.com/lsschmidt/PARTISAN/tree/v2.0, DOI 10.5281/zenodo.4593833

Dürig T, Sonder I, Zimanowski B, Beyrichen H, Büttner R (2012a) Generation of volcanic ash by basaltic volcanism. J. Geophys. Res. 117, B01204.

Dürig T, Mele D, Dellino P, Zimanowski B (2012b) Comparative analyses of glass fragments from brittle fracture experiments and volcanic ash particles. Bull. Volc. 74:691-704

Dürig T, Bowman MH, White JDL, Murch A, Mele D, Verolino A, Dellino P (2019) PARTIcle Shape ANalyzer PARTISAN - an open source tool for multi-standard twodimensional particle morphometry analysis. Annals of Geophysics 61: AC31, DOI:10.4401/ag-7865

Dürig T, Schmidt LS, White JDL, Bowman MH (2020a) DendroScan: an open source tool to conduct comparative statistical tests and dendrogrammatic analyses on particle morphometry. Sci. Rep. 10: article 21682

Dürig T, White JDL, Murch AP, Zimanowski B, Büttner R, Mele D, Dellino P, Carey RJ, Schmidt LS, Spitznagel N (2020b) Deep-sea eruptions boosted by induced fuelcoolant explosions. Nature Geosci. 13:498-503

Dürig T, White JDL, Zimanowski B, Büttner R, Murch A, Carey RJ $(2020 \mathrm{c})$

Deep-sea fragmentation style of Havre revealed by dendrogrammatic analyses of particle morphometry. Bull. Volc. 82: article 67

Dürig T, Ross P-S, Dellino P, White JDL, Mele D, Comida PP (2021) A review of statistical tools for morphometric analysis of juvenile pyroclasts. Bull. Volc. 83:article 79

Engwell S, Eychenne J (2016) Contribution of fine ash to the atmosphere from plumes associated with pyroclastic density currents. In: Shona M, Cashman K, Ricketts H, Rust A, Watson M (eds) Volcanic Ash, Elsevier, pp 67-85

Eychenne J, Le Pennec J-L (2012) Sigmoidal particle density distribution in a subplinian scoria fall deposit. Bull. Volc. 74:2243-2249

Eychenne J, Le Pennec J.-L, Troncoso L, Gouhier M, Nedelec J-M (2012) Causes and consequences of bimodal grainsize distribution of tephra fall deposited during the August 2006 Tungurahua eruption (Ecuador). Bull. Volc. 74:187205

Eychenne J, Houghton BF, Swanson DA, Carey RJ, Swavely L (2015) Dynamics of an open basaltic magma system: The 2008 activity of the Halema'uma'u Overlook vent, Kīlauea Caldera. Earth Planet. Sci. Lett. 409:49-60

Freret-Lorgeril V, Donnadieu F, Eychenne J, Soriaux C, Latchimy $T$ (2019) In situ terminal settling velocity measurements at Stromboli volcano: Input from physical characterization of ash. J. Volcanol. Geotherm. Res. 374:62-79
Fisher RV, Schmincke H-U (1984) Pyroclastic Rocks. SpringerVerlag, Berlin, $472 \mathrm{p}$.

Fitch EP, Fagents SA (2020) Characteristics of rootless tephra emplaced by high-energy lava-water explosions. Bull. Volc. 82:article 62

Fitch EP, Fagents SA, Thordarson T, Hamilton CW (2017) Fragmentation mechanisms associated with explosive lava-water interactions in a lacustrine environment. Bull. Volc. 79:12

Gaunt HE, Bernard B, Hidalgo S, Proaño A, Wright H, Mothes P, Criollo E, Kueppers U (2016) Juvenile magma recognition and eruptive dynamics inferred from the analysis of ash time series: The 2015 reawakening of Cotopaxi volcano. J. Volcanol. Geotherm. Res. 328:134146

Genareau K, Mulukutla GK, Proussevitch AA, Durant AJ, Rose WI, Sahagian DL (2013) The size range of bubbles that produce ash during explosive volcanic eruptions. Journal of Applied Volcanology 2:article 4

Giordano D, Russell JK, Dingwell DB (2008) Viscosity of magmatic liquids: A model. Earth Planet. Sci. Lett. 271:123-134

Goldstein JI, Newbury DE, Michael JR, Ritchie NW, Scott, JHJ, Joy, DC (2017) Scanning electron microscopy and X-ray microanalysis. Springer.

Graettinger AH, Valentine GA (2017) Evidence for the relative depths and energies of phreatomagmatic explosions recorded in tephra rings. Bull. Volc. 79:article 88

Graettinger AH, Skilling I, McGarvie D, Höskuldsson Á (2013) Subaqueous basaltic magmatic explosions trigger phreatomagmatism: A case study from Askja, Iceland. J. Volcanol. Geotherm. Res. 264:17-35

Gurioli L, Harris AJL, Houghton BF, Polacci M, Ripepe M (2008) Textural and geophysical characterization of explosive basaltic activity at Villarrica volcano. Journal of Geophysical Research: Solid Earth 113, doi 10.1029/2007JB005328

Gurioli L, Sulpizio R, Cioni R, Sbrana A, Santacroce R, Luperini W, Andronico D (2010) Pyroclastic flow hazard assessment at Somma-Vesuvius based on the geological record. Bull. Volc. 72:1021-1038

Gurioli L, Andronico D, Bachelery P, Balcone-Boissard H, Battaglia J, Boudon G, Burgisser A, Burton MR, Cashman K, Cichy S, Cioni R, et al. (2015) MeMoVolc consensual document: a review of cross-disciplinary approaches to characterizing small explosive magmatic eruptions. Bull. Volc. 77:49

Gurioli L, Di Muro A, Vlastélic I, Moune S, Thivet S, et al. (2018) Integrating field, textural, and geochemical monitoring to track eruption triggers and dynamics: a case study from Piton de la Fournaise. Solid Earth 9:431-455

Harris AJL, Battaglia J, Donnadieu F, Gurioli L, Kelfoun K, Labazuy P, Sawyer G, Valade S, Bombun M, Barra V, Delle Donne D, Lacanna G (2013) Full bandwidth remote sensing for total parameterization of volcanic plumes. Eos 94:321-322

Hayward C (2011) High spatial resolution electron probe microanalysis of tephras and melt inclusions without beam-induced chemical modification. The Holocene 22:119-125

Heiken G (1972) Morphology and petrography of volcanic ashes. Geol. Soc. Am. Bull. 83:1961-1988

Heiken G (1974) An atlas of volcanic ash. Smithsonian Contributions to the Earth Sciences 12, $101 \mathrm{p}$.

Heiken G, Wohletz K (1985) Volcanic ash. University of California Press, Berkeley, California, $246 \mathrm{p}$

Heiken G, Wohletz K (1987) Tephra deposits associated with silicic domes and lava flows. In: Fink JH (ed) The Emplacement of Silicic Domes and Lava Flows. 
Geological Society of America, Special Paper 212, pp 5576

Heiken G, Wohletz K (1991) Fragmentation processes in explosive volcanic eruptions. In: Fisher RV, Smith GA (eds) Sedimentation in volcanic settings. Society of Economic Paleontologists and Mineralogists, Special Publication 45, pp 19-26

Higgins MD (2000) Measurement of crystal size distributions. American Mineralogist 85:1105-1116

Hornby AJ, Lavallée Y, Kendrick JE, Rollinson G, Butcher AR, Clesham S, Kueppers U, Cimarelli C, Chigna G (2019) Phase partitioning during fragmentation revealed by QEMSCAN Particle Mineralogical Analysis of volcanic ash. Scientific Reports 9:126

Houghton B, Hackett W (1984) Strombolian and phreatomagmatic deposits of Ohakune Craters, Ruapehu, New Zealand: a complex interaction between external water and rising basaltic magma. J. Volcanol. Geotherm. Res. 21:207-231

Houghton B, Wilson CJN (1989) A vesicularity index for pyroclastic deposits. Bull. Volc. 51:451-462

Houghton BF, Smith RT (1993) Recycling of magmatic clasts during explosive eruptions: estimating the true juvenile content of phreatomagmatic volcanic deposits. Bull. Volc. $55: 414-420$

Houghton BF, Gonnermann HM (2008) Basaltic explosive volcanism: Constraints from deposits and models. Chemie der Erde - Geochemistry 68:117-140

Houghton B, Carey RJ (2015) Pyroclastic fall deposits. In: Sigurdsson H, Houghton B, McNutt SR, Rymer H, Stix J (eds) The Encyclopedia of Volcanoes, Second Edition. Academic Press, London, pp 599-616

Houghton BF, Wilson CJN, Fierstein J, Hildreth W (2004) Complex proximal deposition during the Plinian eruptions of 1912 at Novarupta, Alaska. Bull. Volc. 66:95-133

Houghton BF, Swanson DA, Rausch J, Carey RJ, Fagents SA, Orr TR (2013) Pushing the Volcanic Explosivity Index to its limit and beyond: Constraints from exceptionally weak explosive eruptions at Kîlauea in 2008. Geology 41:627630

Hunt JB, Hill PG (1993) Tephra geochemistry: a discussion of some persistent analytical problems. The Holocene 3:271278

Jerolmack DJ, Reitz MD, Martin RL (2011) Sorting out abrasion in a gypsum dune field. J. Geophys. Res. 116(F2):F02003

Jones TJ, Russell JK (2017) Ash production by attrition in volcanic conduits and plumes. Sci. Rep. 7:article 5538

Jones TJ, McNamara K, Eychenne J, Rust AC, Cashman KV, Scheu B, Edwards R (2016) Primary and secondary fragmentation of crystal-bearing intermediate magma. J. Volcanol. Geotherm. Res. 327:70-83

Jordan SC, Dürig T, Cas RAF, Zimanowski B (2014) Processes controlling the shape of ash particles: Results of statistical IPA. J. Volcanol. Geotherm. Res. 288:19-27

Jordan SC, Le Pennec JL, Gurioli L, Roche O, Boivin P (2016) Highly explosive eruption of the monogenetic $8.6 \mathrm{ka} \mathrm{BP}$ La Vache et Lassolas scoria cone complex (Chaîne des Puys, France). J. Volcanol. Geotherm. Res. 313:15-28

Kapelanczyk L, Rose WI, Jicha B (2012) An eruptive history of Maderas volcano using new ${ }^{40} \mathrm{Ar} /{ }^{39} \mathrm{Ar}$ ages and geochemical analyses. Bull. Volc. 74:2007-2021

Krumbein WC (1934) Size frequency distributions of sediments. J. Sedim. Res. 2:65-77

Kuenen PH (1960) Experimental abrasion; 4, Eolian action. J. Geol. 68:427-449

Lautze NC, Taddeucci J, Andronico D, Cannata C, Tornetta L, Scarlato P, Houghton B, Lo Castro MD (2012) SEMbased methods for the analysis of basaltic ash from weak explosive activity at Etna in 2006 and the 2007 eruptive crisis at Stromboli. Physics and Chemistry of the Earth 4546:113-127

Lautze NC, Taddeucci J, Andronico D, Houghton B, Niemeijer A, Scarlato PG (2013) Insights into explosion dynamics and the production of ash at Stromboli from samples collected in real-time, October 2009. In: Rose WI, Palma JL, Delgado Granados H, Varley N (eds) Understanding open-vent volcanism and related hazards, GSA Special Paper 498, pp 125-139

Leibrandt S, Le Pennec J-L (2015) Towards fast and routine analyses of volcanic ash morphometry for eruption surveillance applications. J. Volcanol. Geotherm. Res. 297:11-27

Lindoo A, Larsen JF, Cashman KV, Dunn AL, Neill OK (2016) An experimental study of permeability development as a function of crystal-free melt viscosity. Earth Planet. Sci. Lett. 435:45-54

Liu EJ, Cashman KV, Rust AC (2015a) Optimising shape analysis to quantify volcanic ash morphology. GeoResJ 8:14-30

Liu EJ, Cashman KV, Rust AC, Gislason SR (2015b) The role of bubbles in generating fine ash during hydromagmatic eruptions. Geology 43:239-242

Liu EJ, Cashman KV, Rust AC, Höskuldsson A (2017) Contrasting mechanisms of magma fragmentation during coeval magmatic and hydromagmatic activity: the Hverfjall Fires fissure eruption, Iceland. Bull. Volc. 79:68

Lorenz V, Zimanowski B, Fröhlich G (1994) Experiments on explosive basic and ultrabasic, ultramafic, and carbonatitic volcanism. Proc 5th Int Kimb Conf, Araxa, Brazil, CPRM Special Publication 1, p. 270-284.

Manga M, Patel A, Dufek J (2011) Rounding of pumice clasts during transport: field measurements and laboratory studies. Bull. Volc. 73:321-333

Maria A, Carey S (2002) Using fractal analysis to quantitatively characterize the shapes of volcanic particles. J. Geophys. Res. Solid Earth 107:ECV 7-1-ECV 7-17

Mele D, Dioguardi F (2018) The grain size dependency of vesicular particle shapes strongly affects the drag of particles. First results from microtomography investigations of Campi Flegrei fallout deposits. J. Volcanol. Geotherm. Res. 353:18-24

Mele D, Dellino P, Sulpizio R, Braia G (2011) A systematic investigation on the aerodynamics of ash particles. J. Volcanol. Geotherm. Res. 203:1-11

Mele D, Dioguardi F, Dellino P (2018) A study on the influence of internal structures on the shape of pyroclastic particles by X-ray microtomography investigations. Annals of Geophysics 61:AC27

Miwa T, Toramaru A (2013) Conduit process in vulcanian eruptions at Sakurajima volcano, Japan: Inference from comparison of volcanic ash with pressure wave and seismic data. Bull. Volc. 75:685

Miwa T, Toramaru A, Iguchi M (2009) Correlations of volcanic ash texture with explosion earthquakes from vulcanian eruptions at Sakurajima volcano, Japan. J. Volcanol. Geotherm. Res. 184:473-486

Moitra P, Gonnermann HM, Houghton BF, Giachetti T (2013) Relating vesicle shapes in pyroclasts to eruption styles. Bull. Volc. 75:691

Moitra P, Sonder I, Valentine GA (2018) Effects of size and temperature-dependent thermal conductivity on the cooling of pyroclasts in air. Geochemistry, Geophysics, Geosystems 19:3623-3636

Morgan GB, London D (1996) Optimising the electron microprobe analysis of hydrous alkali aluminosilicate glasses. Am. Mineral. 81:1176-1185

Mosley MP, Tindale DS (1985) Sediment variability and bed material sampling in gravel-bed rivers. Earth Surf Proc Land 10:465-482 
Mueller SB, Houghton BF, Swanson DA, Fagents SA, Klawonn M (2018) Intricate episodic growth of a Hawaiian tephra deposit: case study of the 1959 Kîlauea Iki eruption. Bull. Volc. 80:article 73

Mueller SB, Houghton BF, Swanson DA, Poret M, Fagents SA (2019) Total grain size distribution of an intense Hawaiian fountaining event: case study of the 1959 Killauea Iki eruption. Bull. Volc. 81:article 43

Murch AP, White JDL, Carey RJ (2019a) Unusual fluidal behavior of a silicic magma during fragmentation in a deep subaqueous eruption, Havre volcano, southwestern Pacific Ocean. Geology 47: 487-490

Murch AP, White JDL, Carey RJ (2019b) Characteristics and deposit stratigraphy of submarine-erupted silicic ash, Havre Volcano, Kermadec arc, New Zealand. Frontiers in Earth Science 7:article 1

Murtagh RM, White JDL (2013) Pyroclast characteristics of a subaqueous to emergent Surtseyan eruption, Black Point volcano, California. J. Volcanol. Geotherm. Res. 267:7591

Németh K, Cronin SJ, Smith IEM, Agustin Flores J (2012) Amplified hazard of small-volume monogenetic eruptions due to environmental controls, Orakei Basin, Auckland Volcanic Field, New Zealand. Bull. Volc. 74:2121-2137

Nurfiani D, Bouvet de Maisonneuve C (2018) Furthering the investigation of eruption styles through quantitative shape analyses of volcanic ash particles. J. Volcanol. Geotherm. Res. 354:102-114

Ort MH, Lefebvre NS, Neal CA, McConnell VS, Wohletz KH (2018) Linking the Ukinrek 1977 maar-eruption observations to the tephra deposits: New insights into maar depositional processes. J. Volcanol. Geotherm. Res. 360:36-60

Osman S, Beckett F, Rust A, Snee E (2020) Sensitivity of volcanic ash dispersion modelling to input grain size distribution based on hydromagmatic and magmatic deposits. Atmosphere 11:567

Pardo Villaveces N (2012) Andesitic Plinian eruptions at Mt. Ruapehu (New Zealand): from lithofacies to eruption dynamics. PhD thesis, Massey University, New Zealand

Pardo N, Cronin SJ, Wright HMN, Schipper CI, Smith I, Stewart B (2014a) Pyroclast textural variation as an indicator of eruption column steadiness in andesitic Plinian eruptions at Mt. Ruapehu. Bull. Volc. 76:822

Pardo N, Cronin SJ, Németh K, Brenna M, Schipper CI, Breard E, White JDL, Procter J, Stewart B, Agustín-Flores J, Moebis A, Zernack A, Kereszturi G, Lube G, Auer A, Neall V, Wallace C (2014b) Perils in distinguishing phreatic from phreatomagmatic ash; insights into the eruption mechanisms of the 6 August 2012 Mt. Tongariro eruption, New Zealand. J. Volcanol. Geotherm. Res. 286:397-414

Pardo N, Avellaneda JD, Rausch J, Jaramillo-Vogel D, Gutiérrez M, Foubert A (2020) Decrypting silicic magma/plug fragmentation at Azufral crater lake, Northern Andes: insights from fine to extremely fine ash morpho-chemistry. Bull. Volc. 82:article 79

Piercey SJ (2014) Modern analytical facilities 2. A review of quality assurance and quality control $(\mathrm{QA} / \mathrm{QC})$ procedures for lithogeochemical data. Geoscience Canada 41:75-88

Pioli L, Erlund E, Johnson E, Cashman K, Wallace P, Rosi M, Delgado Granados H (2008) Explosive dynamics of violent Strombolian eruptions: The eruption of Parícutin Volcano 1943-1952 (Mexico). Earth Planet. Sci. Lett. 271:359-368

Pistolesi M, Bertagnini A, Di Roberto A, Isaia R, Vona A, Cioni R, Giordano G (2017) The Baia-Fondi di Baia eruption at Campi Flegrei: stratigraphy and dynamics of a multi-stage caldera reactivation event. Bull. Volc. 79:article 67
Polacci M, Corsaro RA, Andronico D (2006) Coupled textural and compositional characterization of basaltic scoria: Insights into the transition from Strombolian to fire fountain activity at Mount Etna, Italy. Geology 34:201204

Polacci M, Andronico D, de' Michieli Vitturi M, Taddeucci J, Cristaldi A (2019) Mechanisms of ash generation at basaltic volcanoes: the case of Mount Etna, Italy. Frontiers in Earth Science 7:article 193

Pompilio M, Bertagnini A, Del Carlo P, Di Roberto A (2017) Magma dynamics within a basaltic conduit revealed by textural and compositional features of erupted ash: the December 2015 Mt. Etna paroxysms. Scientific Reports 7:4805

Porritt LA, Russell JK, Quane SL (2012) Pele's tears and spheres: examples from Kilauea Iki. Earth Planet. Sci. Lett. 333:171-180

Prival J-M, Thouret J-C, Japura S, Gurioli L, Bonadonna C, Mariño J, Cueva K (2019) New insights into eruption source parameters of the $1600 \mathrm{CE}$ Huaynaputina Plinian eruption, Peru. Bull. Volc. 82:article 7

Quinn GD (2020) Fractography of ceramics and glasses. NIST Special Publication 960-16e3, doi 10.6028/NIST.SP.960$16 \mathrm{e} 3$

Rausch J, Grobéty B, Vonlanthen P (2015) Eifel maars: Quantitative shape characterization of juvenile ash particles (Eifel Volcanic Field, Germany). J. Volcanol. Geotherm. Res. 291:86-100

Roduit N (2007) JMicroVision : un logiciel d'analyse d'images pétrographiques polyvalent. $\mathrm{PhD}$ thesis, Université de Genève.

Ross P-S, White JDL (2012) Quantification of vesicle characteristics in some diatreme-filling deposits, and the explosivity levels of magma-water interactions within diatremes. J. Volcanol. Geotherm. Res. 245-246:55-67

Ross P-S, Giroux B, Latutrie B (2021) Precision and accuracy of modal analysis methods for clastic deposits and rocks: A statistical and numerical modeling approach. Geosphere 17: doi 10.1130/GES02374.1

Rust AC, Cashman KV (2011) Permeability controls on expansion and size distributions of pyroclasts. J. Geophys. Res.: Solid Earth 116(B11), doi:10.1029/2011JB008494

Sahagian DL, Proussevitch AA (1998) 3D particle size distributions from 2D observations: stereology for natural applications. J. Volcanol. Geotherm. Res. 84:173-196

Saxby J, Rust A, Cashman K, Beckett F (2020) The importance of grain size and shape in controlling the dispersion of the Vedde cryptotephra. J. Quartern. Sci. 35:175-85

Schipper CI, Castro JM, Tuffen H, James MR, How P (2013) Shallow vent architecture during hybrid explosiveeffusive activity at Cordón Caulle (Chile, 2011-12): evidence from direct observations and pyroclast textures. J Volcanol Geotherm Res 262:25-37

Schmith J, Höskuldsson Á, Holm PM (2017) Grain shape of basaltic ash populations: implications for fragmentation. Bull. Volc. 79:article 14

Schmith J, Höskuldsson Á, Holm PM, Larsen G (2018) Large explosive basaltic eruptions at Katla volcano, Iceland: Fragmentation, grain size and eruption dynamics. J. Volcanol. Geotherm. Res. 354:140-152

Schumacher R., Schmincke, HU (1995) Models for the origin of accretionary lapilli. Bull. Volc. 56:626-639

Shea T, Houghton BF, Gurioli L, Cashman KV, Hammer JE, Hobden BJ, Stovall W, Carey R (2009) SEM image processing with Photoshop. Report published in support of the Fast Object Analysis and Measurement System (FOAMS) program: http://www2.hawaii.edu/ tshea/foams/methodsimrec.htm 
Shea T, Houghton BF, Gurioli L, Cashman KV, Hammer JE, Hobden BJ (2010) Textural studies of vesicles in volcanic rocks: an integrated methodology. J. Volcanol. Geotherm. Res. 190:271-289

Shimano T, Nishimura T, Chiga N, Shibasaki Y, Iguchi M, Miki D, Yokoo A (2013) Development of an automatic volcanic ash sampling apparatus for active volcanoes. Bull. Volc. 75 :article 73

Sparks RSJ, Wilson L, Sigurdsson H (1981) The pyroclastic deposits of the 1875 eruption of Askja, Iceland. Philosophical Transactions of the Royal Society of London. Series A, Mathematical and Physical Sciences 299:241-273

Suda Y, Grebennikov AV, Kuzmin YV, Glascock MD, Wada K, Ferguson JR, Kim JC, et al. (2018) Inter-laboratory validation of the WDXRF, EDXRF, ICP-MS, NAA and PGAA analytical techniques and geochemical characterisation of obsidian sources in northeast Hokkaido Island, Japan. Journal of Archaeological Science: Reports 17:379-392

Sulpizio R, Cioni R, Di Vito MA, Mele D, Bonasia R, Dellino P (2010) The Pomici di Avellino eruption of SommaVesuvius (3.9 ka bp). Part I: stratigraphy, compositional variability and eruptive dynamics. Bull. Volc. 72:539-558

Suzuki Y, Nagai M, Maeno F, Yasuda A, Hokanishi N, Shimano T, Ichihara M, Kaneko T, Nakada S (2013) Precursory activity and evolution of the 2011 eruption of Shinmoedake in Kirishima volcano - insights from ash samples. Earth, Planets and Space 65:11

Swanson D, Wooten K, Orr T (2009) Buckets of ash track tephra flux from Halema'uma'u crater, Hawai'i. Eos, Transactions American Geophysical Union 90:427-427

Szramek L, Gardner JE, Hort M (2010) Cooling-induced crystallization of microlite crystals in two basaltic pumice clasts. American Mineralogist 95:503-509

Taddeucci J, Palladino DM (2002) Particle size-density relationships in pyroclastic deposits: inferences for emplacement processes. Bull. Volc. 64:273-284

Taddeucci J, Pompilio M, Scarlato P (2002) Monitoring the explosive activity of the July-August 2001 eruption of Mt. Etna (Italy) by ash characterization. Geophys. Res. Lett. 29:71-71-71-74

Taddeucci J, Pompilio M, Scarlato P (2004) Conduit processes during the July-August 2001 explosive activity of Mt. Etna (Italy): inferences from glass chemistry and crystal size distribution of ash particles. J. Volcanol. Geotherm. Res. 137:33-54

Thivet S, Gurioli L, Di Muro A, et al. (2020a) Evidences of plug pressurization enhancing magma fragmentation during the September 2016 basaltic eruption at Piton de la Fournaise (La Réunion Island, France). Geochemistry, Geophysics, Geosystems 21:1-30

Thivet S, Gurioli L, Di Muro A (2020b) Basaltic dyke eruptions at Piton de La Fournaise: characterization of the eruptive products with implications for reservoir conditions, conduit processes and eruptive dynamics. Contrib. Mineral. Petrol. 175:article 26

Thivet S, Gurioli L., Di Muro A, Eychenne J, Besson P, Nedelec J-M (2020c) Variability of ash deposits at Piton de la Fournaise (La Reunion Island): insights into fragmentation processes at basaltic shield volcanoes. Bull. Volc. 82:article 63

Thivet S, Harris AJL, Gurioli L, Bani P, Barnie T, Bombrun M, Marchett E (2021), Multi-parametric field experiment links explosive activity and persistent degassing at Stromboli. Front. Earth Sci., DOI $10.3389 /$ feart.2021.669661

Valentine GA (2012) Shallow plumbing systems for smallvolume basaltic volcanoes, 2: Evidence from crustal xenoliths at scoria cones and maars. J. Volcanol. Geotherm. Res. 223-224:47-63

Valentine GA, Groves KR (1996) Entrainment of country rock during basaltic eruptions of the Lucero volcanic field, New Mexico. J. Geol. 104:71-90

Valentine GA, White JDL, Ross P-S, Graettinger AH, Sonder I (2017) Updates to concepts on phreatomagmatic maardiatremes and their pyroclastic deposits. Frontiers in Earth Science, DOI 10.3389/feart.2017.00068

Verolino A, White JDL, Dürig T, Cappuccio F (2019) Black Point - Pyroclasts of a Surtseyan eruption show no change during edifice growth to the surface from $100 \mathrm{~m}$ water depth. J. Volcanol. Geotherm. Res. 384:85-102

Vonlanthen P, Rausch J, Ketcham RA, Putlitz B, Baumgartner LP, Grobéty B (2015) High-resolution 3D analyses of the shape and internal constituents of small volcanic ash particles: The contribution of SEM micro-computed tomography (SEM micro-CT). J. Volcanol. Geotherm. Res. 293:1-12

Walker GPL (1971) Grain-size characteristics of pyroclastic deposits. J Geol 79:696-714

Walker GPL (1973) Explosive volcanic eruptions: a new classification scheme. Geologische Rundschau 62:431446

Walker GPL (1981) Plinian eruptions and their products. Bull. Volc. 44:223-240

Webster JD, Burt DM, Aguillon RA (1996) Volatile and lithophile trace-element geochemistry of Mexican tin rhyolite magmas deduced from melt inclusions. Geochimica et Cosmochimica Acta 60:3267-3283

Wohletz KH (1983a) Mechanisms of hydrovolcanic pyroclast formation: grain-size, scanning electron microscopy, and experimental studies. J. Volcanol. Geotherm. Res. 17:3163

Wohletz KH (1983b) Chemical and textural features of pyroclasts from hydrovolcanic eruption sequences. Los Alamos National Laboratory, report LA-UR-83-250

Wohletz KH (1986) Explosive magma-water interactions: Thermodynamics, explosion mechanisms, and field studies. Bull. Volc. 48:245-264

Wohletz K, Krinsley D (1978) Scanning electron microscopy of basaltic hydromagmatic ash. Los Alamos National Laboratory, report LA-UR-82-1433

Wohletz KH, Sheridan MF, Brown WK (1989) Particle size distribution and sequential fragmentation/transport theory applied to volcanic ash. J. Geophys. Res. 94:15 70315721

Wohletz K, Orsi G, de Vita S (1995) Eruptive mechanisms of the Neapolitan Yellow Tuff interpreted from stratigraphic, chemical, and granulometric data. J. Volcanol. Geotherm. Res. 67:263-290

White JDL (1991) Maar-diatreme phreatomagmatism at Hopi Buttes, Navajo Nation (Arizona), USA. Bull. Volc. $53: 239-258$

White JDL (1996a) Impure coolants and interaction dynamics of phreatomagmatic eruptions. J. Volcanol. Geotherm. Res. $74: 155-170$

White JDL (1996b) Pre-emergent construction of a lacustrine basaltic volcano, Pahvant Butte, Utah. Bull. Volc. 58:249262

White JDL, Houghton BF (2006) Primary volcaniclastic rocks. Geology 34:677-680

White JDL, Ross P-S (2011) Maar-diatreme volcanoes: a review. J. Volcanol. Geotherm. Res. 201:1-29

White JDL, Valentine GA (2016) Magmatic versus phreatomagmatic fragmentation: absence of evidence is not evidence of absence. Geosphere 12:1478-1488

Yoshimoto M, Shimano T, Nakada S, Koyama E, Tsuji H, Iida A, Kurokawa M, Okayama Y, Nonaka M, Kaneko T, Hoshizumi H, Ishizuka Y, Furukawa R, Nogami K, 
Onizawa S, Niihori K, Sugimoto T, Nagai M (2005) Mass estimation and characteristics of ejecta from the 2004 eruption of Asama volcano. Bull Volc. Soc. Jpn 50:519533 (in Japanese with English abstract)

Zimanowski B, Büttner R, Lorenz V, Häfele H-G (1997) Fragmentation of basaltic melt in the course of explosive volcanism. J. Geophys. Res. 102:803-814
Zimanowski B, Büttner R, Delino P, White JDL, Wohletz K (2015) Magma-water interaction and phreatomagmatic fragmentation. In: Sigurdsson H, Houghton B, McNutt SR, Rymer H, Stix J (eds) Encyclopedia of Volcanoes, Second Edition. Academic Press, London, pp 473-484 
Tables

Table 1. Correspondence between the $\phi$ scale and $\mathrm{mm}$, for half- $\phi$ sieving columns.

\begin{tabular}{cccc}
\hline Passing through $(\phi)$ & Retaining sieve $(\phi)$ & Size range $(\mathrm{mm})$ & Grain size term* \\
\hline & & $>64$ & Block/bomb \\
-6 & -5.5 & $64-45.3$ & Coarse lapilli \\
-5.5 & -5 & $45.3-32$ & Coarse lapilli \\
-5 & -4.5 & $32-22.6$ & Coarse lapilli \\
-4.5 & -4 & $22.6-16$ & Coarse lapilli \\
-4 & -3.5 & $16-11.3$ & Medium lapilli \\
-3.5 & -3 & $11.3-8$ & Medium lapilli \\
-3 & -2.5 & $8-5.7$ & Medium lapilli \\
$\mathbf{- 2 . 5}$ & $-\mathbf{2}$ & $\mathbf{5 . 7 - 4}$ & Medium lapilli \\
-2 & -1.5 & $4-2.8$ & Fine lapilli \\
-1.5 & -1 & $2.8-2$ & Fine lapilli \\
-1 & -0.5 & $2-1.4$ & Very coarse ash \\
-0.5 & 0 & $1.4-1$ & Very coarse ash \\
0 & +0.5 & $1-0.71$ & Coarse ash \\
$+\mathbf{0 . 5}$ & $+\mathbf{1}$ & $\mathbf{0 . 7 1 - 0 . 5}$ & Coarse ash \\
+1 & +1.5 & $0.5-0.35$ & Medium ash \\
+1.5 & +2 & $0.35-0.25$ & Medium ash \\
+2 & +2.5 & $0.25-0.18$ & Fine ash \\
+2.5 & +3 & $0.18-0.125$ & Fine ash \\
+3 & +3.5 & $0.125-0.088$ & Very fine ash \\
$+\mathbf{3 . 5}$ & $+\mathbf{4}$ & $\mathbf{0 . 0 8 8}-\mathbf{0 . 0 6 3}$ & Very fine ash \\
& & $<0.063$ & Extremely fine ash \\
\hline
\end{tabular}

* White and Houghton (2006) 
Table 2: Comparison of three particle mounting methods for SEM imaging

\begin{tabular}{|c|c|c|c|}
\hline & $\begin{array}{l}\text { 2D particle cross-section } \\
\text { (polished epoxy grain mount) }\end{array}$ & $\begin{array}{l}\text { 2D projected silhouette (carbon tape grain } \\
\text { mount) }\end{array}$ & Dual mounting \\
\hline Pros & $\begin{array}{l}\text { Provides information about } \\
\text { particle morphology and } \\
\text { internal textures } \\
\text { - Can also be used to } \\
\text { determine groundmass and } \\
\text { phenocryst chemistry }\end{array}$ & $\begin{array}{l}\text { Silhouettes can be used in various } \\
\text { morphological parameter systems } \\
\text { and compared to published studies, } \\
\text { if the same size fraction is used } \\
\text { Particle morphology can be directly } \\
\text { linked with particle surface features, } \\
\text { using the same grains } \\
\text { Full particle diameter and particle } \\
\text { complexity captured }\end{array}$ & $\begin{array}{l}\text { - Full suite of parameters can } \\
\text { be determined (basic } \\
\text { componentry, morphology, } \\
\text { internal textures, surface } \\
\text { features) } \\
\text { - Assurance that only glassy } \\
\text { (or similar) juvenile } \\
\text { particles are actually used } \\
\text { for morphological } \\
\text { parameters and surface } \\
\text { features }\end{array}$ \\
\hline Cons & $\begin{array}{l}\text { Possible particle edge } \\
\text { modification due to sample } \\
\text { preparation (grinding and } \\
\text { polishing must be done very } \\
\text { carefully) } \\
\text { - No direct information of } \\
\text { original particle size (due to } \\
\text { sectioning) } \\
\text { User must screen out particle } \\
\text { cross-sections that are too } \\
\text { small to be representative } \\
\text { Highly inequant particles } \\
\text { (plates, hairs) may be } \\
\text { systematically } \\
\text { underrepresented }\end{array}$ & $\begin{array}{l}\text { - No quantification of crystals and } \\
\text { bubbles } \\
\text { Avoiding lithics and free crystals } \\
\text { may be difficult (no view of the } \\
\text { grain interior) } \\
\text { Depending on the depth of field } \\
\text { of the imaging system used, care } \\
\text { has to be taken to get the } \\
\text { silhouette into sharp focus } \\
\text { (possible for the }+4 \phi \text { fraction, } \\
\text { but can be a problem for coarser } \\
\text { grains) }\end{array}$ & $\begin{array}{l}\text { More work than a single } \\
\text { mounting technique used } \\
\text { alone }\end{array}$ \\
\hline $\begin{array}{l}\text { Adopted } \\
\text { for }\end{array}$ & $0.71-0.5 \mathrm{~mm}(+0.5$ to $+1 \phi)$ & $\begin{array}{l}88-63 \mu \mathrm{m}(+3.5 \text { to }+4 \phi), \\
\text { as part of dual mounting }\end{array}$ & $88-63 \mu \mathrm{m}(+3.5$ to $+4 \phi)$ \\
\hline
\end{tabular}




\section{Figures}

\section{IAIVUAKU D I ERO UINLY}

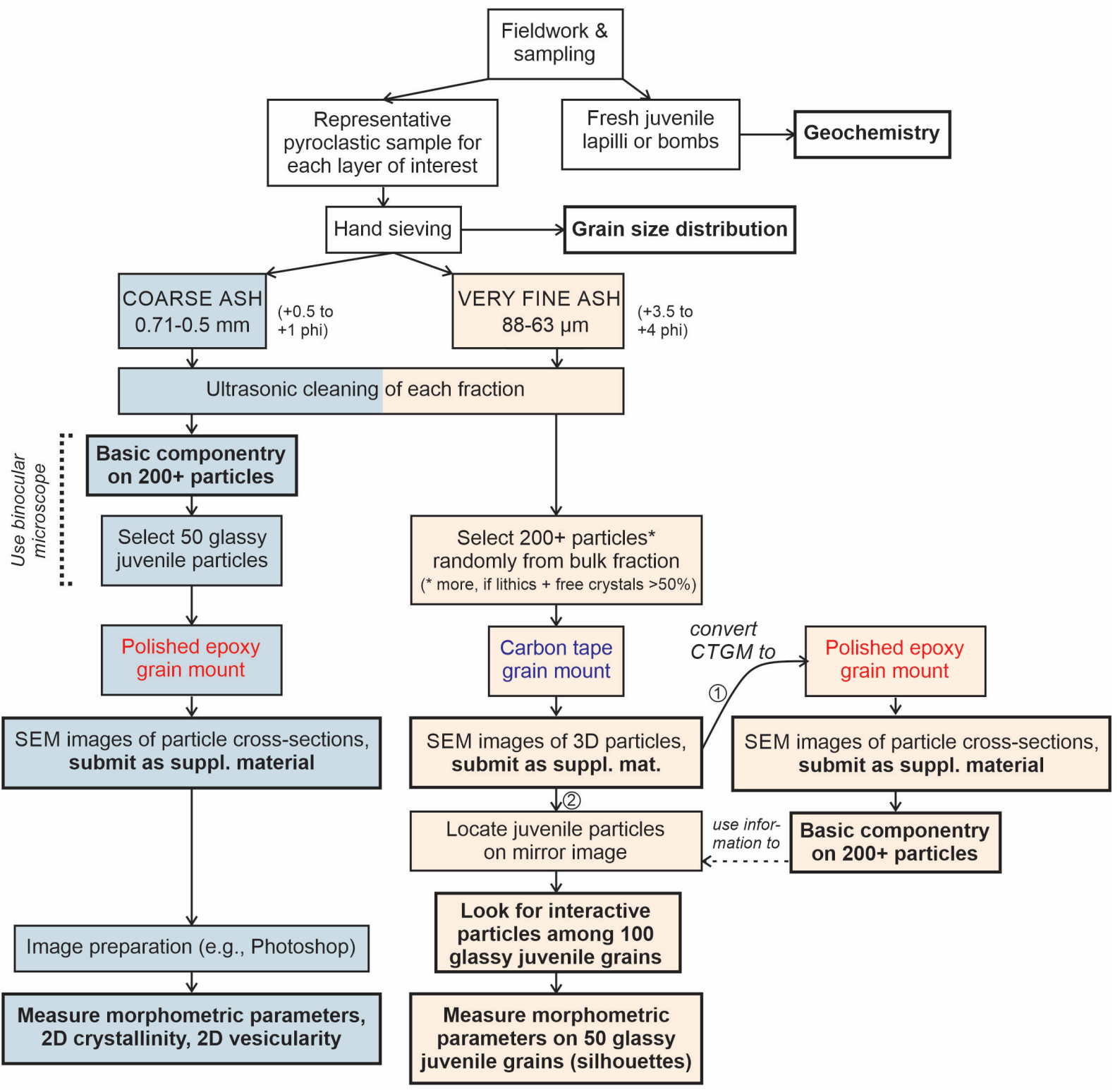

Fig. 1. Flowchart of the steps needed to analyze juvenile pyroclasts for comparative fragmentation studies, showing standard steps only. Bold items are outputs. A separate sample of "fresh juvenile lapilli or bombs" may not be needed, if geochemistry is done through micro-analysis on the coarse ash fraction (see text for a full explanation). 


\section{STANDARD AND RECOMMENDED STEPS}

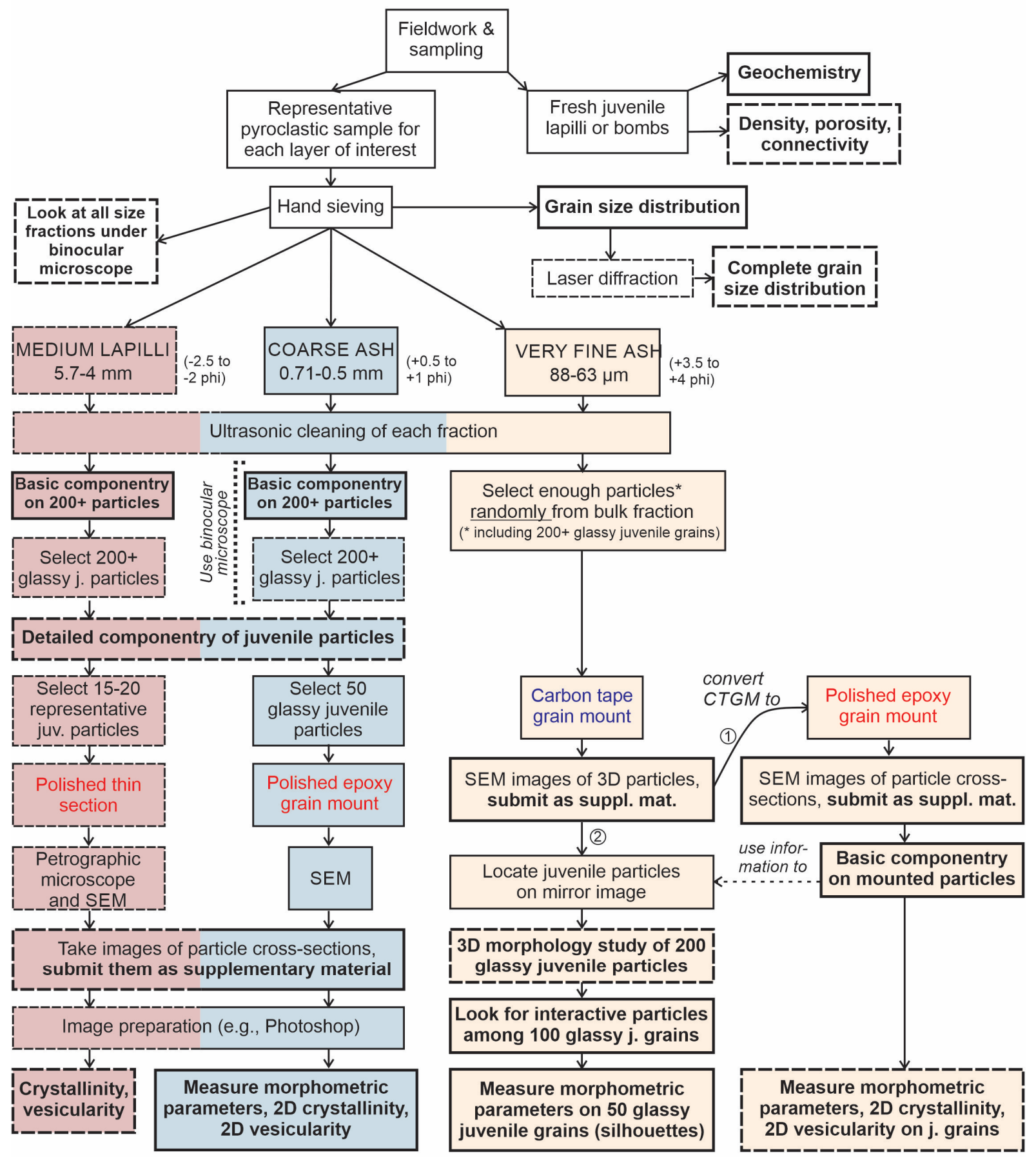

Fig. 2. Flowchart of the steps needed to analyze juvenile pyroclasts for comparative fragmentation studies, showing standard steps (continuous lines) and recommended steps (dashed lines). Bold items are outputs. 


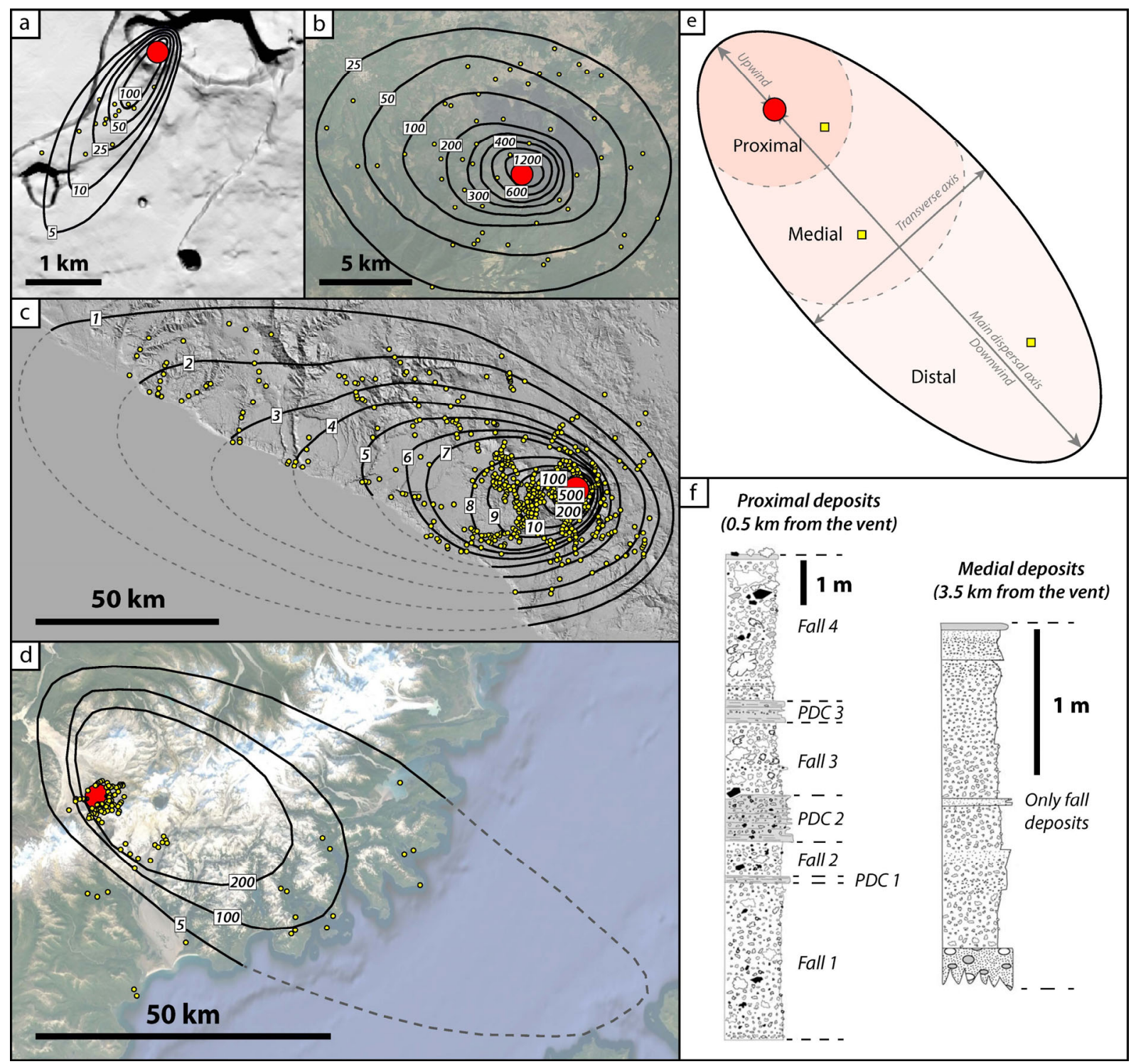

Fig. 3. Characteristics of fallout deposits from different eruptive styles. (a)-(b)-(c)-(d) Isopach maps from (a) Hawaiian fountaining activity, episode 4-8 of the 1959 Kīlauea Iki eruption, Hawaii, USA (modified from Mueller et al. 2018); (b) violent Strombolian monogenic activity, 1952 Paracutín eruption, Mexico (modified from Pioli et al. 2008); (c) Plinian activity, 1600 CE Huaynaputina eruption, Peru (modified from Prival et al. 2019). (d) Plinan activity, 1912 Novarupta eruption, Alaska, USA (modified from Houghton et al. 2004). Contours are in cm, eruptive vents and thickness measurements are represented by the large red and small yellow circles, respectively. (e) Sketch of the different spatial zones that can be identified in a fallout field. The proximal, medial and distal zone positions vary depending on the intensity of the eruptions: the proximal zone reaches around $0.5 \mathrm{~km}$ from the vent for the 1959 Killauea Iki eruption but around $50 \mathrm{~km}$ for the 1600 CE Huaynaputina eruption. Yellow squares are hypothetical sampling sites. (f) Complex stratigraphic logs of the 1912 Novarupta Plinian deposits showing the potential spatial and temporal variations of the deposit characteristics (modified from Houghton et al. 2004). 

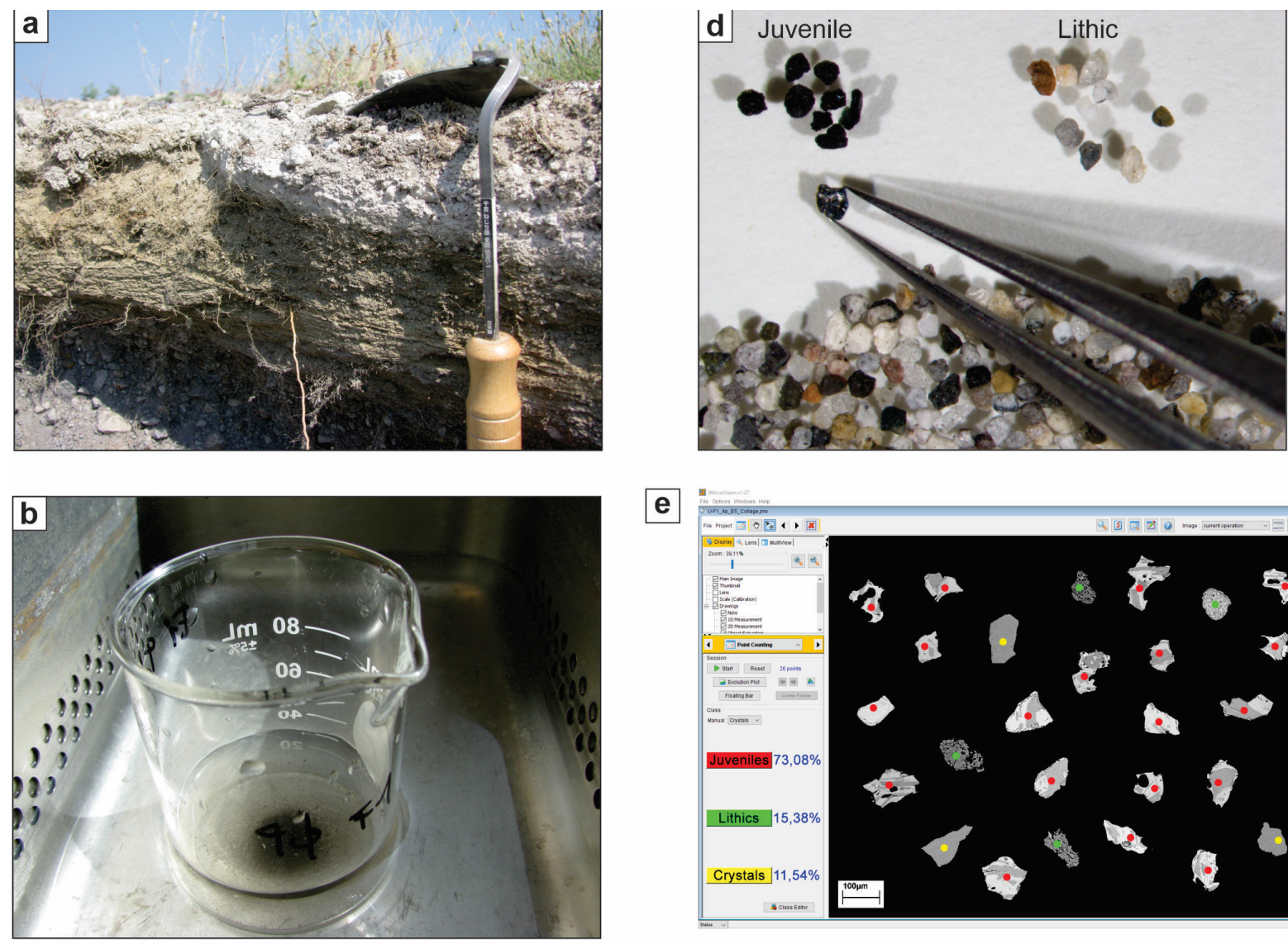

$\mathbf{e}$
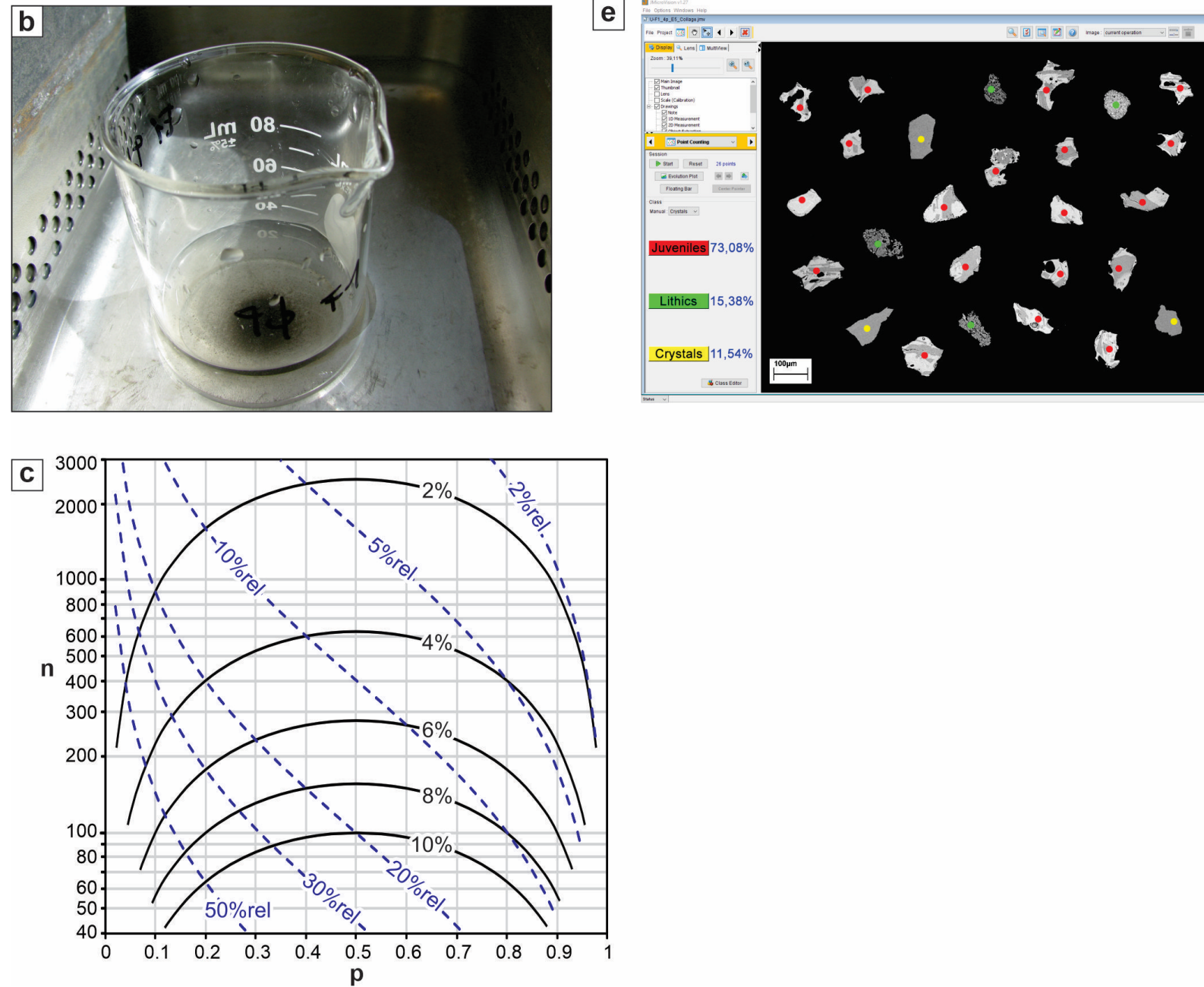

Fig. 4. Field work, ultrasonic cleaning, and basic componentry. (a) The Japanese garden tool often used for cleaning the face during field work. The brown and grey pyroclastic deposits are products of the May 18, 1980 lateral blast at Mont St. Helens, USA. (b) Ultrasonic cleaning of a size fraction in distilled water. (c) Simplified version of the error chart developed by van der Plas and Tobi (1965) for petrographic point counting. ' $p$ ' is the abundance of a component and $n$ is the number of points to be counted. The black continuous curves represent two standard deviations $(2 \sigma)$. For example, the $4 \%$ absolute error curve intersects the $\mathrm{p}=0.2$ vertical line at $\mathrm{n}=400$. This means that a component with a real abundance of $20 \%$ in the sample will be measured between $16 \%(\mathrm{p}-2 \sigma)$ and $24 \%(\mathrm{p}+2 \sigma)$ abundance, $95 \%$ of the time, if 400 points are counted. The blue dashed curves are relative errors $(2 \sigma / \mathrm{p})$. For example, if a $20 \%$ relative error is acceptable, and $p=0.2$, then $n$ must equal 400. (d) Componentry of the coarse ash fraction with tweezers under the binocular microscope. (e) Componentry of the very fine ash fraction using a polished epoxy grain mount, SEM images and manual point counting in JMicrovision. The colored dots have been enlarged for better visibility. 


\section{Carbon tape grain mount}
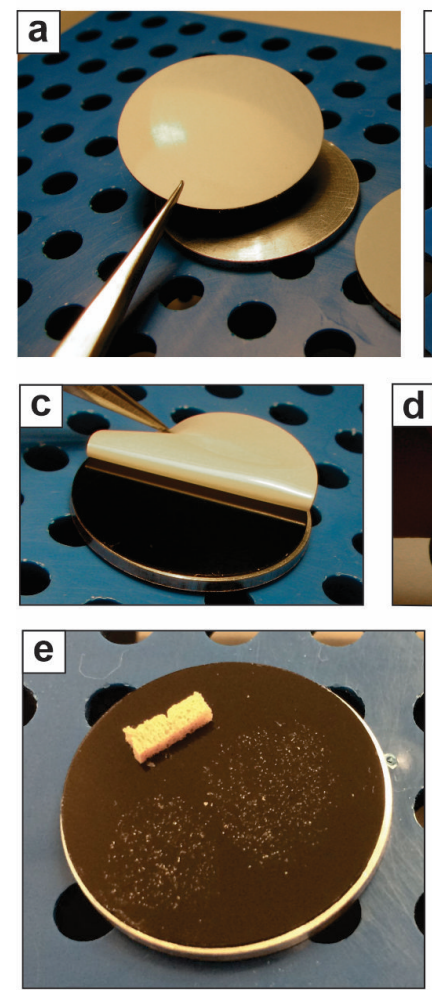

\section{Polished epoxy grain mount}
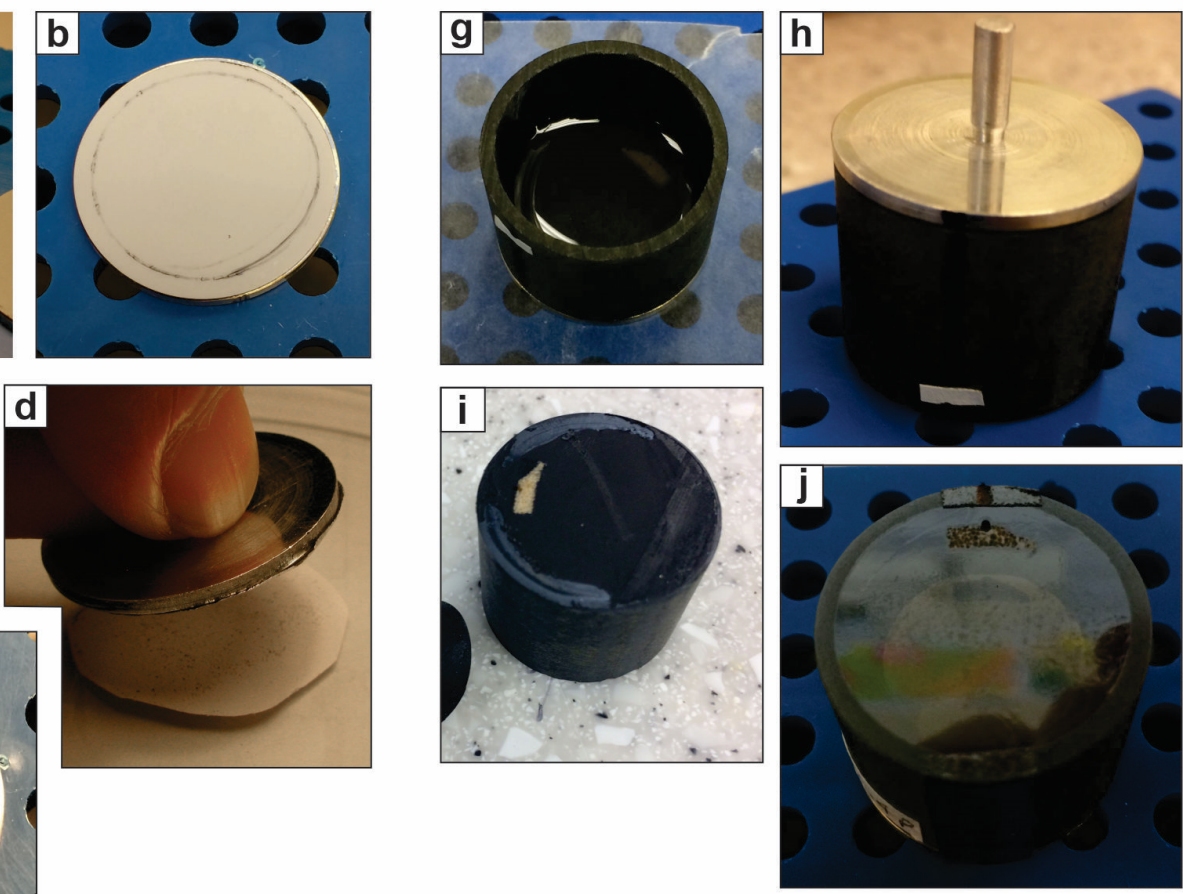

\section{SEM imaging of both states}
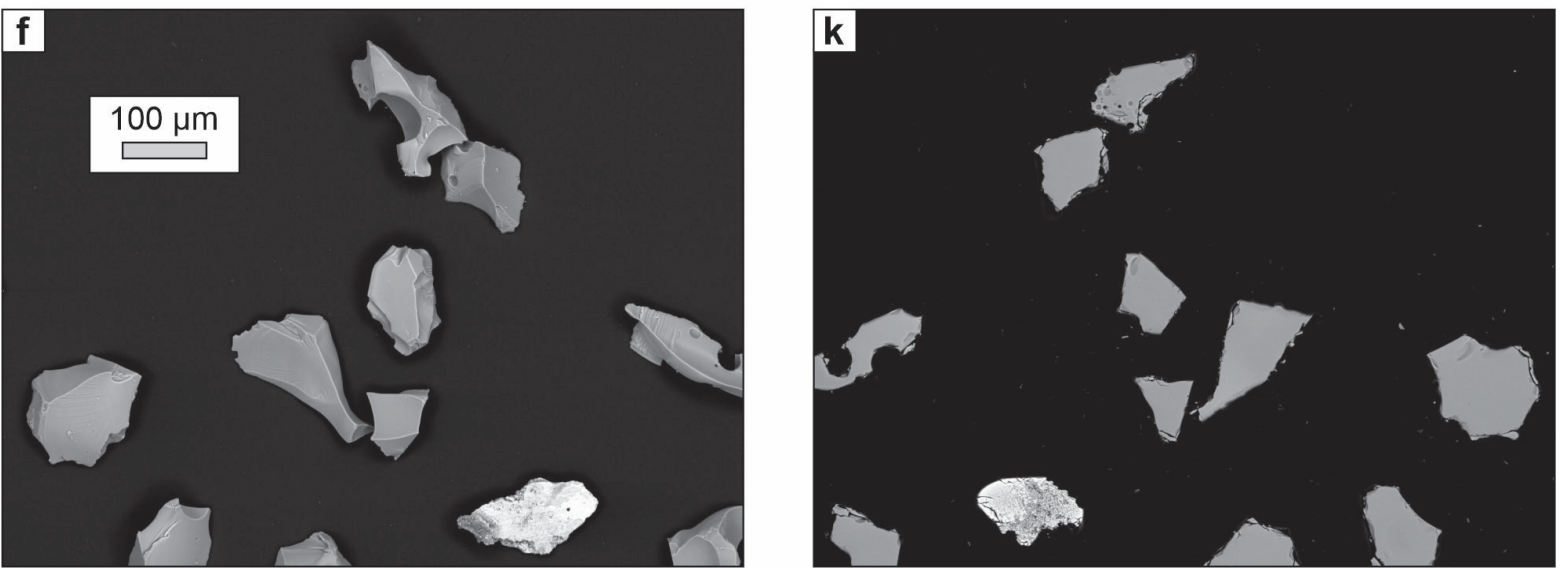

Fig. 5. Dual mounting procedure for the very fine ash fraction, i.e. $88-63 \mu \mathrm{m}(+3.5$ to $+4 \phi)$ : (a)-(e) carbon tape grain mount; (g)-(j) polished epoxy grain mount; (f)\&(k) SEM images in each state. (a) Placing the carbon tape on the aluminum stub. (b) Drawing a smaller circle on the non-stick paper. (c) Peeling off the non-stick paper. (d) Spreading ash grains on the non-stick paper and very gently picking them up with the upside-down aluminum stub covered in carbon tape. (e) A finished carbon tape grain mount where particles have been transferred with the thumb method instead, with two side-by-side applications. A piece of cork is used for a horizontal line reference. The only step left is depositing a thin film or carbon before imaging. (f) SEM-BSE image of the 3D particles, to be used for measuring morphometric parameters and inspecting particle surface features (to search for interactive ones). (g) After the ring form is applied, epoxy resin is poured. (h) The resin is cured and the cured assembly can be turned upside down. This becomes the new 'up' direction'. (i) Removing the aluminum stub and carbon tape, before cleaning, grinding and polishing. (j) The finished polished epoxy grain mount after covering with a thin film of carbon. (k) SEM-BSE image of the particle cross-sections, to be used for basic componentry. This is the mirror image from (f). The grinding and polishing has been done quickly for demonstration purposes, so this image is only usable for basic componentry. 


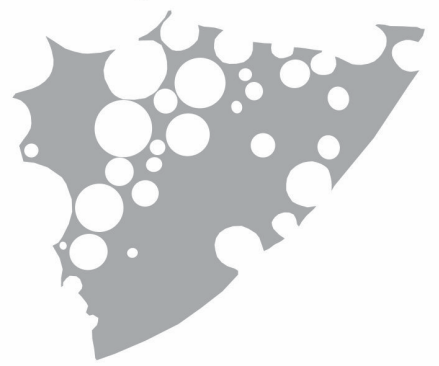

Note: for particle cross-sections, internal vesicles must be filled

first before measuring any morphometric parameters

b

\section{Best fitting ellipse}

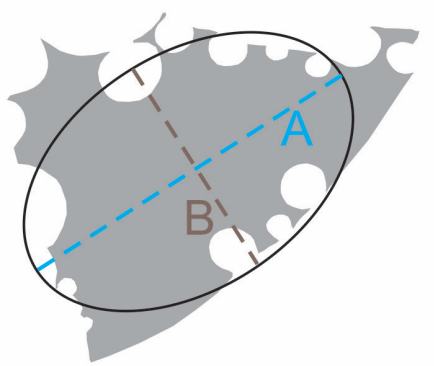

\section{c Bounding box and circle of equivalent area}

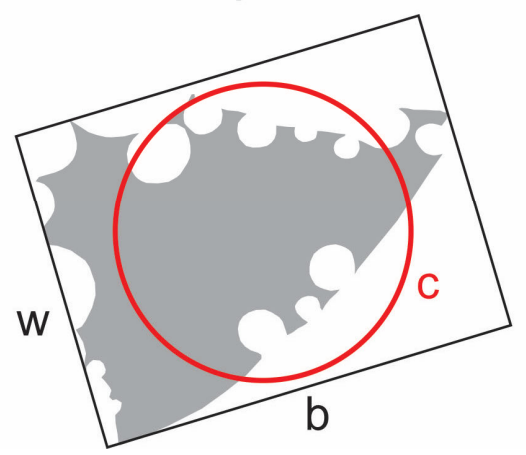

Convex hull

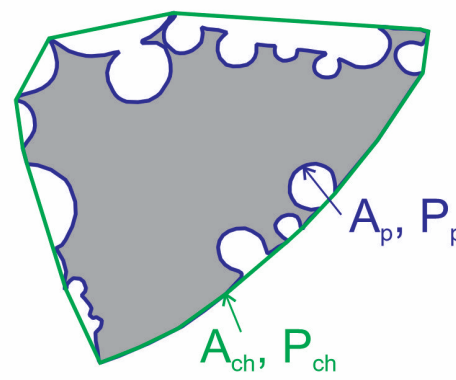

$$
\begin{aligned}
& \text { Maximum (a) and } \\
& \text { mean (m) intercept }
\end{aligned}
$$

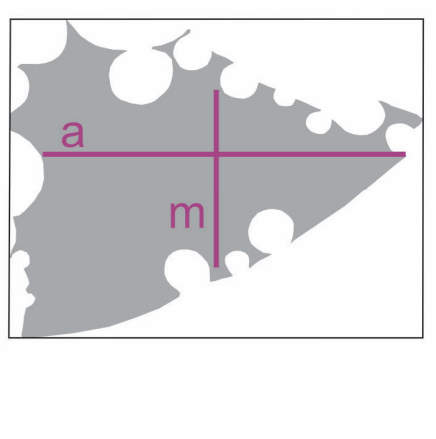

\section{Parameters}

Axial ratio $=\mathrm{B} / \mathrm{A}$

Solidity $=A_{p} / A_{c h}$

Convexity $=P_{c h} / P_{p}$

\section{Parameters}

Circularity $=P_{p} / c$

Rectangularity $=\mathrm{P}_{\mathrm{p}} /(2 \mathrm{~b}+2 \mathrm{w})$

Compactness $=A_{p} /\left(b^{*} w\right)$

Elongation $=\mathrm{a} / \mathrm{m}$

Fig. 6. Definitions of the standard morphometric parameters, modified from Liu et al. (2015a) and Dürig et al. (2019). (a) The original particle, before infilling the internal vesicles. Note that for particle cross-sections, internal vesicles must be infilled before morphometric parameters are measured. (b) The three main parameters suggested by Liu et al. (2015a): axial ratio (sensitive to particle elongation), solidity (a measure of morphological roughness, sensitive to largescale concavities) and convexity (a measure of textural roughness, sensitive to small-scale concavities or protrusions). $\mathrm{A}$ and $\mathrm{B}$ are the major and minor axes of the best-fitting ellipse, which has the same area, orientation and centroid as the original particle. $A_{p}$ and $P_{p}$ are the area and perimeter of the particle. $A_{c h}$ and $P_{c h}$ are the area and perimeter of the convex hull, which is like a rubber band enveloping the particle (ImageJ User Guide version 1.46r). (c) The IPA parameters of Dellino and La Volpe (1996): circularity, rectangularity, compactness and elongation. 'c' is the perimeter of a circle with area $A_{p}$. W and $b$ are the width and breadth of the minimum area bounding box. Note that this box is not necessarily parallel to the sides of the original image. $a$ is the maximum intercept, i.e. the longest segment inside a particle, parallel to the long side of the bounding rectangle. Finally $\mathrm{m}$ is the mean intercept, perpendicular to a. Parameters a and $\mathrm{m}$ are measured after the particle is rotated to the long axis of the minimum bounding box. 

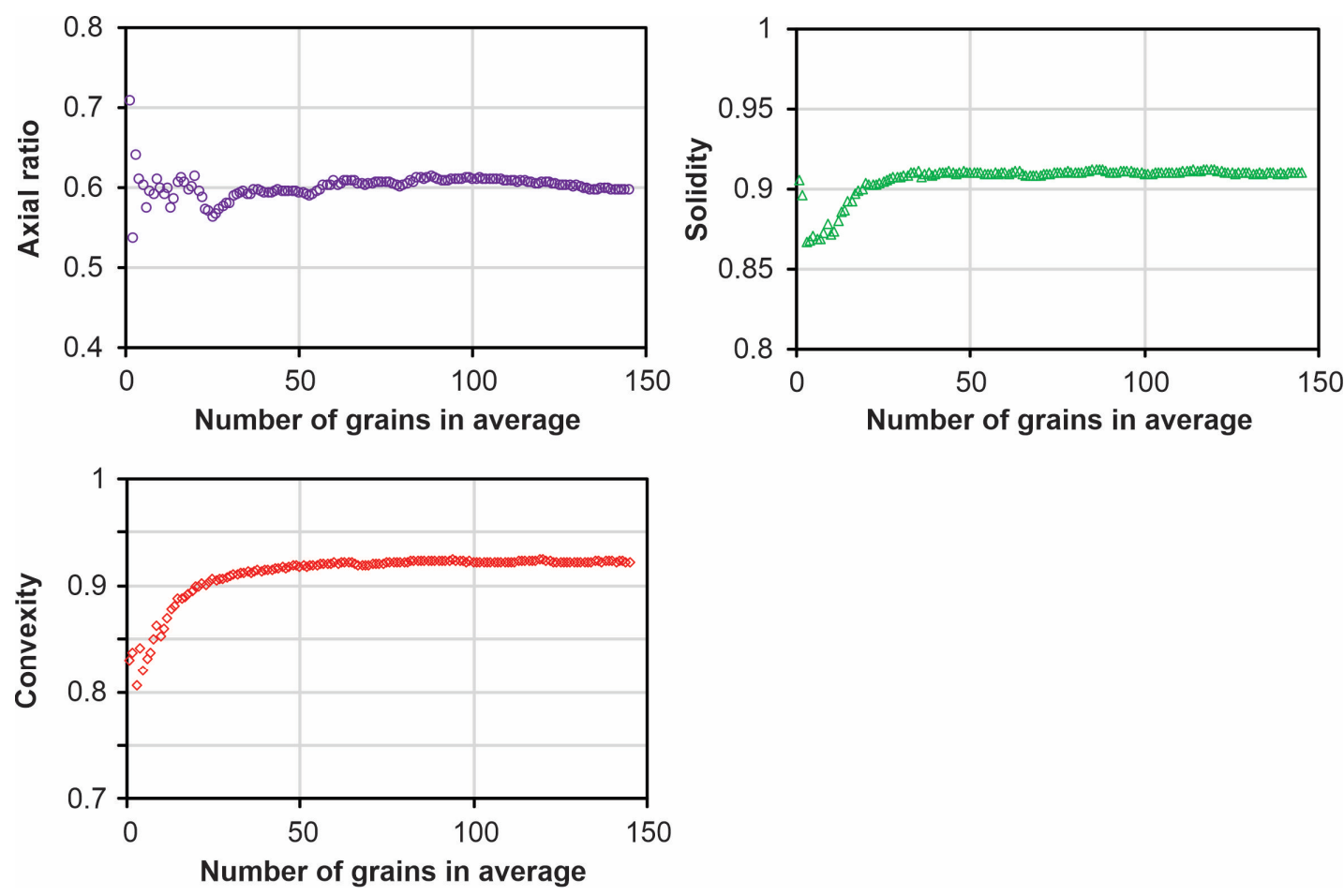

Fig. 7. Stability test for morphology measurements of particle silhouettes, using an ash sample (HVR159, 125-63 $\mu \mathrm{m}$ or +3 to $+4 \phi$ ) from the 2012 eruption of Havre volcano (Kermadec Arc). 


\section{Mafic}
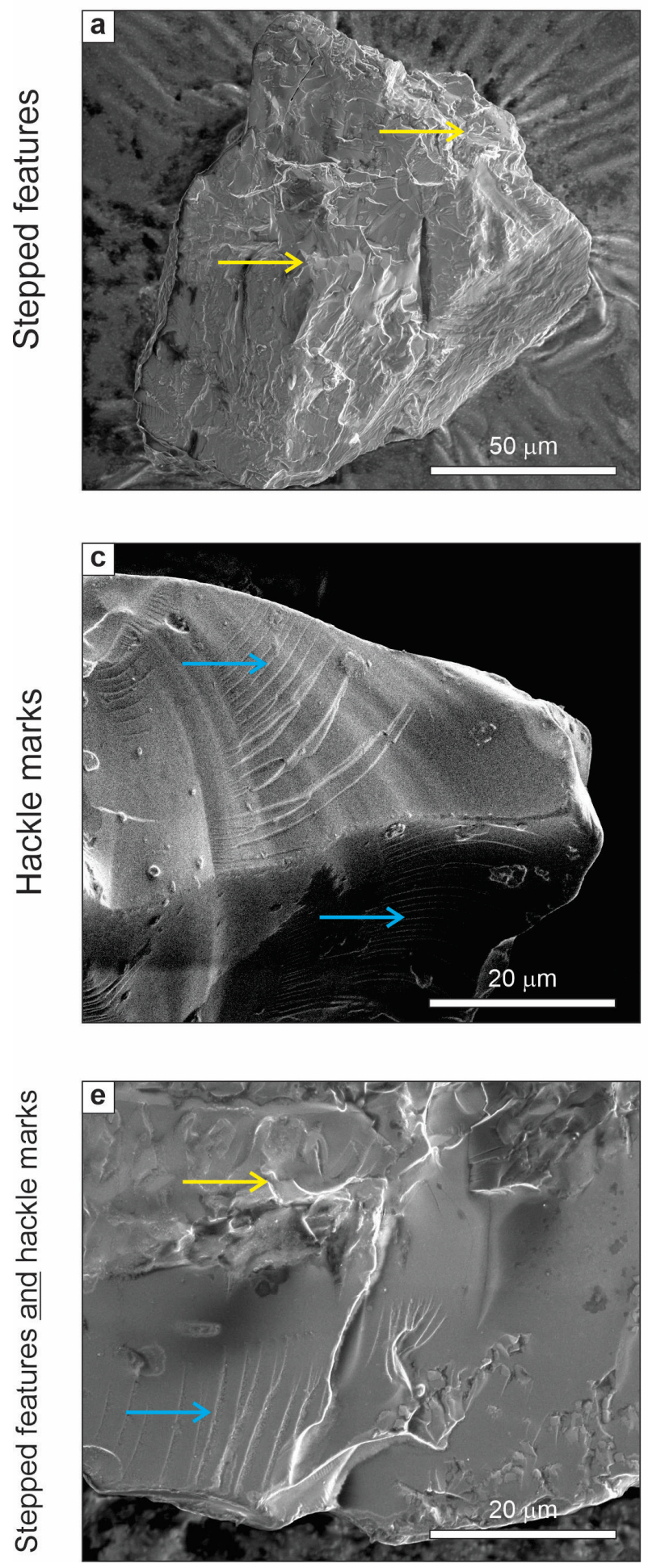

\section{Felsic}
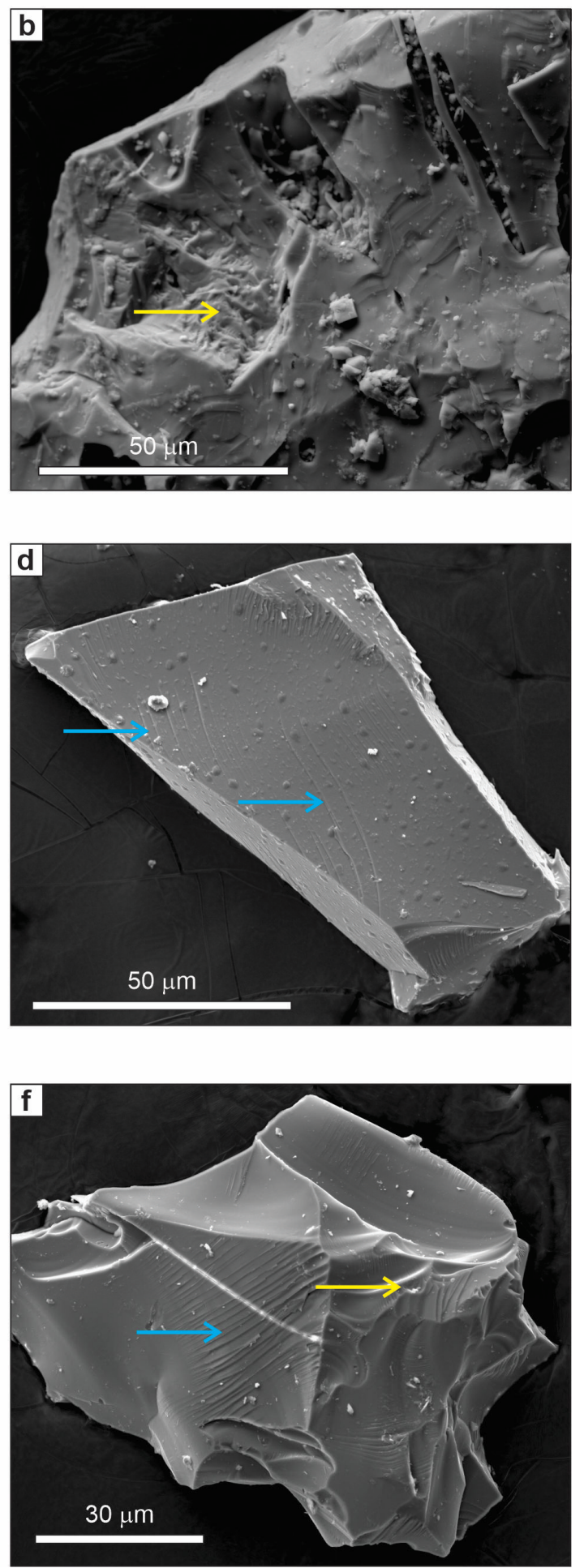

Fig. 8. Secondary electron SEM images of stepped features and hackle marks. (a)-(c)-(e) are for mafic magma and (b)(d)-(f) are for felsic magma. (a)-(b) Stepped features (yellow arrows). (c)-(d) Hackle marks (blue arrows). (e)-(f) Stepped features (yellow arrows) and hackle marks (blue arrows). All particles were created by fuel coolant interaction during experiments at the University of Würzburg, except (b) which is natural ash from the Havre 2012 eruption. 
Mafic
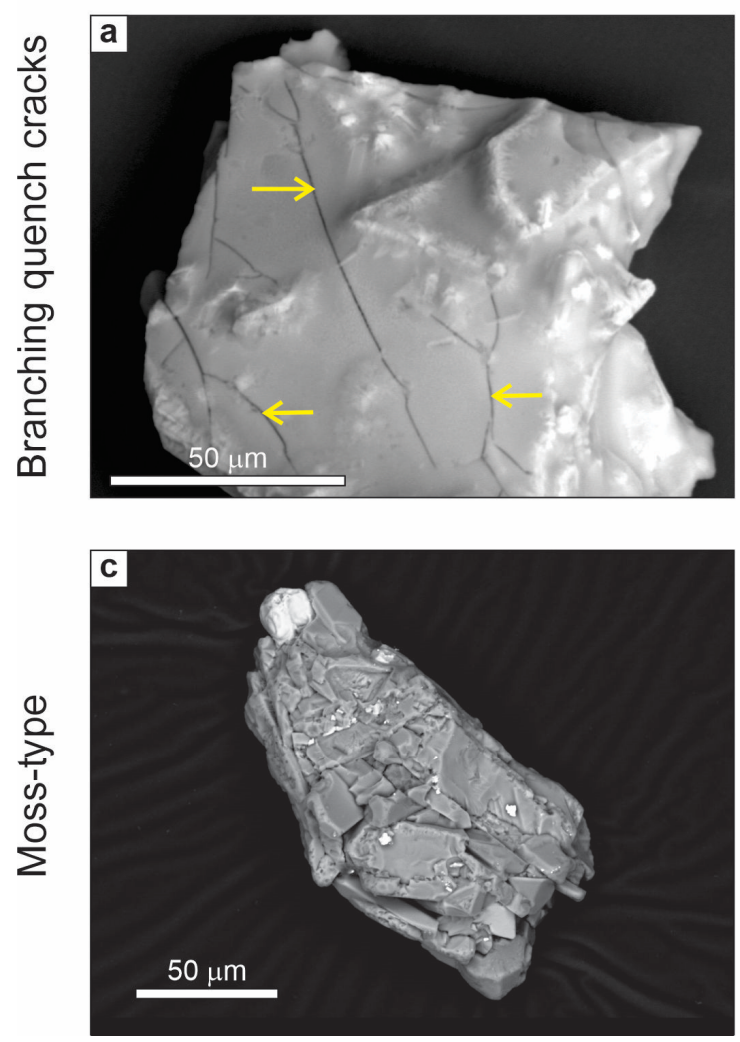

Felsic

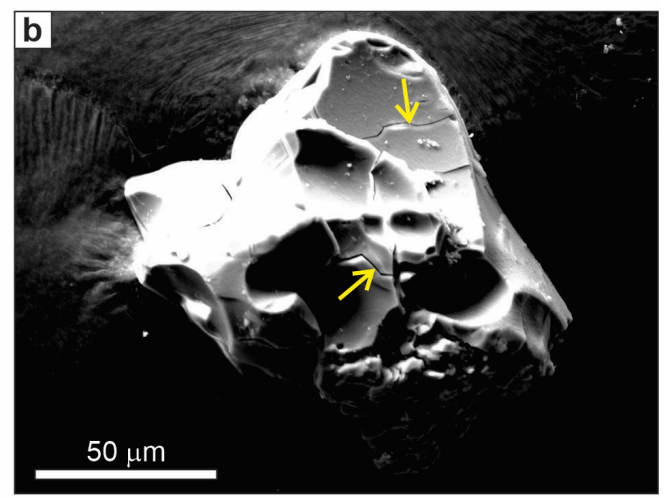

Fig. 9. SEM images of two types of interactive particles. (a) Branching quench cracks (arrows) in a natural mafic juvenile pyroclast from Ukinrek east maar, Alaska. (b) Branching quench cracks (arrows) in an experimental felsic pyroclast created during an induced fuel-coolant interaction experiment (Dürig et al. 2020b). (c) Moss-type particle created during a MFCI experiment with mafic magma at the University of Würzburg. First two images in secondary electron mode and third one in BSE mode. 


\section{Online resource 1: Recommended and optional steps}

The proposed standardized methodology for the analysis of juvenile particles, to be used in comparative studies of primary magma fragmentation, contains standard, recommended and optional steps. The paper describes the standard steps (workflow: Fig. 1), whereas this supplementary document describes the recommended steps (workflow: Fig. 2) and the optional steps (not included on flowcharts). Again, the presentation broadly follows the order of the steps on the flowchart (Fig. 2), from top to bottom and left to right, focusing on the additional recommended steps (boxes with dashed outlines).

\section{Density, porosity, connectivity and permeability measurements}

Lapilli or bombs can be used for several types of density, porosity and permeability measurements. To be complete we also describe similar measurements on ash here.

Dense rock equivalent density (recommended)

Dense rock equivalent (DRE) density is best measured on a several representative lapilli or bomb fragments, which are crushed. The volume of the powders can be precisely measured with gas pycnometers. The DRE density is then deduced by dividing the mass of the powders by their volume (Formenti and Druitt 2003). The DRE density mostly depends on the glass composition and on the crystal phases. Thus, this parameter is important for a global database in order to compare the DRE densities with those given for magma, melt and crystal compositions.

\section{Porosity (recommended)}

Porosity is calculated by comparing the bulk density (including voids) of a sample with the DRE density. The bulk density of a section of lapilli or bomb is measured either using the water immersion technique (Houghton and Wilson 1989; Shea et al. 2010) or using envelope density analyzers (Kawabata et al. 2015). These two techniques show very similar results (Thivet al. 2020a).

The average porosity of a selection of ash particles can also be measured using the water pycnometry method (Eychenne and Le Pennec 2012). The porosity/density range of the ash, lapilli and bombs can thus be compared each other (for different grain sizes) and can be also compared to $2 \mathrm{D}$ or $3 \mathrm{D}$ vesicularity.

\section{Vesicle connectivity (recommended)}

Vesicle connectivity is best measured on bomb fragments and lapilli using gas pycnometers following Formenti and Druitt (2013) and Colombier (2017a) procedures, and can bring insights on vesicle nucleation, growth and coalescence processes that might occur within magma storage and conduit areas, as well as crack formation that might occur during magma fragmentation (Gurioli et al. 2018; Thivet et al. 2020a, 2020b). Thus, vesicle connectivity is an important parameter to measure when dealing with eruptive dynamics and magma fragmentation mechanisms.

\section{Clast permeability (optional)}

Permeability can be measured on bomb and lapilli fragments following the Colombier (2017b) procedure, based for instance on the Takeuchi et al. (2008) experiments. Measuring tephra permeability allows estimation of magma permeability at the fragmentation level, hence this is a key physical parameter to measure the efficiency of gas flow within the magma column and thus allow assessment of overpressure-driven fragmentation mechanisms (Thivet et al. 2020a; Bain et al. 2021).

\section{Grain-size distribution}

Complete grain size analysis (recommended)

Sieving at half $\phi$ steps is part of the standardized methodology, both to obtain grain size information and to extract specific size fractions for the analysis of juvenile pyroclasts. Sieving typically yields the grain size distribution down to $63 \mu \mathrm{m}(+4 \phi)$, and the finer particles go to the 'pan'. If additional resolution at the smallerparticle end of the size distribution is required, the contents of pan and several sieve fractions above it (e.g., up $250 \mu \mathrm{m}$ ) can be recombined and analyzed with laser diffraction techniques (e.g., Dellino and La Volpe 1995; Bonadonna et al. 2011; Dellino et al. 2012; Pardo et al. 2014a; Gaunt et al. 2016; Liu et al. 2017). The laser diffraction technique determines the particle size distribution of a dispersed sample in an aqueous solution through the application of the Mie theory (Riley et al. 2003). Results from all techniques are then carefully combined to produce a complete grain size distribution (e.g., Dellino and La Volpe 1995; Manville et al. 2002; Dellino et al. 2012; Eychenne et al. 2012; Pardo et al. 2014a; Jones et al. 2016; Liu et al. 2017).

The particle size distributions obtained by laser diffraction should be binned to half $\phi$ to be consistent with the sieving data. Assuming that the particle density is constant over the size range analyzed by laser diffraction (reasonable in most deposits, see Eychenne and Le Pennec 2012; Cashman and Rust 2016), the vol. \% particle size distributions obtained by laser diffraction are equivalent to wt.\% distributions. Sieving and laser diffraction wt.\% particle size distributions can be merged by scaling the laser distribution to the mass fraction (wt.\%) finer than $250 \mu \mathrm{m}$ in the original sieved sample (Eychenne et al. 2012).

The overlap between sieving and laser diffraction data over the 250 to $63 \mu \mathrm{m}$ size range can be used to evaluate the agreement between the two methods and refine the quality of fit. Because the two methods rely on fundamentally different measurement techniques, they are sensitive to the nature of the sample and the shape(s) 
of the particles, so can derive different wt.\% values for the same grain size fraction. In case of poor agreement between the sieving and laser diffraction data over the 250 to $63 \mu \mathrm{m}$ size range, an empirical scale factor, minimizing the residual between the wt.\% values obtained between 250 and $63 \mu \mathrm{m}$ by the two methods, can be applied to the laser diffraction data before merging.

\section{Total grain size distribution (optional)}

Total grain size distribution (TGSD) of fallout deposits is important for eruption plume models and can yield insights on primary magma fragmentation and eruption intensity (e.g., Bonadonna and Houghton 2005; Costa et al. 2016; Pioli et al. 2019). This requires obtaining grain size distributions at many (from proximal to distal) sites representative of the full extent of the deposit and combining them in a statistically robust manner (Bonadonna and Houghton 2005; Andronico et al., 2014a; Costa et al. 2016; Pioli et al. 2019). However, since TGSDs require a lot of work and the current workflows focus on juvenile particles, we leave this as a completely optional step.

\section{Familiarization (recommended)}

Once sieving is complete, it is good practice to look at all size fractions under the binocular microscope. We suggest using a binocular microscope with a magnification range up to 60 times or more. This recommended familiarization step will provide qualitative information on componentry (the proportions of different clast types), the shapes and vesicularities of juvenile pyroclasts, etc. Dust adhering to particles may be a hindrance at this stage, and moredetailed observations can be done on the selected size fractions after the ultrasonic cleaning step (see the paper and Fig. 2).

\section{Choice of size fractions: adding medium lapilli}

Reasons for our choice of ash fractions are described in the paper. We add a recommended lapilli size fraction here, which allows us to identify the larger vesicles and crystals (e.g., Gurioli et al. 2015). Note, however, that post-fragmentation expansion is likely to have significantly affected basaltic lapilli (e.g., Fig. 4b in Porritt et al. 2012). Lapilli are commonly used in vesiclepopulation studies for more-felsic compositions (e.g., Gardner et al. 1996), and analysis is thus useful as a tie-in with that body of work.

We consider that it is best to work on the 5.7 to $4 \mathrm{~mm}$ (2.5 to $-2 \phi)$, particles, which are part of the medium lapilli range (White and Houghton 2006; Table 1 in the paper). This keeps the same $\phi$ spacing as between the other selected fractions ( $3 \phi$ units apart; Fig. 2). In the 5.7-4 mm $(-2.5$ to $-2 \phi)$ fraction, there should be enough particles for study in many proximal to medial samples. A similar fraction was previously used by Ersoy et al. (2006).

\section{Detailed componentry of glassy juvenile particles (recommended)}

The main paper describes the standard basic componentry (separating grains from a size fraction into juvenile, lithic, \pm free crystal, \pm composite). Full componentry further distinguishes different types of glassy juvenile fragments, different types of lithics, crystals, etc., and is an option for all three size fractions. We specifically recommend detailed componentry on glassy juvenile fragments for the medium lapilli and coarse ash fractions (Fig. 2).

\section{Componentry classes}

In theory, juvenile clasts can be divided into primary and recycled (Houghton and Smith 1993; White and Houghton 2006; D'Oriano et al. 2014). Recycled clasts have fallen back into the crater and have then been ejected again (D'Oriano et al. 2014). Distinction between primary juvenile clasts and those recycled in this way can be very difficult, but where possible will help investigators distinguish the signatures of primary fragmentation from those of intra-crater recycling (D'Oriano et al. 2013, 2014; Deardorff and Cashman 2017).

In practice, different populations of glassy juvenile clasts can be distinguished based on their colors, lusters, clast shapes, vesicularities, vesicle sizes and shapes, crystallinities, degree of alteration, etc. (e.g., Taddeucci et al. 2002, 2004; Eychenne and Le Pennec 2012; Pardo Villaveces 2012; Suzuki et al. 2013; Andronico et al. 2014b; Cioni et al. 2014; D'Oriano et al. 2014; Eychenne et al. 2015; Gaunt et al. 2016; Liu et al. 2017). It does not appear possible to create a universal standardized scheme for detailed juvenile componentry, but workers should carefully define and illustrate their component classes in publications.

\section{How many grains?}

For component abundances of $10-20 \%$ or more, counting 200 particles is a reasonable compromise between precision and speed (see the paper, in particular Fig. 4c). If there is good reason to quantify components with low abundances $(<5 \%)$, larger numbers of clasts must be counted. For a component representing about $3-4 \%$ of a sample, a relative $2 \sigma$ error of $50 \%$ can be reached by counting 400-500 clasts (Fig. 4c). Such errors can be tolerated if different samples have marked differences in the abundances of these components. For comparison, Houghton and Carey (2015) mention that counting 200 clasts (from the bulk fraction) is 'typical' for each size fraction; Eychenne and Le Pennec (2012), Pardo et al. (2014b), Eychenne et al. (2015), Gaunt et al. (2016), Jones et al. (2016) and Ort et al. (2018) all counted 300 grains or more for each fraction; Andronico et al. (2009, 2014b), Jordan et al. (2016) and Scarpati et al. (2016) counted 500 clasts or more; Taddeucci and Palladino (2002) and Taddeucci et al. (2002) counted "more than 1000" particles per sample. The number of clasts to count depends on the focus of the study, and the abundance of constituents of interest.

In summary and as a general rule, we recommend counting $200+$ glassy juvenile grains to quantify the most abundant juvenile components (Fig. 2), and 400-500 grains if juvenile components with low abundances are to be studied. Even more grains are needed to be confident at the level of a percent or two. For the 5.7-4 mm ( -2.5 to $-2 \phi)$ fraction, these glassy juvenile grains can be counted by eye (Eychenne and Le Pennec 2012; Murch et al. 2019a) or under a binocular microscope (Ersoy et al. 
2006). For the $0.71-0.5 \mathrm{~mm}(+0.5$ to $+1 \phi)$ fraction, a binocular microscope is used. For both fractions, all glassy juvenile particles separated during basic componentry can first be classified, and then more can be separated from the remaining bulk fraction. If counting several hundred grains, the user can proceed in steps of 100 particles and compare the data between steps, to get an idea of the reproducibility of the results.

Juvenile particle selection and preparation for internal texture analysis (medium lapilli and coarse ash)

After detailed componentry of glassy juvenile particles, a subset is selected for mounting. For the medium lapilli fraction, $\sim 15-20$ representative particles are selected to make a polished thin section or polished epoxy grain mount, on which internal textures can be studied (Fig. 2). These lapilli should be well separated on the mount or thin section. For the coarse ash fraction, 50 representative juvenile particles are selected to manufacture a polished epoxy grain mount (Comida et al. 2022), to be used for morphological and textural measurements.

\section{Image analysis of cross-sectioned single particles (three fractions)}

The standard shape and textural parameters to measure on images of cross-sectioned particles of the coarse ash fraction are presented in the paper. Recommended and optional steps related to the cross-sections (obtained through polished epoxy grain mounts and/or polished thin sections) of the medium lapilli, coarse ash and very fine ash fractions are presented here.

Crystallinity and vesicularity for the medium lapilli fraction (recommended)

For the medium lapilli fraction, the recommended textural parameters are 2D vesicularity and 2D crystallinity (Fig. 2). These are measured exactly as described in the paper for the coarse ash fraction, using the PASTA code. We do not recommend measuring morphology parameters for the lapilli, since it may not give information on primary fragmentation due to factors such as relaxation, aerodynamic drag, and modification during transport (Manga et al. 2011), etc.

Other shape measurements for the coarse ash fraction (optional)

For the coarse ash fraction, based on the acquired SEM images of particle cross-sections, additional morphometric parameters and particle outline characteristics can be measured if the user wishes. This can be particularly useful for comparison with existing studies. This includes the parameters proposed by Cioni et al. (2014), Leibrandt and Le Pennec (2015) or Schmith et al. (2017), which are for example obtained using PARTISAN (Dürig et al. 2019).

Morphology and textural parameters for the very fine ash fraction (recommended)

The dual-mounting procedure for the very fine ash fraction produces a polished epoxy grain mount and SEM images of the same particles' cross-sections. In the figure 1 flowchart, this is used only for basic componentry, so in the paper, we state that the polishing can be done quickly and that a pixel density of 4000 or 5000 pixels per particle is enough. But the polished epoxy grain mount can also be used for morphology and textural characterization of this size fraction (recommended). In this case, grinding and polishing should be done very carefully to preserve the particle shapes, and SEM-BSE imaging should be done with a pixel resolution of at least 10000 pixels per particle (Comida et al. 2022). As for the coarse ash fraction, we suggest using PASTA and PARTISAN (see the paper) on images from the very fine ash fraction to obtain the same morphological and textural parameters.

\section{Internal textures: optional measurements}

A range of optional measurements are possible to further quantify the internal textures of juvenile pyroclasts, for the medium lapilli and coarse ash fractions. The size of each vesicle and crystal can be measured, to obtain the raw areal, or stereologically calculated volume, vesicle size distribution, vesicle number density, crystal size distribution, crystal number density, etc. (e.g., Mangan et al. 1993; Klug and Cashman 1994; Higgins 2000; Polacci et al. 2001; Taddeucci et al. 2004; Sable et al. 2006; Shea et al. 2010; Murtagh et al. 2011; Stovall et al. 2011, 2012; Murtagh and White 2013; Pardo et al. 2014b). The shapes of vesicles and crystals can also be quantified. These measurements can be done in FOAMS (http://www.soest.hawaii.edu/GG/FACULTY/tshea/foa ms/foamsintro.html), ImageJ and associated macros, or other image analysis software. The CSDslice database (Morgan and Jerram 2006) and software CSD corrections (Higgins 2000) allow researchers to obtain 3D crystal shapes, 3D crystallinities and associated crystal-size distributions. For crystals in particular, measurements can be facilitated if elemental phase maps are available from EDS chemistry (Hornby et al. 2019). Vesicle size distribution and crystal size distribution can yield important insights into vesicle/crystal nucleation/growth processes, from the magma reservoirs to the surface.

Textural examination of the groundmass of juvenile pyroclasts can also help determine whether reheating, related to hot-state recycling during the eruption, might have taken place (D’Oriano et al. 2013, 2014).

\section{Dual mounting for the very fine ash fraction}

In the figure 1 flowchart, for the very fine ash fraction, $200+$ particles are dual-mounted from the bulk fraction, including $100+$ glassy juvenile grains. In the figure 2 flowchart, more particles are needed, since we now need 200 glassy juvenile grains for the 3D morphological classification (described below). Thus, enough of the bulk fraction should be mounted to get this number of glassy juvenile particles.

\section{D morphological classification of the very fine ash fraction (recommended)}

The Fig. 2 flowchart calls for a step of 3D morphological classification of glassy juvenile grains from the very fine ash fraction. To clarify, the difference between 3D morphological classification and detailed componentry is that for the latter, glassy juvenile grains are classified according to all features observable by eye or with a 
binocular microscope, including shape but also color, luster, alteration, etc. (see above). Because very fine ash is studied using SEM images from the carbon tape grain mount, rather than a binocular microscope, 3D particle shapes become the main observable features for this fraction. Hence, for very fine ash, detailed componentry of glassy juvenile particles is replaced by 3D morphological classification. The qualitative 3D work adds information on the third dimension, relative to the standard morphology parameter measurements on silhouettes. For example it provides insights into if a circularly shaped particle (in 2D) is actually spherical or ovoid, or if an angular particle is blocky or plate-like.

The goal is to classify the glassy juvenile clasts into distinct classes or categories based on their overall 3D shapes (e.g., Heiken and Wohletz 1985; Cioni et al. 2008; Andronico et al. 2014b; Jordan et al. 2014; Comida et al. 2017; Murch et al. 2019a). This exercise is partly userdependent (i.e. subjective), but data from a single user should be internally consistent and should be very useful in comparing different samples. Fig. S1 shows typical particle shapes, for a range of magma compositions, vesicularities and fragmentation processes, to help users homogenize the way they classify particles. These SEM images are mostly for fine or very fine ash, but the same shape classes can also be applied to coarse ash.

\section{Fluidal particles}

A first group of particles, generally corresponding to the 'achneliths' of Walker and Croasdale (1971), has smooth surfaces influenced by surface tension. These fluidal particles might be variably vesicular inside (D'Oriano et al. 2011; Porritt et al. 2012; Pompilio et al. 2017; Clarke et al. 2019), but their external 'skin' tends to show few vesicles, except for the irregular variety. Particles of this group are generally thought to result from ductile (hydrodynamic) fragmentation of ultramafic to mafic magmas (Zimanowski et al. 2003; Stovall et al. 2011; Eychenne et al. 2015), although some felsic magmas can show fluidal behavior as well, suggesting anomalously low viscosity (Clarke et al. 2019; Murch et al. 2019b). Ductile fragmentation happens when the characteristic deformation times are greater than the viscous relaxation times (Zimanowski et al. 2003) and can be associated with a range of both magmatic and phreatomagmatic eruptive styles, in subaerial and submarine environments (e.g., Büttner et al. 2002; Dellino and Kyriakopoulos 2003; Stovall et al. 2011; Eychenne et al. 2015; Fitch et al. 2017; Murch et al. 2019a, 2019b; Dürig et al., 2020a, 2020b).

- Pele's hairs are "long thin strands" of glass (Heiken and Wohletz 1985), mostly with diameters of 1-300 $\mu \mathrm{m}$ (Duffield et al. 1977), or sometimes thicker (Cannata et al. 2019); their surfaces are smooth to ribbed (Heiken 1974) (Figs. S1a, S1b; for other examples, see Heiken 1974's plates $7 \mathrm{~g}$ and $13 \mathrm{~b}$ and Cannata et al. 2019's Fig. 1);
- Ovoid particles are lobate to ovoid in shape (Fig. S1c; ovoids are sometimes grouped with tears, e.g. Porritt et al. 2012);

- Pele's tears are "tear-shaped pendants of basaltic glass" (Heiken and Wohletz 1985) (Fig. S1d; for other examples, see Porritt et al. 2012's Fig. 3c);

- Spheres are smooth spherical particles (Fig. S1e) (for other examples, see Heiken 1974's plate 8a; Jordan et al. 2014's Fig. 3, $2^{\text {nd }}$ row);

- Fluidal-irregular particles have a smooth, largely continuous skin, but they are more irregular than the other types of fluidal particles, perhaps due to more visible vesicles. Also, not all of the particle surface necessarily needs to look fluidal for it to be classified this way (Murch et al. 2019a) (Fig. S1f; for other examples, see Heiken 1974's Plate 2a; Wohletz and Krinsley 1978's Fig. 1-8-3; Cioni et al. 2008's Fig. 4b top; D'Oriano et al. 2011's Fig. 2 left; Andronico et al. 2014b's Fig. 10a; Cioni et al. 2014's Fig. 3 bottom row; Murch et al. 2019a's Fig. 7g). The key feature is that at least part of the particle displays the continuous skin.

\section{Vesicle-dominated particles}

A second group of particles have shapes that are controlled by abundant broken vesicles, clearly visible on the particle exterior (Heiken 1974). We call this group "vesicle-dominated" because the bubbles control the overall particle shape and/or the details of the shape. These particles all lack the fluidal aspect (the smoothly curved 'skin') of the first group. This group includes (1) scoria, which is generally ultramafic to mafic; (2) pumice, which is generally intermediate to felsic (although 'pumice' has been used for highly vesicular clasts from basaltic lava fountains in Hawaii, i.e. golden pumice, and for some clasts from the Grímsvötn 2004 eruption in Iceland; Jude-Eton et al. 2012); (3) elongate/tubular particles, again typical of more evolved magmas; (4) vesicle walls/shards, the more finely fragmented version of the first three types; and (5) vesicular-irregular particles.

- Scoria has abundant vesicles with walls thicker than that of pumice (Heiken and Wohletz 1985); these fragments are sometimes called spongy (Fig. S1g; for other examples, see D'Oriano et al. 2011's Fig. 2 “spongy”; Cioni et al. 2011's Fig. 7 “spongy”);

- Pumice has very abundant vesicles with thin walls (Heiken and Wohletz 1985) (Fig. S1h; for other examples, see Heiken 1974's plate 20; D'Oriano et al. 2011's Fig. 2 right);

- Elongate-tubular particles contain very long vesicles, and are also known as tube, or woody (Allen et al. 2010), pumice (Fig. S1i; for other examples see Heiken 1974's plate 20; Cioni et al. 2011's Fig. 7 "tubular”; Murch et al. 2019a's Figs. 3c, 7k); 

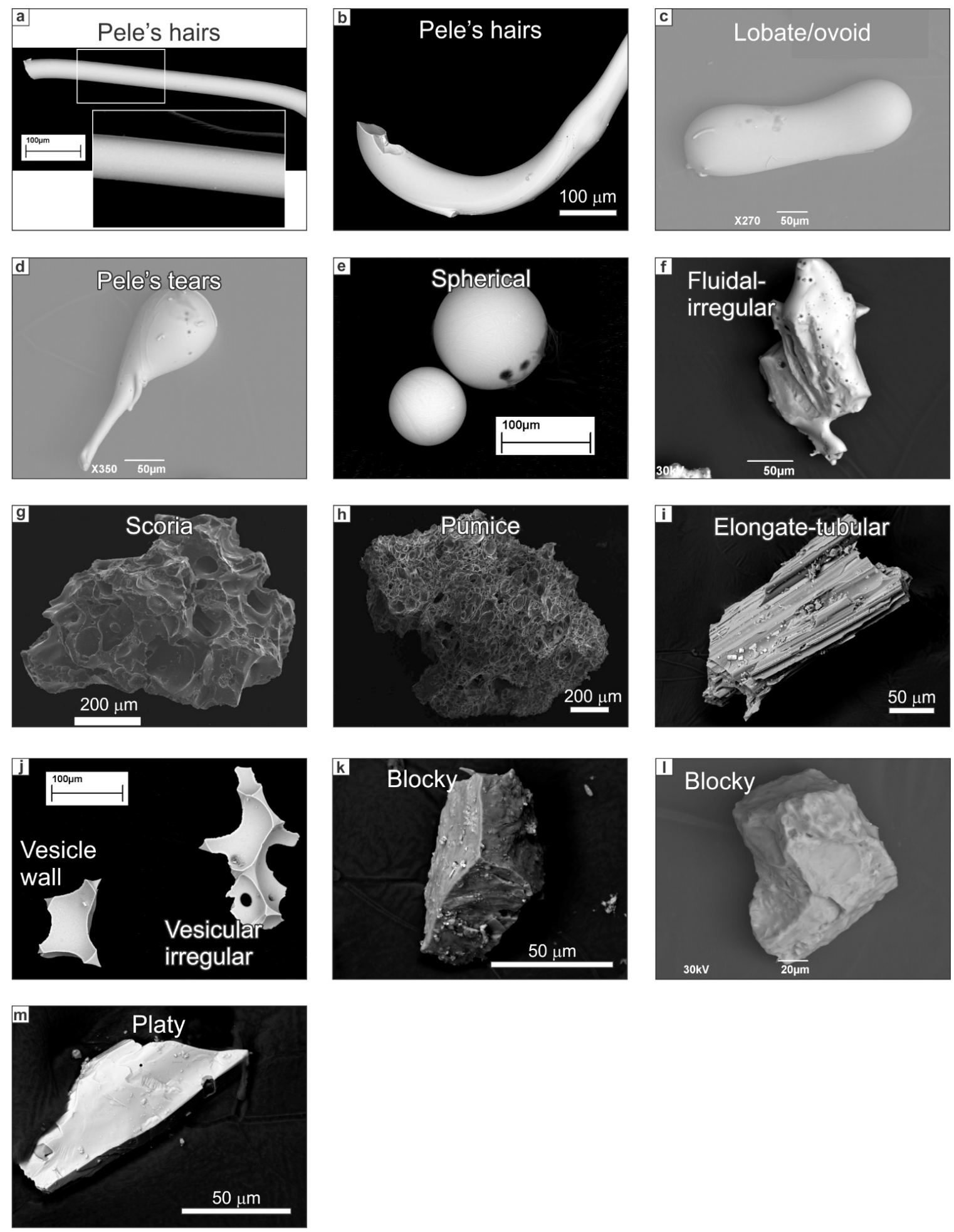

Fig. S1. SEM images of some typical 3D particle shapes, mostly in the fine or very fine ash ranges, from both natural juvenile pyroclasts and products of magma fragmentation experiments at the University of Würzburg: (a)-(f) fluidal group; (g)-(j) vesicle-dominated group; (k)-(m) angular group. (a)-(b) Pele's hairs generated in blowout experiments with mafic magma and intermediate magma, respectively. (c) Lobate/ovoid particle generated in a blowout experiment with ultramafic magma. (d) Pele's tear obtained during the same experiment as for (c). (e) Spherical particle generated in a blowout experiment with mafic magma. (f) Fluidal-irregular particle from the mafic eruption of the Ukinrek maars (Alaska) in 1977. (g) Andesitic scoria from the 2006 Tungurahua eruption (Ecuador). (h) Felsic pumice from the same eruption. (i) Elongate-tubular particle from the submarine felsic Havre eruption of 2012. (j) Vesicle wall and vesicularirregular particles from the Kilauea Iki (Hawaii) eruption of 1959 (mafic). (k) Blocky fragment from Havre (felsic). (l) Blocky fragment from Ukinrek (mafic). (m) Platy fragment from Havre (felsic). 
- Vesicle walls, also known as "bubble walls" or sometimes "glass shards", are "characterized by highly concave outlines with smooth surfaces from large bounding vesicles" (Liu et al. 2017) (Fig. S1j); this includes Y-shaped particles (for other examples see Murtagh and White 2013's Fig. 12a; Cashman and Rust 2016's Fig. 11h);

- Vesicular-irregular is a poorly defined category for vesicular grains that do not fit in the previous categories (Fig. S1j); this includes the "light-colored, glassy, vesicular particles with sub-spherical bubbles and irregular shape" described at Etna by Andronico et al. (2014b) as well as the "vesicular particles of irregular shapes" documented from Eyjafjallajökull by Dellino et al. (2012, see their Fig. 4e).

\section{Angular particles}

A third group consists of particles with angular shapes, such as blocky and platy grains. Archetypical blocky and platy clasts have a low vesicularity (Wohletz 1983), but this is not part of the definition here, although such clasts will be easier to recognize if their vesicularity is moderate or less. These particles are produced by brittle fragmentation of magma with any composition (Büttner et al. 2002; Dürig et al. 2012a, 2012b, 2020a, 2020b; Fitch et al. 2017; Murch et al. 2019a). Angular particles can be produced by a variety of eruptive processes, including hyaloclastite formation (thermal granulation), formation of blocky peperite, phreatomagmatic fragmentation, and some explosive magmatic styles such as dome-shattering Vulcanian blasts and basaltic activity at Etna ranging from "ash explosions" to strombolian activity (Skilling et al. 2002; Taddeucci et al. 2002, 2004; Dellino and Kyriakopoulos 2003; Andronico et al. 2009; Miwa et al. 2009; Dürig et al. 2012b, 2020a; Murtagh and White 2013; Polacci et al. 2019). Depending on the eruptive style and cooling rates, angular particles can have different internal textures; for example, in basalts, hyaloclastite should have glassy (sideromelane) textures (Schipper et al. 2011; White et al. 2015), phreatomagmatic particles can range from sideromelane to tachylite (Andronico et al. 2009), and blocky particles of magmatic origin at Etna are micro- to crypto-crystalline tachylite (Taddeucci et al. 2002, 2004; Polacci et al. 2019).

- Blocky particles are generally equant to subequant and feature "planar or curviplanar surfaces that intersect nearly at right angles" (Heiken and Wohletz 1985; Figs. S1k-1) (for other examples, see Heiken 1974's plates 23a and 25a; Wohletz and Krinsley 1978's Fig. 1-81; Taddeucci et al. 2004's Fig. 3 lower left; Cioni et al. 2008's Fig. 4c; Andronico et al. 2014b's Fig. 10c);

- $\quad$ Platy particles are similar to blocky ones, but are plate-like instead of equant or sub-equant. When their vesicularity is low, platy particles can have "smooth surfaces and angular contours" (Dürig et al. 2012b; Fig. S1m). Some small platy particles may represent bubble wall shards (Wohletz 1983; Cashman and Rust 2016) (for other examples, see Pardo Villaveces 2012's Fig. 4.9b; Dürig et al. 2012b's Fig. 5, $4^{\text {th }}$ row; Cashman and Rust 2016's Fig. 11h; Murch et al. 2019a's Fig. 7c).

\section{Practical details}

The paper describes basic componentry of the very fine ash fraction based on SEM images of the polished epoxy grain mount (Fig. 4e). For 3D morphological classification of glassy juvenile particles, the counting method is essentially the same (e.g., manual point counting in JMicroVision) except that SEM images from the carbon tape grain mount are used. Only the particles identified as glassy juvenile fragments on the polished epoxy grain mount should be utilized for the $3 \mathrm{D}$ morphology study.

\section{Quantitative shape analysis: alternative methods}

As mentioned in the paper, methods other than the SEM can also be used to measure particle shapes, including micro-CT and automated particle analyzers. The challenge is that raw shape factors measured by different methods cannot be directly compared at present. In the future, it might be possible to empirically 'correct' or 'calibrate' shape factors from different methods to make them comparable to a common standard.

\section{References cited}

Allen SR, Fiske RS, Tamura Y (2010) Effects of water depth on pumice formation in submarine domes at Sumisu, IzuBonin arc, western Pacific. Geology 38:391-394

Andronico D, Cristaldi A, Del Carlo P, Taddeucci J (2009) Shifting styles of basaltic explosive activity during the 2002-03 eruption of Mt. Etna, Italy. J. Volcanol. Geotherm. Res. 180:110-122

Andronico D, Scollo S, Cristaldi A, Lo Castro MD (2014a) Representivity of incompletely sampled fall deposits in estimating eruption source parameters: a test using the 12-13 January 2011 lava fountain deposit from Mt. Etna volcano, Italy. Bull. Volc. 76:article 861

Andronico D, Scollo S, Lo Castro MD, Cristaldi A, Lodato L, Taddeucci J (2014b) Eruption dynamics and tephra dispersal from the 24 November 2006 paroxysm at South-East Crater, Mt Etna, Italy. J. Volcanol. Geotherm. Res. 274:78-91

Bain AA, Kendrick JE, Lamur A, Lavallée Y, Calder ES, Cortés JA, Cortés GP, Gómez Martinez D, Torres RA (2021) Micro-textural controls on magma rheology and vulcanian explosion cyclicity. Front. Earth Sci. 8:611320

Bonadonna C, Houghton BF (2005) Total grain-size distribution and volume of tephra-fall deposits. Bull. Volc. 67:441-456

Bonadonna C, Genco R, Gouhier M, Pistolesi M, Cioni R, Alfano F, Hoskuldsson A, Ripepe M (2011) Tephra sedimentation during the 2010 Eyjafjallajökull eruption (Iceland) from deposit, radar, and satellite observations. J. Geophys. Res. Solid Earth 116(B12202)

Büttner R, Dellino P, La Volpe L, Lorenz V, Zimanowski B (2002) Thermohydraulic explosions in phreatomagmatic eruptions as evidenced by the comparison between pyroclasts and products from Molten Fuel Coolant Interaction experiments. J. Geophys. Res. 107:Art. 2277 
Cannata CB, De Rosa R, Donato P, Donato S, Lanzafame G, Mancini L, Houghton BF (2019) First 3D imaging characterization of Pele's hair from Kilauea volcano (Hawaii). Sci. Rep. 9:1711

Cashman K, Rust A (2016) Volcanic ash: Generation and spatial variations. In: Mackie S, Cashman K, Ricketts $\mathrm{H}$, Rust A, Watson M (eds) Volcanic Ash. Elsevier, pp 5-22

Cioni R, D'Oriano C, Bertagnini A (2008) Fingerprinting ash deposits of small scale eruptions by their physical and textural features. J. Volcanol. Geotherm. Res. $177: 277-287$

Cioni R, Bertagnini A, Andronico D, Cole PD, Mundula F (2011) The 512 AD eruption of Vesuvius: complex dynamics of a small scale subplinian event. Bull. Volc. 73:789-810

Cioni R, Pistolesi M, Bertagnini A, Bonadonna C, Hoskuldsson A, Scateni B (2014) Insights into the dynamics and evolution of the 2010 Eyjafjallajökull summit eruption (Iceland) provided by volcanic ash textures. Earth Planet. Sci. Lett. 394:111-123

Clarke B, Calder ES, Dessalegn F, Fontijn K, Cortés JA, Naylor M, Butler I, Hutchison W, Yirgu G (2019) Fluidal pyroclasts reveal the intensity of peralkaline rhyolite pumice cone eruptions. Nature Communications 10:article 2010

Colombier M, Wadsworth FB, Gurioli L, Scheu B, Kueppers U, Di Muro A, Dingwell DB (2017a) The evolution of pore connectivity in volcanic rocks. Earth Planet. Sci. Lett. 462:99-109

Colombier M, Gurioli L, Druitt TH, Shea T, Boivin P, Miallier D, Cluzel N (2017b) Textural evolution of magma during the 9.4-ka trachytic explosive eruption at Kilian Volcano, Chaîne des Puys, France. Bull. Volc. 79:article 17

Comida PP, Ross P-S, Zimanowski B, Büttner R (2017) Artificial juvenile pyroclasts from wet and dry "eruptions": impact of magma composition on grain sizes and particle shapes. IAVCEI 2017, Portland, Oregon, USA

Comida PP, Ross P-S, Dürig T, White JDL, Lefebvre N (2022) Standardized analysis of juvenile pyroclasts in comparative studies of primary magma fragmentation; 2. Choice of size fractions and method optimization. Bull. Volc.

Costa A, Pioli L, Bonadonna C (2016) Assessing tephra total grain-size distribution: Insights from field data analysis. Earth Planet. Sci. Lett. 443:90-107

Deardorff N, Cashman K (2017) Rapid crystallization during recycling of basaltic andesite tephra: timescales determined by reheating experiments. Sci. Rep. 7:1-8

Dellino P, La Volpe L (1995) Fragmentation versus transportation mechanisms in the pyroclastic sequence of Monte Pilato-Rocche Rosse (Lipari, Italy). J. Volcanol. Geotherm. Res. 64:211-231

Dellino P, Kyriakopoulos K (2003) Phreatomagmatic ash from the ongoing eruption of Etna reaching the Greek island of Cefalonia. J. Volcanol. Geotherm. Res. 126:341345

Dellino P, Gudmundsson MT, Larsen G, Mele D, Stevenson JA, Thordarson T, Zimanowski B (2012) Ash from the Eyjafjallajökull eruption (Iceland): Fragmentation processes and aerodynamic behavior. J. Geophys. Res. Solid Earth 117:B00C04

D’Oriano C, Bertagnini A, Pompilio M (2011) Ash erupted during normal activity at Stromboli (Aeolian Islands, Italy) raises questions on how the feeding system works. Bull. Volc. 73:471-477

D’Oriano C, Pompilio M, Bertagnini A, Cioni R, Pichavant M (2013) Effects of experimental reheating of natural basaltic ash at different temperatures and redox conditions. Contrib. Min. Pet. 165:863-883

D'Oriano C, Bertagnini A, Cioni R, Pompilio M (2014) Identifying recycled ash in basaltic eruptions. Scientific Reports 4:article 5851

Duffield WA, Gibson E, Heiken G (1977) Some characteristics of Pele's hair. J. Res. US Geol. Surv 5:93-10

Dürig T, Sonder I, Zimanowski B, Beyrichen H, Büttner R (2012a). Generation of volcanic ash by basaltic volcanism. J. Geophys. Res. 117, B01204.

Dürig T, Mele D, Dellino P, Zimanowski B (2012b) Comparative analyses of glass fragments from brittle fracture experiments and volcanic ash particles. Bull. Volc. 74:691-704

Dürig T, Bowman MH, White JDL, Murch A, Mele D, Verolino A, Dellino P (2019) PARTIcle Shape ANalyzer PARTISAN - an open source tool for multi-standard two-dimensional particle morphometry analysis. Annals of Geophysics 61: AC31, DOI:10.4401/ag7865

Dürig T, White JDL, Murch AP, Zimanowski B, Büttner R, Mele D, Dellino P, Carey RJ, Schmidt LS, Spitznagel N (2020a) Deep-sea eruptions boosted by induced fuelcoolant explosions. Nature Geosci. 13(7):498-503. DOI: $10.1038 / \mathrm{s} 41561-020-0603-4$

Dürig T, White JDL, Zimanowski B, Büttner R, Murch A, Carey RJ (2020b) Deep-sea fragmentation style of Havre revealed by dendrogrammatic analyses of particle morphometry. Bull. Volc. 82(10):67. DOI: 10.1007/s00445-020-01408-1

Ersoy O, Chinga G, Aydar E, Gourgaud A, Evren Cubukcu H, Ulusoy I (2006) Texture discrimination of volcanic ashes from different fragmentation mechanisms: A case study, Mount Nemrut stratovolcano, eastern Turkey. Computers \& Geosciences 32:936-946

Eychenne J, Le Pennec J-L (2012) Sigmoidal particle density distribution in a subplinian scoria fall deposit. Bull. Volc. 74:2243-2249

Eychenne J, Le Pennec J-L, Troncoso L, Gouhier M, Nedelec JM (2012) Causes and consequences of bimodal grainsize distribution of tephra fall deposited during the August 2006 Tungurahua eruption (Ecuador). Bull. Volc. 74:187-205

Eychenne J, Houghton BF, Swanson DA, Carey RJ, Swavely L (2015) Dynamics of an open basaltic magma system: The 2008 activity of the Halema'uma'u Overlook vent, Kīlauea Caldera. Earth Planet. Sci. Lett. 409:4960

Fitch EP, Fagents SA, Thordarson T, Hamilton CW (2017) Fragmentation mechanisms associated with explosive lava-water interactions in a lacustrine environment. Bull. Volc. 79:article 12

Formenti Y, Druitt T (2003) Vesicle connectivity in pyroclasts and implications for the fluidisation of fountaincollapse pyroclastic flows, Montserrat (West Indies). Earth and Planetary Science Letters, 214:561-574

Gardner JE, Thomas RME, Jaupart C, Tait S (1996) Fragmentation of magma during Plinian volcanic eruptions. Bull. Volc. 58:144-162

Gaunt HE, Bernard B, Hidalgo S, Proaño A, Wright H, Mothes P, Criollo E, Kueppers U (2016) Juvenile magma recognition and eruptive dynamics inferred from the analysis of ash time series: The 2015 reawakening of Cotopaxi volcano. J. Volcanol. Geotherm. Res. 328:134-146

Graettinger AH, Valentine GA, Sonder I, Ross P-S, White JDL (2015) Facies distribution of ejecta in analog tephra rings from experiments with single and multiple subsurface explosions. Bull. Volc. 77:Article 66 
Gurioli L, Andronico D, Bachelery P, Balcone-Boissard H, Battaglia J, Boudon G, Burgisser A, Burton MR, Cashman K, Cichy S, Cioni R, et al. (2015) MeMoVolc consensual document: a review of crossdisciplinary approaches to characterizing small explosive magmatic eruptions. Bull. Volc. 77:49

Gurioli L, Di Muro A, Vlastélic I, Moune S, Thivet S, et al. (2018) Integrating field, textural, and geochemical monitoring to track eruption triggers and dynamics: a case study from Piton de la Fournaise. Solid Earth 9:431-455

Heiken G (1974) An atlas of volcanic ash. Smithsonian Contributions to the Earth Sciences 12, Washington, $101 \mathrm{p}$

Heiken G, Wohletz K (1985) Volcanic ash. University of California Press, Berkeley, California, 246 p.

Higgins MD (2000) Measurement of crystal size distributions. American Mineralogist 85:1105-1116

Hornby AJ, Lavallée Y, Kendrick JE, Rollinson G, Butcher AR, Clesham S, Kueppers U, Cimarelli C, Chigna G (2019) Phase partitioning during fragmentation revealed by QEMSCAN Particle Mineralogical Analysis of volcanic ash. Scientific Reports 9:126

Houghton B, Wilson CJN (1989) A vesicularity index for pyroclastic deposits. Bull. Volc. 51:451-462

Houghton BF, Smith RT (1993) Recycling of magmatic clasts during explosive eruptions: estimating the true juvenile content of phreatomagmatic volcanic deposits. Bull. Volc. 55:414-420

Houghton B, Carey RJ (2015) Pyroclastic fall deposits. In: Sigurdsson H, Houghton B, McNutt SR, Rymer H, Stix J (eds) The Encyclopedia of Volcanoes, Second Edition. Academic Press, London, pp 599-616

Jones TJ, McNamara K, Eychenne J, Rust AC, Cashman KV, Scheu B, Edwards R (2016) Primary and secondary fragmentation of crystal-bearing intermediate magma. J. Volcanol. Geotherm. Res. 327:70-83

Jordan SC, Dürig T, Cas RAF, Zimanowski B (2014) Processes controlling the shape of ash particles: Results of statistical IPA. J. Volcanol. Geotherm. Res. 288:19-27

Jordan SC, Le Pennec JL, Gurioli L, Roche O, Boivin P (2016) Highly explosive eruption of the monogenetic $8.6 \mathrm{ka}$ BP La Vache et Lassolas scoria cone complex (Chaîne des Puys, France). J. Volcanol. Geotherm. Res. 313:15-28

Jude-Eton TC, Thordarson T, Gudmundsson MT, Oddsson B (2012) Dynamics, stratigraphy and proximal dispersal of supraglacial tephra during the ice-confined 2004 eruption at Grímsvötn Volcano, Iceland. Bull Volcanol 74:1057-1082

Kawabata, E, Cronin SJ, Bebbington MS, Moufti MRH, ElMasry N, Wang T (2015) Identifying multiple eruption phases from a compound tephra blanket: an example of the AD1256 Al-Madinah eruption, Saudi Arabia. Bulletin of Volcanology 77:article 6.

Klug C, Cashman KV (1994) Vesiculation of May 18, 1980 , Mount St. Helens magma. Geology 22:468-472

Leibrandt S, Le Pennec J-L (2015) Towards fast and routine analyses of volcanic ash morphometry for eruption surveillance applications. J. Volcanol. Geotherm. Res. 297:11-27

Liu EJ, Cashman KV, Rust AC, Höskuldsson A (2017) Contrasting mechanisms of magma fragmentation during coeval magmatic and hydromagmatic activity: the Hverfjall Fires fissure eruption, Iceland. Bull. Volc. 79:68

Manga M, Patel A, Dufek J (2011) Rounding of pumice clasts during transport: field measurements and laboratory studies. Bull. Volc. 73:321-333
Mangan MT, Cashman KV, Newman S (1993) Vesiculation of basaltic magma during eruption. Geology 21:157-160

Manville V, Segschneider B, White JDL (2002) Hydrodynamic behaviour of Taupo 1800a pumice:

Miwa T, Toramaru A, Iguchi M (2009) Correlations of volcanic ash texture with explosion earthquakes from vulcanian eruptions at Sakurajima volcano, Japan. J. Volcanol. Geotherm. Res. 184:473-486

Morgan DJ, Jerram DA (2006) On estimating crystal shape for crystal size distribution analysis. J. Volcanol. Geotherm. Res. 154:1-7

Murch AP, White JDL, Carey RJ (2019a) Characteristics and deposit stratigraphy of submarine-erupted silicic ash, Havre Volcano, Kermadec arc, New Zealand. Frontiers in Earth Science 7:article 1

Murch AP, White JDL, Carey RJ (2019b) Unusual fluidal behavior of a silicic magma during fragmentation in a deep subaqueous eruption, Havre volcano, southwestern Pacific Ocean. Geology 47:487-490

Murtagh RM, White JDL, Sohn YK (2011) Pyroclast textures of the Ilchulbong 'wet' tuff cone, Jeju Island, South Korea. J. Volcanol. Geotherm. Res. 201:385-396

Murtagh RM, White JDL (2013) Pyroclast characteristics of a subaqueous to emergent Surtseyan eruption, Black Point volcano, California. J. Volcanol. Geotherm. Res. 267:75-91

Ort MH, Lefebvre NS, Neal CA, McConnell VS, Wohletz KH (2018) Linking the Ukinrek 1977 maar-eruption observations to the tephra deposits: New insights into maar depositional processes. J. Volcanol. Geotherm. Res. 360:36-60

Pardo Villaveces N (2012) Andesitic Plinian eruptions at Mt. Ruapehu (New Zealand): from lithofacies to eruption dynamics. PhD thesis, Massey University, New Zealand

Pardo N, Cronin SJ, Németh K, Brenna M, Schipper CI, Breard E, White JDL, Procter J, Stewart B, Agustín-Flores J, Moebis A, Zernack A, Kereszturi G, Lube G, Auer A, Neall V, Wallace C (2014a) Perils in distinguishing phreatic from phreatomagmatic ash; insights into the eruption mechanisms of the 6 August $2012 \mathrm{Mt}$. Tongariro eruption, New Zealand. J. Volcanol. Geotherm. Res. 286:397-414

Pardo N, Cronin SJ, Wright HMN, Schipper CI, Smith I, Stewart B (2014b) Pyroclast textural variation as an indicator of eruption column steadiness in andesitic Plinian eruptions at Mt. Ruapehu. Bull. Volc. 76:822

Pioli L, Bonadonna C, Pistolesi M (2019) Reliability of total grain-size distribution of tephra deposits. Scientific Reports 9:article 10006

Polacci M, Papale P, Rosi M (2001) Textural heterogeneities in pumices from the climactic eruption of Mount Pinatubo, 15 June 1991, and implications for magma ascent dynamics. Bull. Volc. 63:83-97

Polacci M, Andronico D, de' Michieli Vitturi M, Taddeucci J, Cristaldi A (2019) Mechanisms of ash generation at basaltic volcanoes: the case of Mount Etna, Italy. Frontiers in Earth Science 7:article 193

Pompilio M, Bertagnini A, Del Carlo P, Di Roberto A (2017) Magma dynamics within a basaltic conduit revealed by textural and compositional features of erupted ash: the December 2015 Mt. Etna paroxysms. Scientific Reports 7:4805

Porritt LA, Russell JK, Quane SL (2012) Pele's tears and spheres: examples from Kilauea Iki. Earth Planet. Sci. Lett. 333:171-180

Sable JE, Houghton BF, Del Carlo P, Coltelli M (2006) Changing conditions of magma ascent and fragmentation during the Etna $122 \mathrm{BC}$ basaltic Plinian 
eruption: Evidence from clast microtextures. J. Volcanol. Geotherm. Res. 158:333-354

Scarpati C, Sparice D, Perrotta A (2016) Comparative proximal features of the main Plinian deposits (Campanian Ignimbrite and Pomici di Base) of Campi Flegrei and Vesuvius. J. Volcanol. Geotherm. Res. 321:149-157

Schipper CI, White JDL, Zimanowski B, Büttner R, Sonder I, Schmid A (2011) Experimental interaction of magma and "dirty" coolants. Earth Planet. Sci. Lett. 303:323336

Schmith J, Höskuldsson Á, Holm PM (2017) Grain shape of basaltic ash populations: implications for fragmentation. Bull. Volc. 79:article 14

Shea T, Houghton BF, Gurioli L, Cashman KV, Hammer JE, Hobden BJ (2010) Textural studies of vesicles in volcanic rocks: an integrated methodology. J. Volcanol. Geotherm. Res. 190:271-289

Skilling IP, White JDL, McPhie J (2002) Peperite: a review of magma-sediment mingling. J. Volcanol. Geotherm. Res. 114:1-17

Stovall WK, Houghton BF, Gonnermann H, Fagents SA, Swanson DA (2011) Eruption dynamics of Hawaiianstyle fountains: the case study of episode 1 of the Kīlauea Iki 1959 eruption. Bull. Volc. 73:511-529

Stovall W, Houghton B, Hammer J, Fagents S, Swanson D (2012) Vesiculation of high fountaining Hawaiian eruptions: episodes 15 and 16 of 1959 Kîlauea Iki. Bull. Volc. 74:441-455

Suzuki Y, Nagai M, Maeno F, Yasuda A, Hokanishi N, Shimano T, Ichihara M, Kaneko T, Nakada S (2013) Precursory activity and evolution of the 2011 eruption of Shinmoe-dake in Kirishima volcano - insights from ash samples. Earth, Planets and Space 65:11

Taddeucci J, Palladino DM (2002) Particle size-density relationships in pyroclastic deposits: inferences for emplacement processes. Bull. Volc. 64:273-284
Taddeucci J, Pompilio M, Scarlato P (2002) Monitoring the explosive activity of the July-August 2001 eruption of Mt. Etna (Italy) by ash characterization. Geophys. Res. Lett. 29:71-71-71-74

Taddeucci J, Pompilio M, Scarlato P (2004) Conduit processes during the July-August 2001 explosive activity of Mt. Etna (Italy): inferences from glass chemistry and crystal size distribution of ash particles. J. Volcanol. Geotherm. Res. 137:33-54

Thivet S, Gurioli L, Di Muro A, et al. (2020a) Evidences of plug pressurization enhancing magma fragmentation during the September 2016 basaltic eruption at Piton de la Fournaise (La Réunion Island, France). Geochemistry, Geophysics, Geosystems 21:1-30

Thivet S, Gurioli L, Di Muro A (2020b) Basaltic dyke eruptions at Piton de La Fournaise: characterization of the eruptive products with implications for reservoir conditions, conduit processes and eruptive dynamics. Contrib. Mineral. Petrol. 175:article 26

Walker GPL, Croasdale R (1971) Characteristics of some basaltic pyroclastics. Bull. Volc. 35:303-317

White JDL, Houghton BF (2006) Primary volcaniclastic rocks. Geology 34:677-680

White JDL, McPhie J, Soule SA (2015) Submarine lavas and hyaloclastite. In: Sigurdsson H, Houghton B, McNutt SR, Rymer H, Stix J (eds) Encyclopedia of Volcanoes, Second edition. Academic Press, London, pp. 363-375

Wohletz KH (1983) Mechanisms of hydrovolcanic pyroclast formation: grain-size, scanning electron microscopy, and experimental studies. J. Volcanol. Geotherm. Res. 17:31-63

Wohletz K, Krinsley D (1978) Scanning electron microscopy of basaltic hydromagmatic ash. Los Alamos National Laboratory, report LA-UR-82-1433

Zimanowski B, Wohletz K, Dellino P, Büttner R (2003) The volcanic ash problem. J. Volcanol. Geotherm. Res. $122: 1-5$ 


\section{Online resource 2: Excel templates}

To download Excel templates showing typical outputs of the standardized methodology, see the online version of the article on the journal website, or contact the corresponding author. 


\section{Online resource 3: Sieving of pyroclastic deposits}

Sieving is standard in the workflows. Pyroclastic deposits require more care than 'normal' sediments when sieving, so we present recommendations for best practices here.

\section{Blocks and bombs}

For very coarse pyroclastic deposits containing blocks and bombs, some of the grainsize analysis must be done in the field, by measuring individual fragments, by using coarse sieves in the field (Cas and Wright 1987; Bernard et al. 2014; Houghton and Carey 2015; Scarpati et al. 2016) or from photos of the outcrops (Gurioli et al. 2012; Bernard et al. 2014). Lapilli and ash (see Table 1 in the paper for grain size terms) are then taken back to the laboratory for further analysis.

One obvious advantage of dealing with blocks and bombs (and perhaps even some lapilli) in the field is to reduce sample weight for transportation back to the laboratory. A more subtle advantage is that eliminating the largest clasts before shipping may reduce secondary breakage during transport (E.P. Fitch, written commun., 2021).

\section{Drying and splitting}

In the laboratory, samples are first dried in an oven, typically at $105^{\circ} \mathrm{C}$ for up to 48 hours (Carter and Gregorich 2008). Then the sample is split (e.g., Andronico et al. 2014) until the starting mass is $500 \mathrm{~g}$ or less, to prevent clogging the sieves. For the ash fraction, we recommended to sieve no more than 50-100 g.

\section{Manual dry sieving}

Sieving can be destructive, especially for vesicular clasts and for particles with complex or elongate shapes. Gentle manual dry sieving is the least disruptive technique (e.g., Walker 1971; Barberi et al. 1989; Dellino and La Volpe 1995; Parfitt 1998; Gaunt et al. 2016; Avery et al. 2017; Liu et al. 2017; Schmith et al. 2018; Murch et al. 2019), and motorized sieve shakers should be avoided.

Half- $\phi$ sieves (Table 1) give more detailed grain size information than full- $\phi$ sieves, and half- $\phi$ size fractions are easier to mount in epoxy and polish to the middle of grains. But we again stress that manual sieving must be done very gently to minimize breakage and potential morphological modification. More work is needed to check the impact of various sieving techniques on breakage and particle morphologies.

The manual sieving procedure is typically as follows. Use one sieve at a time (i.e. one sieve plus the pan), down to $2 \mathrm{~mm}(-1 \phi)$, for no more than three minutes, to minimize breakage (Jordan et al. 2016). This can be continued down to $63 \mu \mathrm{m}(+4 \phi)$. Alternatively, the $2 \mathrm{~mm}(-1 \phi)$ to $63 \mu \mathrm{m}$ $(+4 \phi)$ sieves can be used as a column (Fig. S3a).

\section{Cleaning the sieves}

To minimize cross-contamination between samples, sieves should be carefully cleaned using either high pressure air and picks and/or by ultrasonic cleaning in distilled water (with ultrasonic soap) for sieves in the $0.5 \mathrm{~mm}(+1 \phi)$ to $63 \mu \mathrm{m}(+4 \phi)$ range (Merkus 2009) (Fig. $\mathrm{S} 3 \mathrm{~b}$ ). Alternatively, disposable sieve meshes can be used for the fine sieves (Liu et al. 2017), if the budget allows.
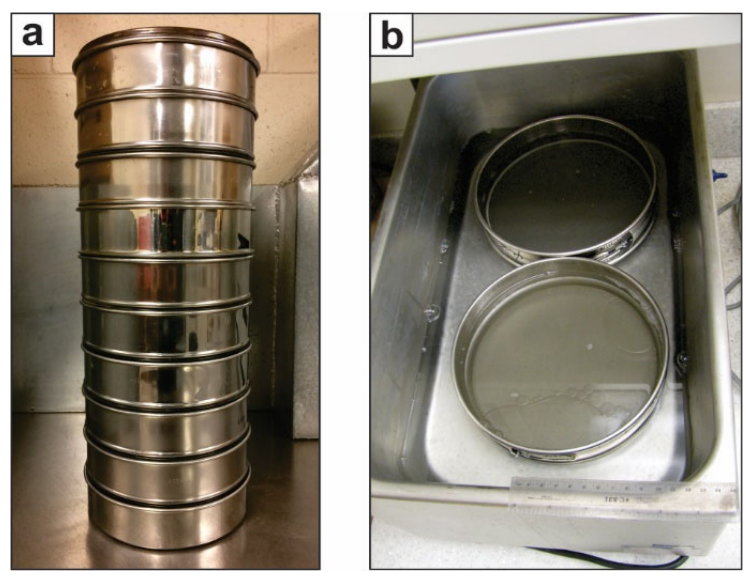

Fig. S3. Sieving and cleaning the sieves. (a) Column of full- $\phi$ sieves from $-4 \phi$ to $+4 \phi$. A column of half- $\phi$ sieves will yield a more detailed grainsize distribution. (b) Cleaning the finer sieves in an ultrasonic bath, after each sample is sieved.

\section{Dealing with aggregates}

Particle aggregates (e.g. armored and accretionary lapilli, or aggregates formed during sample drying) are problematic for fragmentation studies. These aggregates mask the properties of the constituent ash particles. One option to retrieve the individual ash particles is to attempt disaggregation in an ultrasonic bath with distilled water (not acid, see Cioni et al. 1992). Sodium hexametaphosphate, a deflocculant commonly used for microfossil preparation, can be useful (Casalbore et al. 2010). The sample can then be dried in an oven at $\sim 60^{\circ} \mathrm{C}$, checked under a binocular stereo microscope, and resieved. This process can be repeated until disaggregation is complete, noting that non-destructive separation of highly cemented aggregates may not be achievable.

\section{References cited}

Andronico D, Scollo S, Cristaldi A, Lo Castro MD (2014) Representivity of incompletely sampled fall deposits in estimating eruption source parameters: a test using the 12-13 January 2011 lava fountain deposit from Mt. Etna volcano, Italy. Bull. Volc. 76:article 861

Avery MR, Panter KS, Gorsevski PV (2017) Distinguishing styles of explosive eruptions at Erebus, Redoubt and Taupo volcanoes using multivariate analysis of ash morphometrics. J. Volcanol. Geotherm. Res. 332:1-13 
Barberi F, Cioni R, Rosi M, Santacroce R, Sbrana A, Vecci R (1989) Magmatic and phreatomagmatic phases in explosive eruptions of Vesuvius as deduced by grainsize and component analysis of the pyroclastic deposits. J. Volcanol. Geotherm. Res. 38:287-307

Bernard J, Kelfoun K, Le Pennec JL, Vallejo Vargas S (2014) Pyroclastic flow erosion and bulking processes: comparing field-based vs. modeling results at Tungurahua volcano, Ecuador. Bull. Volc. 76:article 858

Casalbore D, Romagnoli C, Chiocci F, Frezza V (2010) Morpho-sedimentary characteristics of the volcaniclastic apron around Stromboli volcano (Italy). Marine Geology 269:132-148

Carter MR, Gregorich EG (2008) Soil sampling and methods of analysis, second edition. Canadian Society of Soil Science, Taylor \& Francis Group

Cas RAF, Wright JV (1987) Volcanic successions, modern and ancient. Allen \& Unwin, London, $528 \mathrm{p}$.

Cioni R, Sbrana A, Vecci R (1992) Morphologic features of juvenile pyroclasts from magmatic and phreatomagmatic deposits of Vesuvius. J. Volcanol. Geotherm. Res. 51:61-78

Dellino P, La Volpe L (1995) Fragmentation versus transportation mechanisms in the pyroclastic sequence of Monte Pilato-Rocche Rosse (Lipari, Italy). J. Volcanol. Geotherm. Res. 64:211-231

Gaunt HE, Bernard B, Hidalgo S, Proaño A, Wright H, Mothes P, Criollo E, Kueppers U (2016) Juvenile magma recognition and eruptive dynamics inferred from the analysis of ash time series: The 2015 reawakening of Cotopaxi volcano. J. Volcanol. Geotherm. Res. 328:134-146

Gurioli L, Zanella E, Gioncada A, Sbrana A (2012) The historic magmatic-hydrothermal eruption of the Breccia di Commenda, Vulcano, Italy. Bull. Volc. 74:235-1254
Houghton B, Carey RJ (2015) Pyroclastic fall deposits. In: Sigurdsson H, Houghton B, McNutt SR, Rymer H, Stix $\mathrm{J}$ (eds) The Encyclopedia of Volcanoes, Second Edition. Academic Press, London, pp 599-616

Jordan SC, Le Pennec JL, Gurioli L, Roche O, Boivin P (2016) Highly explosive eruption of the monogenetic $8.6 \mathrm{ka} \mathrm{BP}$ La Vache et Lassolas scoria cone complex (Chaîne des Puys, France). J. Volcanol. Geotherm. Res. 313:15-28

Liu EJ, Cashman KV, Rust AC, Höskuldsson A (2017) Contrasting mechanisms of magma fragmentation during coeval magmatic and hydromagmatic activity: the Hverfjall Fires fissure eruption, Iceland. Bull. Volc. 79:68

Merkus HG (2009) Sieves and sieving. In: Particle size measurements - fundamentals, practice, quality. Springer, pp 219-240

Murch AP, White JDL, Carey RJ (2019) Characteristics and deposit stratigraphy of submarine-erupted silicic ash, Havre Volcano, Kermadec arc, New Zealand. Frontiers in Earth Science 7:article 1

Parfitt EA (1998) A study of clast size distribution, ash deposition and fragmentation in a Hawaiian-style volcanic eruption. J. Volcanol. Geotherm. Res. 84:197208

Scarpati C, Sparice D, Perrotta A (2016) Comparative proximal features of the main Plinian deposits (Campanian Ignimbrite and Pomici di Base) of Campi Flegrei and Vesuvius. J. Volcanol. Geotherm. Res. 321:149-157

Schmith J, Höskuldsson Á, Holm PM, Larsen G (2018) Large explosive basaltic eruptions at Katla volcano, Iceland: Fragmentation, grain size and eruption dynamics. J. Volcanol. Geotherm. Res. 354:140-152

Walker GPL (1971) Grain-size characteristics of pyroclastic deposits. J. Geol. 79:696-714 


\section{Online resource 4: Dual mounting of the very fine ash fraction}

\section{Carbon tape grain mount}

For the $88-63 \mu \mathrm{m}(+3.5$ to $+4 \phi)$ fraction, a carbon tape grain mount (CTGM) is the first stage of the dual mounting procedure (Fig. 1 in the paper). For preparing this CTGM, we offer four particle transfer methods: three quick ones and a slow one.

\section{Preparing the mounting surface}

All methods start with a circular double-sided carbon tape being stuck onto an aluminum disk (Fig. 5a in the paper). The top will be covered by a non-stick paper circle, on which a smaller circle is drawn, corresponding to the internal diameter of the ring form to be used later for the polished epoxy grain mount (Fig. 5b). This ensures that there will be no particles mounted near the periphery of the carbon tape later. The non-stick paper circle is then peeled off from the carbon tape (Fig. 5c).

\section{Quick particle transfer methods}

In the three quick methods, the marked non-stick paper circle is placed at the bottom of a petri dish, and a subsample from the bulk size fraction is spread evenly over it. The distribution of particles can be quickly evened out under the binocular microscope, using a fine brush or a needle. This is the point where the three quick methods differ. In the first one, the sticky (carbon tape) side of the aluminum disc is very gently pressed on the sample (Fig. $5 \mathrm{~d})$. The disk is then turned back upright and the paper circle taken off. There may be some particles touching each other, which is a nuisance when performing image analysis, but they can be separated manually with image editing software. It may be prudent to mount more than the minimum number of grains if using this method, to make sure that there are enough non-overlapping grains to work with.

In the second quick method, a moistened thumb (big finger) is used to transfer the particles from the non-stick circle to the sticky side of the carbon tape, making sure to press down very gently to avoid crushing fragile grains. The gesture can be repeated twice on the same position to get a concentrated mount, or applied on adjacent areas of the carbon tape (Fig. 5e). Wearing a latex/nitrile glove will prevent finger marks to be left on the tape.

The third quick method involves a fine-tipped paintbrush (E.P. Fitch, written commun., 2021). The paintbrush bristles are cut at a slight angle, so that grains can be easily picked up from the petri dish. The grains are then deposited on the carbon tape "with a gentle angled press of the paintbrush (...) along the cut edge". The maneuver is repeated a few times, until enough grains have been transferred. It is important to clean the brush thoroughly to avoid contamination between samples. This involves "tapping it over a trash can, with occasional blowing", and then the cleanliness of the brush is checked under the binocular microscope.

\section{Grain-by-grain transfer method}

For the slow method, particles are transferred and deposited one by one onto the carbon tape, under the binocular microscope. The transfer can be done with a metallic probe or a wooden toothpick. Moistening the tool with water can help. This method is ideal to get good particle separation but still mount the particles in a restricted area, which allows fewer SEM images for the same number of grains.

\section{Final steps}

With all mounting methods, a linear object with a thickness of $\sim 50 \mu \mathrm{m}$ or more is added to the carbon tape grain mount, to be used as a "horizontal" reference later, during imaging. For example, a long prism of cork, which can be cut with a sharp knife, has been trialed successfully (Fig. 5e). Finally, the CTGM is coated with a very thin layer of carbon or gold, under a vacuum. It is then ready to take to the SEM to image particles (Fig. 5f).

\section{Polished epoxy grain mount}

After SEM imaging of 3D grains at the SEM, the CTGM can be transformed into a polished epoxy grain mount (PEGM). This is the second stage of the dual mounting procedure for the very fine ash fraction.

First, the plastic ring form is glued on the side where particles are present (the carbon tape should still be sticky enough to do this). This ring form should have the same external diameter as the aluminum stub. Then the epoxy is poured (Fig. $5 \mathrm{~g}$ ). It is important to apply a lot of weight on top of the ring form during curing to make sure that epoxy does not penetrate under it. After curing, the assembly can be turned upside down (Fig. 5h). The aluminum stub and carbon tape are detached (Fig. 5i). This may leave a residue, which can be cleaned off with a soft paper tissue moistened with acetone. The epoxy mount is then ready for grinding and polishing, the aim being to expose the center of the smallest particle, which means removing $32 \mu \mathrm{m}$ of ring form, epoxy and particles. Detailed instructions on this portion of the procedure are available in Comida et al. (2022). (Note that for the Fig. 1 flowchart, the polishing does not have to be extremely careful for this particular mount, since only the inside of the particles will be studied, not the outlines, as opposed to the mount of the coarse ash fraction.) This leaves a finished polished epoxy grain mount, which can be coated with carbon (Fig. 5j) and taken back to the SEM for imaging (Fig. 5k). The raw SEM images of the polished grain mount should constitute mirror images of the carbon tape grain mount. 


\section{Online resource 5: SEM imaging settings}

\section{Coarse ash fraction}

For the polished epoxy grain mount of the 0.71-0.5 mm $(+0.5$ to $+1 \phi)$ fraction, the SEM is used in backscatter mode. Each particle must contain about 20000 pixels (see the paper and Comida et al. 2022). The following settings have been successfully employed at INRS to obtain 20000 pixels per particle: $68 \times$ magnification, $2048 \times 1536$ image resolution. Any combination of magnification and resolution that yields 20000 pixels per particle is acceptable.

Greyscales for glass, crystals, etc. should be consistent between images within the same sample. Any autobrightness/contrast function should be disabled so that brightness/contrast are unchanged from image to the next. Any drift in grey levels over time can be compensated by keeping the first image of a sample opened for reference.

Another important factor is the SEM scan speed, which must be set to produce high-quality images, even though this increases acquisition time, in order to optimize the contrast of the image and be able to distinguish small features such as microlites.

\section{Very fine ash fraction}

For the $88-63 \mu \mathrm{m}(+3.5$ to $+4 \phi)$ fraction, there is a dual mounting procedure (see the paper). This means that each mount is imaged twice: once as a carbon tape grain mount (CTGM), and later as a polished epoxy grain mount (PEGM). The backscatter mode of the SEM can be employed in both states.

If following only the standard steps (Fig. 1 in the paper), more pixels per particle are required in the CTGM state, to allow identification of interactive particles (see the paper). For example, 450x magnification and 2048x1556 resolution yields $\sim 16000$ pixels per particle in the CTGM state.

Then in the PEMG state, the same magnification should be used to produce a mirror image, but a lower resolution is acceptable to save time, since the only aim is basic componentry (and juvenile identification) in the flowchart with only the standard steps. For the 450x magnification mentioned above, $1024 \times 768$ resolution yields $\sim 4000$ pixels per particle for the PEGM. 